UC-70B

Issued: March 1986

LA- - 10449-MS

DE86 009797

\title{
Subsurface Moisture Regimes and Tracer Movement \\ Under Two Types of Trench-Cap Designs for Shallow Land Burial Sites
}

\author{
B. A. Perkins \\ E. J. Cokal
}

1

\section{DISCLAIMER}

This report was prepared as an account of work sponsored by an agency of the United States Guvernmer t. Neither the United States Government nor any agency thereof, nor any of their employees, makes any warranty, express or implied, or assumes any legal liability or responsibility for the accuracy, completeness, or usefulness of any information, apparatus, product, or process disclosed, or represents that its use would not infringe privately owned rights. Reference herein to any specific commercial product, process, or service by trade name, trademark, manufacturer, or otherwise does not necessarily constitute or imply its endorsement, recommendation, or favoring by the United States Government or any agency thereof. The views and opinions of authors expressed herein do not necessarily state or reflect those of the United States Government or any agency thereof. 


\section{CONTENTS}

ABSTRACT $\ldots \ldots \ldots \ldots \ldots \ldots \ldots \ldots \ldots \ldots \ldots \ldots \ldots \ldots \ldots \ldots \ldots \ldots \ldots \ldots \ldots \ldots \ldots \ldots \ldots \ldots$

I. INTRODUCTION $\ldots \ldots \ldots \ldots \ldots \ldots \ldots \ldots \ldots \ldots \ldots \ldots \ldots \ldots \ldots \ldots \ldots \ldots \ldots \ldots \ldots \ldots \ldots . \ldots \ldots$

II $\quad$ EMPLACEMENT $\ldots \ldots \ldots \ldots \ldots \ldots \ldots \ldots \ldots \ldots \ldots \ldots \ldots \ldots \ldots \ldots \ldots \ldots \ldots \ldots \ldots \ldots \ldots \ldots$

III. TECHNIQUES $\ldots \ldots \ldots \ldots \ldots \ldots \ldots \ldots \ldots \ldots \ldots \ldots \ldots \ldots \ldots \ldots \ldots \ldots \ldots \ldots \ldots \ldots \ldots \ldots . \ldots \ldots$

A. Precipitation $\ldots \ldots \ldots \ldots \ldots \ldots \ldots \ldots \ldots \ldots \ldots \ldots \ldots \ldots \ldots \ldots \ldots \ldots \ldots \ldots . \ldots \ldots$

B. Soil Moisture ..................................... 6

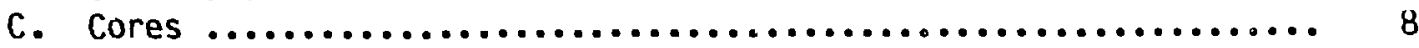

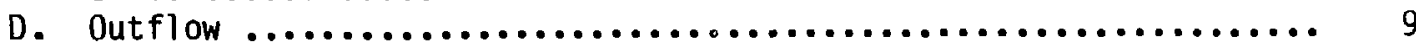

IV. DATA $\ldots \ldots \ldots \ldots \ldots \ldots \ldots \ldots \ldots \ldots \ldots \ldots \ldots \ldots \ldots \ldots \ldots \ldots \ldots \ldots \ldots \ldots \ldots \ldots \ldots \ldots \ldots . . \ldots$

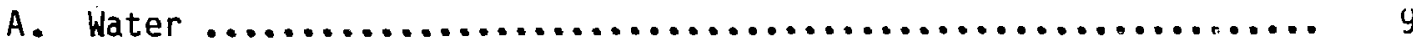

B. Volumetric Soil Moisture ............................. 10

C. Tracer ........................................ 1 i

v. CALCULATIUNS $\ldots \ldots \ldots \ldots \ldots \ldots \ldots \ldots \ldots \ldots \ldots \ldots \ldots \ldots \ldots \ldots \ldots \ldots \ldots \ldots \ldots \ldots$

A. Soil Water ............................................. 11

B. Tracer .......................................... 13

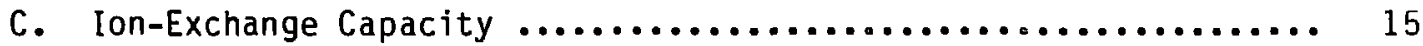

VI. RESULTS AND CONCLUSIONS $\ldots \ldots \ldots \ldots \ldots \ldots \ldots \ldots \ldots \ldots \ldots \ldots \ldots \ldots \ldots \ldots \ldots \ldots$

A. Moisture Regimes .................................. 15

B. Tracer Movement ................................. 17

VII. IMPLICATIONS OF THE RESULTS OF THE EXPERIMENT FOR SLB SYSTEMS ..... 19

A. Use of Biobarriers ............................... 19

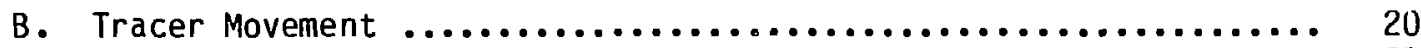

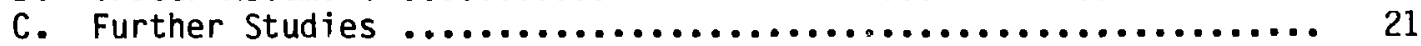

ACKNOWLEDGMENTS $\ldots \ldots \ldots \ldots \ldots \ldots \ldots \ldots \ldots \ldots \ldots \ldots \ldots \ldots \ldots \ldots \ldots \ldots \ldots \ldots \ldots \ldots \ldots \ldots$

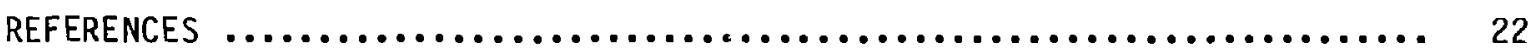

APPENDIX A. Water Additions to the Caissons ...................... 35

APPENDIX B. Discharge (Outflow) Data ......................... 47

APPENDIX C. Summary of Soil Moisture Data ...................... 51

APPENDIX D. Volumetric Moisture Data ........................... 59

APPENDIX E. Background Data ............................. 89

APPENDIX F. Tracer Concentrations in Outflow ..................... 93 


\title{
SUBSURFACE MOISTURE REGIMES AND TRACER MOVEMENT UNDER TWO TYPES OF TRENCH-CAP DESIGNS FOR SHALLOW LAND BURIAL SITES
}

\author{
by
}

B. A. Perkins and E. J. Cokal

\section{ABSTRACT}

The Los Alamos work has focused on proper design of shallow land burial (SLB) sites in arid and semiarid reyions and on applying corrective measures to existing sites.

One of the most important desiyn features affecting the probability of movement of radionuclides in SLB sites is the type of trench cap placed over the waste. The cap influences such interdependent parameters as erosion, water infiltration and percolation, and biointrusion. To obtain experimental data for arid and semiarid sites, two different designs of trench caps, one with topsoil underlain with a cobble/gravel biobarrier and one with topsoil underlain with crushed tuff, were compared with respect to (1) seasonal changes in volumetric soil water content and (2) downward migration of tracers emplaced directly below each type of trench cap. Due to the holdup of moisture (because of the differences in matric potential at the topsoil/biobarrier interface) until "breakthrough" occurred, the use of the biobarrier design resulted in "pulses of water" entering the underlying tracer layer. Because "breakthrough" would be expected to occur more easily in some regions than others (due to nonuniformities at the interface), water probably did not move uniformly into the region below the biobarrier. In contrast, the use of crushed tuff allowed water to percolate down through the topsoil profile. The buildup of moisture in the topsoil and rapid, large increase in moisture at the tracer layer was not observed. Moreover, soil water 
probably moved more uniformly through a given horizon.

After one growing season, with the addition of approximately $81 \mathrm{~cm}$ of precipitation, downward tracer movement had occurred. The movement of cobalt and strontium was greater in the biobarrier design than in the crushed-tuff design. Under both trench-cap designs, strontium was more mobile than cobalt, which was more mobile than cesium for the high concentrations added to the tracer layer. In a yiven horizon into which tracer had moved, nonuniform concentrations of tracer were found in both treatments. There was a much yreater nonunifcrmity across each horizon, particularly for strontium, in the biobarrier containing trench cap. Tracer inhomogeneity was probably related to the observed nonuniform distributions of soil moisture and perhaps channeling along instrumentation tubes.

After two growing seasons and the addition of a total of $178 \mathrm{~cm}$ of precipitation, significant strontium was found in the outflow water from the experimental columns utilizing the biobarrier treatment, whereas little strontium was found in the outflow water from the columns having the tuff cover.

This large-scale-type experiment indicates that under some conditions some contaminants may have a greater subsurface miyration using a biobarrier as compared to a crushed-tuff-only trench-cap design. The nonuniform concentrations of tracer found at a given horizon perhaps indicate preferred pathways for movement, particularly for the biobarrier design. Nonuniform covers or inhomogeneities in the soil may greatly influence preferred pathway movement. At SLB sites, under the conditions of unsaturated flow that generally occur at near-surface depths in arid and semiarid sites, nonuniform soil structures may make botn modeling and monitoring difficult, and mobilization of a contaminant may be greater than expected. Tre causes for the large differences in concentrations found in this experiment need to be investigated further. Problems in environmental modeling and monitoring of arid and semiarid SLB sites because of heterogeneities in the soil profiles and their implications for SLB waste management need to be better understood. More work in trench-cap design and its influence on the many pathways available for mobilization is needed. 


\section{INTRODUCTION}

Shallow land burial is one method used for the disposal of low-level radioactive wastes. Radionuclides contained in the waste can be mobilized and transported through several different pathways. Conditions that minimize movement by one pathway may result in greater moveinent through another pathway. Thus, the result of utilizing one management practice to reduce migration by a given pathway must be related to its effect on migration by other pathways. Good waste manayement requires implementing SLB site construction, which minimizes the likalihood for mobilization when all pathways are considered.

One potential pathway for mobilization and movement is for plant roots to penetrate into regions containing waste or leachate and for plant uptake and translocation of radionuclides to occur. Another potential pathway involves animal activities, including burrowing, which intersect the waste and cause dispersion and/or allow water to infiltrate (which in turn may lead to mobilization and transport). Special designs for backfill and surface cover that will minimize biological intrusion are being developed and evaluated at Los Alamos (Hakonson 1986).

One such desiyn consists of placing gravel and then cobble below the topsoil to act as a barrier through which plant roots will not readily penetrate and animals will not burrow. In this report, this design will be referred to as a "biobarrier."

If a biobarrier is used to reduce biological-transport pathways, the biobarrier must not significantly increase mobilization and transport of radionuclides through other pathways. The primary objectives of the experiment described in this paper were to compare (1) soil moisture as a function of depth and (2) movement of tracers in soil water having different 
sorption characteristics at sites incorporating a biobarrier with sites using only crushed tuff as backfill and cover.

The experimental conditions were chosen to simulate, as closely as possible, the conditions under which a burial site might operate. These included:

(1) Soil water--near-surface soils--unsaturated. This situation is typical of near-surface regions in the arid and semiarid climate of the western United States.

(2) Backfill--crushed tuff. This is the backfill for the low-level waste-burial sites at Los Alamos and is a representative silty sand.

(3) Tracers--stable cations strontium, cobalt, and cesium. These were chosen because they are present in many low-level wastes and have different mobilization characteristics (Perkins and DePoorter 1986). To achieve good sensitivity in detection since nonradioactive isotopes were used, it was necessary to add tracers in quantities much greater than those found in most low-level wastes. The stable anion chlorine was used as a conservative tracer.

(4) Vegetation--first-growing-season barley. This plant represents a quick-germinating annual with a rather shallow root system. Second-growing-season alfalfa. This plant represents a large water user with a deep root system (Foxx et al., "Rooting Depths of Plants Relative to Biological and Environmental Factors," 1984 and Foxx et al., "Rooting Depths of Plants on Low-Level Waste Disposal Sites," $1.984)$.

(5) Input-water events--maximum stress. To stress the biobarrier to determine conditions necessary for "breakthrough" to occur, the following input-water events were chosen: first summer, two major 
storm-event simulations--the first, 2 in of rain and the second, 4 in of rain; following winter, slow infiltration of natural snowmelt; second summer, steady influx of water resulting in a buildup of deeper soil moisture and outflow from the bottom of the experimental columns in both treatments.

(6) Time. Data were taken over the course of two growing seasons to determine the effects of season and extended operation.

\section{I1. EMPLACEMENT}

To simulate a waste-burial site as closely in scale as possible, the experiment was conducted in two 305-cm-diameter, 610-cm-long caissons (Fig. 1) that are part of an experimental cluster (DePoorter et al. 1982). Before each caisson (noted as $C$ and $D$ in Fig. 1) was filled, the bottom drains, which extended outward to allow for measurement of drainage, were covered with a coarse screen. Approximately $25 \mathrm{~cm}$ of gravel was placed over the screen, followed by approximately $25 \mathrm{~cm}$ of sand. Next, layers of compacted, screened, crushed tuff (optimum volumetric moisture approximately $13 \%$ for maximum compaction) were placed in each caisson until the total thickness of the tuff was $326 \mathrm{~cm}$.

'At this horizon in each caisson, two 5.08-cm-0D ihin-walled aluminum tubes $262 \mathrm{~cm}$ in length were positioned upright, one at the center and one $30 \mathrm{in}$ $(76.2 \mathrm{~cm})$ from the caisson wall (Fiy. 2). After filling each caisson with an additional $61 \mathrm{~cm}$ of compacted crushed tuff, a 2- to 5-cm tracer layer, containing $415.7 \mathrm{~g}$ of $\mathrm{CoCl}_{2}, 800 \mathrm{~g}$ of $\mathrm{CsCl}_{2}$, and $32.2 \mathrm{~kg}$ of $\mathrm{Sr}\left(\mathrm{NO}_{3}\right)_{2} \cdot 4\left(\mathrm{H}_{2} \mathrm{O}\right)$ mixed uniformly with 0.1 cubic meter of crushed tuff was added.

In the $C$ caisson, $100 \mathrm{~cm}$ of compacted crushed tuff was applied over the tracer. Finally, $60 \mathrm{~cm}$ of screened topsoil was spread over the tuff. In the 
D caisson, a biobarrier consisting of $75 \mathrm{~cm}$ of cobble followed by $25 \mathrm{~cm}$ of 3/4-in $(1.9 \mathrm{~cm})$ gravel was placed over the tracer followed by $60 \mathrm{~cm}$ of topsoil (Fig. 3)

On May 28, 1982, barley (Hordeum vulgare L..) seeds were spread over the surface of both caissons. The seeds were sprinkled with a 46\%-phosphoricacid-0\%-nitrogen-0\%-potash fertilizer and covered with a thin layer of peat moss. By June 1, 1982, the barley had beyun to sprout and continued to yrow until June 8, 1983, when the barley was removed. Then altalfa (Medicago sativa L..) seeds were spread on the caisson surfaces and were covered with a thin layer of sand and a light application of fertilizer. Alfalfa continued to grow until the experiment was terminated.

In August 1982 (at levels $197 \mathrm{~cm}, 271 \mathrm{~cm}, 347 \mathrm{~cm}$, and $422 \mathrm{~cm}$ below the surface), horizontal 5.08-cm-diameter holes were driven to the center of both the $r$, and $D$ caissons and cased with thin-walled 5.08-cm-OD aluminum tubing (Fic. 3). These holes were used for insertion of the neutron-moisture-gauge probe.

\section{TECHNIQUES}

This section will describe how the experimental data were obtained. Some discussion of factors influencing the data will be included.

\section{A. Precipitation}

A rotary-tyue flow meter was used to determine the amount of supplemental water sprinkled over the surface of each caisson. Natural precipitation data were obtained from a MRI rain yauge located at the experimental site. B. Soil Moisture

In the upper region of the caissons, volumetric soil moisture as a function of depth and distance from the caisson wall was obtained by inserting 
a neutron-moisture-yauge probe into each vertical aluminum access tube (Fiy. 2) and obtaining data at each of several selected depths.

For the lower regions of the caissons, data on moisture versus depth were obtained by inserting the probe into the horizontal aluminum tubes at the various levels (Fig. 3). To determine the horizontal moisture profiles, measurements were made outward in increments until the side of the caisson was reached.

A neutron moisture gauge is an "integrating" instrument and thus does not measure moisture at a point location. Experiments indicate that the maximum "integrated region" is approximately $30 \mathrm{~cm}$, with $20 \mathrm{~cm}$ being an average for soil moisture of 20-30\% (Nyhan et al. "Spatial Resolution," 1984). Thus, at interfaces such as cobble/gravel, tuff/gravel, and soil/air, or in other regions in which differences in soil moisture are quite large in a small region, the neutron moisture gauge will be unable to accurately define each specific region.

One of the neutron moisture gauges used in this experiment had been calibrated by collecting the tuff removed when one of the horizontal access holes was installed, obtaining the volumetric moisture, and comparing the results with the moisture measured by the probe once the aluminum casing was inserted. Use of the calibration data supplied by the gauge manufacturer gave the same volumetric moisture as found in the tuff sample (12\%). Because of (1) calibration limitations, (2) very small amounts of neutron absorber in the tuff, (3) counting statistics, (4) errors in positioning the probe instrument, and (5) instrument drift, integrated volumetric moisture measurements have an error of $+10 \%$. 


\section{c. Cores}

To determine how the tracer had moved during the first field season, jusi before the beginning of the second field season, core samples were taken in caissons $C$ and D at horizons $197 \mathrm{~cm}, 271 \mathrm{~cm}, 347 \mathrm{~cm}$, and $422 \mathrm{~cm}$ below the soil surface. At each position, a 2.22-cm-diameter thin-walled steel rod was driven horizontally to a distance of $30 \mathrm{~cm}$. The rod was retrieved and the sample was emptied into a labeled plastic bag. The rod was reinserted and driven horizontally for $20 \mathrm{~cm}$, again retrieved, and the sample emptied into another labeled plastic bag. Then 5 more $20-\mathrm{cm}$ interval samples were obtained. At this point, the rod had been driven to the center of the caisson. Thus, seven samples at different distances from the center of the caisson taken at each of the four horizons were obtained for each caisson, a total of 56 soil samples.

Each core sample was oven dried at $105^{\circ} \mathrm{C}$ for $24 \mathrm{~h}$ and was yround and mixed uniformly in a rod mill. Approximately $25 \mathrm{~g}$ of each sample was submitted for cesium, cobalt, and strontium analysis by neutron activation. (For more information on this type of analysis, the reader is referred to Gladney 1980 and Gladney 1982).

Core samp? ing has the disadvantage that unless a core is backfilled after it has been removed, cores can never again be taken from the same region. In saturated flow, flow might be distorted by coring. In the present experiment, soil-moisture data indicate that below the iracer, flow was unsaturated and coring should not have affected the future movement and distribution of tracer. Analysis of a dried cure saniple measures tracer in the soil water plus tracer sorbed on the soil, and hence does not indicate the distribution of tracer between soil water and soil matrix. 


\section{Outflow}

Once outflow from a caisson began, the rate was initially measured at least daily and later, as the flow decreased, at less frequent intervals. Water was collected in a araduated cylinder placed under the outflow pipe for 5 min. After noting the amount of water, samples were sent for analyses. Cesium was measured by flame atomic absorption using an $\mathrm{H}_{2}$-Ar flame. Cobalt was determined by $f l$ ame atomic absorption using an air- $i_{2} i_{2}$ flame. Strontium was determined by ICP spectrometry using $5.00 \mathrm{ppm}$ standard GDPSD with dilution as necessary. Chlorine was measured using an ion-selective electrode.

Because the outflow was a mixture of all the water draining from the caisson, specific information on composition of soil water as a function of position in a given horizon was not obtained. The outflow only contained tracer that had traveled through the entire column and did not give information on how far other tracers that were not detected in the outflow may. have traveled downward in each column.

IV. DATA

This section presents the data obtained from the experiment. A. Water

1. Additions of Water to the Caisson Surface. During the first field season (June 1982-June 1983), $16.55 \mathrm{in} .(42.0 \mathrm{~cm})$ of naţural precipitation and $15.50 \mathrm{in.}(39.4 \mathrm{~cm})$ of supplemental well water, including simulated storm events of 2. in of rain and of $4 \mathrm{in}$. of rain, were added to each of the caissons.

During the secorid field season (June 1983-February 1984), 6.13 in. (15.6 $\mathrm{cm}$ ) of natural precipitation and for caisson ( $31.82 \mathrm{in} .(80.8 \mathrm{~cm})$ and for caisson D $33.45 \mathrm{in} .(85.0 \mathrm{~cm})$ of supplemental weli water was added. 
Comprehensive data for water additions as a function of day are given in Tables A-I and A-II of Appendix A.

2. Outflow from the Bottom Pipe of the Caisson. On September 13, 1983, caisson D began to drain from the bottom outflow pipe and on September 27 , 1983, caisson C began to drain. Through January 1984, after which time the outflow was reduced to approximately ? liter a day, a total of $20 \mathrm{~cm}$ of water had flowed from caisson $D$ and $13.5 \mathrm{~cm}$ from caisson C. Detailed flow data are given in Appendix B, Table, B-I.

B. Volumetric Soil Moisture

1. First Field Season (May 1982-June 1983). Frequent measurements of volumetric soil moisture as a function of depth and position in the horizon were made during the 1982 field season. Because of the large amount of data, a summary of the vertical hole data, including the simulated 2 -in and 4 -in rainfalls and the winter snowmelt, is given in Tables C-I and C-II of Appendix C. A more complete data set is given in Appendix D.

Figure 4 indicates the differences in volumetric moisture of the two treatments for the 4-in. rainfall simulation. Figure 5 indicates the volumetric moisture distributions as a function of depth during winter snowmelt (February 9, 1983-February 22, 1983), whereas Figs. 6-9 indicate relative horizontal distributions under the tracer. The relative horizontal distributions are included because they represent soil moisture conditions before the core samples were collected.

2. Second Field Season (June 1983-February 1984). Tables C-III and C-IV of Appendix $C$ summarize vertical moisture measurements and Tables $C-V$ and $C-V I$ summarize horizontal moisture measurements made during the 1983 field season. A more complete data set is given in Appendix D. Figure 10 indicates changes 
in the vertical profiles of caisson C versus caisson [ between June 8, 1983 and September 14, 1983.

C. Tracer

1. Background. Background levels of cesium, strontium, cobalt, and chlorine in crushed-tutf soil water were obtained by analyzing outflow from caissons containing tuff but no tracers (Table E-I, Appendix E): Background levels of the ions listed above in the supplemental well water added to the caissons were also measured (Table E-II, Appendix E). To obtain backyround concentrations of cobalt, cesium, and strontium in the tuff, core samples were collected and analyzed (Table E-III, Appendix E).

2. Cores. The data obtained from the horizontal core samples taken on May 8, 1983, indicating concentrations of cation tracers as a function of location in a horizon and depth below the surface, are given in Table I.

3. Outflow. The results of analyzing the outflow for strontium, cobalt, cesium, and chlorine are given in Tables F-I through F-V of Appendix F with the exception of cesium and cobalt in caisson $C$, and cesium in caisson $D$ (because nondetectable levels of these were found in the respective outflow samples). The distribution of strontium as a function of time in the outflow of caisson D is graphed in Fig. 11 .

\section{CALCULATIONS}

\section{A. Soil Water}

Using the volumetric soil moisture data of Appendix $C$, soil moisture chariges above the tracer layer for various time periods in each caisson can be calculated (Table II).

Downward movement of water to the lower regions of the caissons resulted in buildup of soil moisture at the tuff/sand and sand/gravel interfaces at the 
CONCENTRATIONS OF TRACER FOUND IN CORES AS A FUNCTION OF DISTANCE FROM THE EDGE AND DEPTH

(ppm)

Sample Interval

from Edge

(cm)

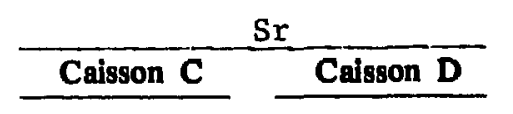

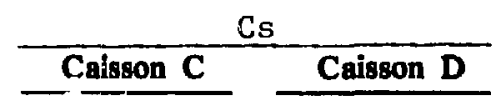

$197 \mathrm{~cm}$ below surface (37 cm below tracer 1ayer)

$\begin{array}{cccccc}0-30 & 119.0 \pm 13.8 & 82.9 \pm 10.2 & 16.50 \pm 1.67 & 3.76 \pm 0.38 & 129.00 \pm 13.00 \\ 30-50 & 73.9 \pm 10.3 & 56.0 \pm 8.2 & 15.60 \pm 1.57 & 9.53 \pm 0.96 & 108.00 \pm 10.90 \\ 50-70 & 137.0 \pm 15.7 & 69.2 \pm 9.1 & 13.40 \pm 1.35 & 12.40 \pm 1.25 & 145.10 \pm 14.60 \\ 70-90 & 71.6 \pm 8.7 & 87.2 \pm 10.7 & 13.20 \pm 1.34 & 15.80 \pm 1.60 & 151.00 \pm 15.20 \\ 90-110 & 43.7 \pm 6.8 & 90.5 \pm 10.5 & 15.30 \pm 1.55 & 16.90 \pm 1.70 & 159.00 \pm 16.00 \\ 110-130 & 52.5 \pm 7.7 & 120.0 \pm 13.2 & 14.90 \pm 1.51 & 15.40 \pm 1.56 & 195.00 \pm 19.60\end{array}$

$27.00 \pm 2.72$

$67.20 \pm 6.75$

$86.70 \pm 8.71$

$102.00 \pm 10.20$

$106.00 \pm 10.70$

$122.00 \pm 12.30$

$45.5 \pm 6.8 \quad 124.0 \pm 13.715 .40 \pm 1.56$

NA

$187.00 \pm 18.80$

NA

center $130-150$

$271 \mathrm{~cm}$ below surface ( $111 \mathrm{~cm}$ below tracer layer)

\begin{tabular}{|c|c|c|c|c|c|}
\hline $0-30$ & $929.0 \pm 93.9$ & $70.4 \pm 8.5$ & $1.81 \pm 0.18$ & $2.23 \pm 0.22$ & $2.43 \pm 0.25$ \\
\hline $30-50$ & $186.0 \pm 19.7$ & $147.0 \pm 16.2$ & $1.54 \pm 0.16$ & $3.57 \pm 0.36$ & $2.97 \pm 0.31$ \\
\hline $50-70$ & $160.0 \pm 17.8$ & $139.9 \pm 15.5$ & $2.09 \pm 0.21$ & $2.18 \pm 0.22$ & $2.54 \pm 0.26$ \\
\hline $70-90$ & $159.0 \pm 17.1$ & $171.0 \pm 18.3$ & $2.01 \pm 0.20$ & $3.65 \pm 0.37$ & $2.04 \pm 0.21$ \\
\hline $90-110$ & $214.0 \pm 22.7$ & $244.0 \pm 25.3$ & $1.45 \pm 0.15$ & $5.49 \pm 0.55$ & $2.48 \pm 0.25$ \\
\hline $110-130$ & $404.0 \pm 41.2$ & $700.0 \pm 70.8$ & $1.90 \pm 0.20$ & $12.10 \pm 1.22$ & $2.21 \pm 0.23$ \\
\hline enter $130-150$ & $1810.0 \pm 182.0$ & $3510.0 \pm 353.0$ & $4.38 \pm 0.44$ & $28.10 \pm 2.83$ & $2.46 \pm 0.25$ \\
\hline
\end{tabular}

$2.83 \pm 0.28$

$2.40 \pm 0.24$

$2.62 \pm 0.26$

$2.82 \pm 0.29$

$2.48 \pm 0.25$

$3.15 \pm 0.32$

$3.09 \pm 0.32$

$347 \mathrm{~cm}$ below surface (187 cm below tracer layer)

$\begin{array}{cclllll}0-30 & 14.8 \pm 3.9 & 19.8 \pm 4.6 & 2.43 \pm 0.26 & 3.35 \pm 0.34 & 2.36 \pm i .25 & 2.62 \pm 0.27 \\ 30-50 & 23.1 \pm 5.7 & 26.6 \pm 5.0 & 1.96 \pm 0.20 & 1.88 \pm 0.19 & 2.59 \pm 0.28 & 2.07 \pm 0.21 \\ 50-70 & 28.0 \pm 6.1 & 24.0 \pm 5.2 & 2.28 \pm 0.24 & 3.03 \pm 0.30 & 2.50 \pm 0.26 & 2.16 \pm 0.22 \\ 70-90 & 19.7 \pm 4.5 & 34.5 \pm 6.8 & 1.42 \pm 0.15 & 2.32 \pm 0.23 & 2.88 \pm 0.30 & 2.72 \pm 0.27 \\ 90-110 & 14.7 \pm 4.4 & 92.7 \pm 10.7 & 2.01 \pm 0.21 & 3.74 \pm 0.38 & 2.54 \pm 0.27 & 2.53 \pm 0.26 \\ 110-130 & 26.2 \pm 5.6 & 36.5 \pm 7.1 & 1.58 \pm 0.16 & 1.76 \pm 0.18 & 3.59 \pm 0.37 & 1.60 \pm 0.16 \\ \text { center } 130-150 & 20.7 \pm 5.4 & 38.6 \pm 6.5 & 1.70 \pm 0.17 & 3.32 \pm 0.33 & 2.79 \pm 0.28 & 2.36 \pm 0.24\end{array}$

$422 \mathrm{~cm}$ below surface $(262 \mathrm{~cm}$ below tracer)

$\begin{array}{ccccccc}0-30 & 23.3 \pm 4.9 & 27.6 \pm 6.0 & 1.37 \pm 0.14 & 2.26 \pm 0.23 & 3.65 \pm 0.38 & 2.49 \pm 0.26 \\ 36-50 & 21.8 \pm 5.2 & 15.7 \pm 5.0 & 1.34 \pm 0.14 & 3.60 \pm 0.37 & 2.69 \pm 0.29 & 2.75 \pm 0.29 \\ 50-70 & 16.3 \pm 3.7 & 28.1 \pm 7.2 & 1.41 \pm 0.15 & 1.63 \pm 0.17 & 2.52 \pm 0.26 & 2.81 \pm 0.29 \\ 70-90 & 27.6 \pm 6.3 & 24.1 \pm 5.5 & 1.42 \pm 0.15 & 0.86 \pm 0.12 & 2.56 \pm 0.28 & 2.76 \pm 0.29 \\ 90-110 & 21.4 \pm 4.2 & 23.0 \pm 5.2 & 0.58 \pm 0.08 & 2.03 \pm 0.20 & 2.16 \pm 0.22 & 2.45 \pm 0.25 \\ 110-130 & 20.7 \pm 6.1 & 32.6 \pm 7.1 & 0.90 \pm 0.13 & 2.85 \pm 0.29 & 2.32 \pm 0.24 & 2.45 \pm 0.25 \\ \text { center } 130-150 & 44.2 \pm 6.5 & 18.4 \pm 3.7 & 0.20 \pm 0.07 & 2.43 \pm 0.25 & 2.49 \pm 0.26 & 2.47 \pm 0.25\end{array}$

a Background not subtracted. 
bottom of the caissons until "breakthrough" occurred and drainaye began (Perkins at a1. 1985). Because changes in moisture at these interfaces cannot be experimentally determined, flux through the tracer and changes in moisture storage below the tracer layer cannot be calculated.

\section{B. Tracer}

1. Relative Concentrations in Cores. The relative concentrations of a tracer in each complete horizontal core can be obtained by multiplying the measured average concentration in a segment by the length of the segment and adding the results for all segments in the same horizon (Table III).

\section{Tracer Loss in Outflow.}

a. Strontium. In analyzing the outflow, the only cation tracer found in detectable amounts throughout the period of drainage was strontium in caisson D. For this caisson, multiplying the measured outflow on a given day by the strontium concentration of the outflow of that day and adding indicates a total inventory loss of approximately $5091 \mathrm{~g}$. Since $9950 \mathrm{~g}$ of strontium were initially in the tracer layer and background data wouid indicate that little strontium could have been introduced from other sources, approximately $51 \%$ of the strontium tracer moved through the underiying material $(449 \mathrm{~cm})$ to the outflow in caisson 0 .

b. Chlorine. The same calculations can be made for anion chlorine to derive a total loss of chlorine in the outflow of approximately $526.5 \mathrm{~g}$ from caisson D and $494.4 \mathrm{~g}$ from Cáissor C. Initially, $167 \mathrm{~g}$ of chlorine was contained in the $\mathrm{CsCl}_{2}$ tracer and $224 \mathrm{~g}$ was in the $\mathrm{CoCl}_{2}$ tracer, for a total of $391 \mathrm{~g}$. In addition, approximately $22 \mathrm{~g}$ were added because of the presence of chlorine in supplemental water. Because approximately 1500 I of soil water moved through the tuff in caisson $C$ and $D$, natural tuff leaching should add 75 9 of chlorine to the total, giving a total original inventory of $488 g$ of 
TABLE II

MOISTURW CHANGE IN THE REGION ABOVE THE TRACER IN CAISSONS C AND D AS A'FUNCTION OF TIME

\begin{tabular}{|c|c|c|c|c|}
\hline \multirow[b]{2}{*}{ Time Period } & \multicolumn{4}{|c|}{$\begin{array}{c}\text { Change in Moisture Above } \\
\text { Tracer }\left(\mathrm{cm} \mathrm{H}_{2} \mathrm{O}\right)\end{array}$} \\
\hline & $\begin{array}{l}\text { Caisson C } \\
\text { Hole } 1 \\
\end{array}$ & $\begin{array}{c}\text { Caisson C } \\
\text { Hole2 } \\
\end{array}$ & $\begin{array}{c}\text { Caisson D } \\
\text { Hole1 }\end{array}$ & $\begin{array}{l}\text { Caisson D } \\
\text { Hole2 } \\
\end{array}$ \\
\hline $\begin{array}{l}\text { June } 11 \text { - Nov 3, } 1982 \\
\text { Nov 3,1982 - Mar 13, } 1983\end{array}$ & $\begin{array}{r}-4.9 \\
+10.2\end{array}$ & $\begin{array}{l}-5.4 \\
+9.6\end{array}$ & $\begin{array}{l}-2.6 \\
+7.9\end{array}$ & $\begin{array}{l}-5.1 \\
+9.3\end{array}$ \\
\hline $\begin{array}{l}\text { June } 28 \text { - Sept } 14,1983 \\
\text { Sept } 14,- \text { Dec } 15,1983 \\
\text { Dec 16, } 1982 \text { - Feb 15, } 1984\end{array}$ & $\begin{array}{r}+9.2 \\
-11.7 \\
+3.2\end{array}$ & $\begin{array}{r}+9.4 \\
-13.4 \\
+3.2\end{array}$ & $\begin{array}{l}+4.0^{2} \\
-14.1 \\
+11.8\end{array}$ & $\begin{array}{l}+0.1^{\mathrm{a}} \\
-9.7 \\
+8.0\end{array}$ \\
\hline $\begin{array}{l}\text { June i } 1,1982 \text { - Sept 14, } 1983 \\
\text { June } 11,1982 \text { - Feb } 15,1984\end{array}$ & $\begin{array}{r}+14.5 \\
+6.0\end{array}$ & $\begin{array}{r}+13.6 \\
+3.8\end{array}$ & $\begin{array}{l}+9.3 \\
+7.0\end{array}$ & $\begin{array}{l}+4.3 \\
+2.6\end{array}$ \\
\hline
\end{tabular}

TABLE III

RELATIVE CONCENTRATIONS OF TRACERS IN CORES (ppmcm)

\begin{tabular}{|c|c|c|c|c|c|c|}
\hline \multirow{3}{*}{$\begin{array}{l}\text { Depth }(\mathrm{cm}) \\
\text { below tracer }\end{array}$} & \multirow{2}{*}{\multicolumn{2}{|c|}{$\frac{\mathrm{Sr}}{\text { Caisson }}$}} & \multirow{2}{*}{\multicolumn{2}{|c|}{$\frac{\text { Co }}{\text { Caisson }}$}} & \multirow{2}{*}{\multicolumn{2}{|c|}{$\frac{\text { Cs }}{\text { Caisson }}$}} \\
\hline & & & & & & \\
\hline & C & D & C & D & C & $\mathbf{D}$ \\
\hline 37 & 12054 & 13425 & 2251 & $1822^{\mathrm{a}}$ & 21770 & $12488^{\circ}$ \\
\hline 111 & 86530 & 100332 & 322 & 1169 & 367 & 416 \\
\hline 187 & 3092 & 5652 & 292 & 421 & 409 & 347 \\
\hline 262 & 3739 & 3666 & 158 & 336 & 404 & 388 \\
\hline
\end{tabular}

ainterval from $130-150 \mathrm{~cm}$ estirnated 
chlorine in each caissor. This tota? is approximately the total chlorine found in each of the outflows from caisson $C$ and $D$.

C. Ion-Exchange Capacity

1. Crushed Tuff. The total ion-exchange capacity for crushed tuff sieved to $1 \mathrm{~mm}$ has been measured as 0.3 milli-equivaients per $100 \mathrm{~g}$ of soil. * Thus, in the region below the tracer layar, since there were approximately $39.8 \times 10^{6} \mathrm{~g}$ of tuff, the tuff would have a total capacity of $11.96 \times 10^{4}$ milli-equivalents [if it is assumed that ion-exchange capacity is not a function of particle (sieved) size for the porous tuff].

2. Strontium. If $9.95 \times 10^{3} \mathrm{~g}$ of strontium were in the tracer layer, and if this strontium became solubilized in the soil water, the strontium would have a total of $22.7 \times 10^{4} \mathrm{mi} 11$ i-equivalents.

VI. RESULTS AND CONCLUSIONS

A. Moisture Regimes

1. Vertical. The vertical-moisture profiles (Figs. 4, b, and 10) indicate very different soil moisture behavior in caisson C (crushed tuff) versus caisson D (biobarrier). In caisson D, soil water increased (because of differences in matric potential) at the soil/biobarrier interfaces until "breakthrough" occurred. After each of these events: the soil water moved rapidly through the gravel/cobble giving a "pulse" input to the surface of the tracer layer. In caisson C (tuff), each input-water event at the surface moved downward through the underlying tuff. Thus, in caisson $C$, soil water movement at the tracer zone did not occur as sudden "breakthrough surges" as in caisson D. (It should be noted that volumetric soil-moisture levels in the

*This information was provided by Edward Essington, Group HSE-12, Los Alamos National Laboratory, June 1984. 
region below the tracer were always measured to be less in caisson $C$ than in caisson D soon after "breakthrough" in caisson D.)

Under the initial moisture conditions present in the caisson, 2 in. of water did not cause "breakthrough" in caisson D, whereas 4 in. did. The data also indicate that winter snowmelt, under the climatic conditions of Los Alamos, can cause "breakthrough" with the design used in caisson D. During the second field season, "breakthrough" also occurred under conditions of the steady application of a total of approximately $100 \mathrm{~cm}$ of water.

Although $5 \mathrm{~cm}$ more water was added to the biobarrier caisson than the crushed tuff, approximately $7 \mathrm{~cm}$ more water drained out. Thus, the use of a biobarrier may have resulted in slightly greater percolation. (However, the differences between percolation in caisson D over caisson C is very small and may be due to errors in measurement of input moisture and moiscure originally in the caissons.)

2. Horizontal. If the data taken in tub!: $C_{1}$ are compared with the data from $C_{2}$, and $D_{1}$ with $D_{2}$, the moisture measured at a given level in the two vertical holes of the same caisson is not the same. The differences can also be noted in the differences in moisture changes calculated for the two holes of the same caisson (Table II). The nonuniform volumetric moistures continue downward to at least $422 \mathrm{~cm}$ as indicated by the data for the horizontal traverses. The moisture differences would appear to indicate nonuniform moisture infiltration and storage throughout the depth of each caisson. It would appear that at times, caisson $D$ had greater differences in volumetric soil moisture at a given horizon than did caisson $C$. These differences may o:cur because of greater channeling of moisture through the biobarrier in caisson D. 


\section{B. Tracer Movement}

1. Horizontal (Cores). For the very large amount of tracer used in the experiment (levels much greater than would be expected in leachate from radioactive waste), the data from core samples (Table I) indicate that, at least to some extent, all the cation tracers exhibited nonuniform migration. The degree of nonuniformity of tracer from one location to another in a horizon varied from a very slight amount for cesium in caisson $C$ to a factor of 50 in the concentration of strontium in the center and outer core at the 271-cm depth in caisson $D$.

While more data would be helpful, it appears that tracer nonuniformity was greater under the biobarrier than under the crushed tuff. The nonuniform concentration of tracer may relate to the nonuniform volumetric moistures measured horizontally in the caisson since the differences in hydraulic conductivity would result in nonuiliform soil water movement downward.

2. Vertical (Cores). Tables I and III can be used to compare the extent of downward movement of the cation tracers below the tracer layer at the time of coring (May 1983) for the two experiments. In caisson C, strontium had moved at least $111 \mathrm{~cm}$ below the original tracer layer, whereas in caisson $D$ it had moved at least. $187 \mathrm{~cm}$. In caisson C, extensive movement of cobalt was noted to at least $37 \mathrm{~cm}$ below the original tracer location and a small component to $187 \mathrm{~cm}$, whereas in caisson D extensive movement to at least 111 $\mathrm{cm}$ occurred with again a small component to at least $262 \mathrm{~cm}$ below the original tracer layer. In both caissons $C$ and $D$, cesium had moved to at least $37 \mathrm{~cm}$ below the tracer layer.

Thus, for the same moisture inputs during the first fieid season, the biobarrier design showed greater movement of cobalt and strontium and yreater heterogenzity in a given horizon than the tuff design. This result may be due 
to greater nonuniformity in caisson $D$ because of the use of a biobarrier and/ar because of the "pulse" type of moisture inflow to the tracer layer. (It should be noted that subsidence was obsarved in the upper soil layer of caisson D several weeks after emplacement of the experiment.)

In tuff, strontium appears to be the most mobile of the emplaced cation tracers. This agrees with the work of Essington, * Perkins, and Christenson (Perkins and Depoorter 1986 and Chrisienson et al. 1968). The core data also suggest that cobalt is retained less well than cesium. This also agrees with the data obtained by Essington ${ }^{*}$ for high concentrations (approximately $500 \mathrm{ppm}$ ) of both tracers. There appears to be a small mobile component of cobait, perhaps related to colloid movement, that moved in both surface cap treatments. A mobile component of cobalt was also detected in earlier work by Perkins (Perkins et al. 1985).

3. Outflow. Above background concentrations of cesium were not detected in the outflow from either caisson. These results are similar to those obtained with the cores that indicated that cesium was the least mobile cation tracer.

In caisson $C$, cobalt levels remained (within the analytical errors) at background. In the caisson D outflow, smäll amounts of cobalt were detected during late November through December.

High concentrations of strontium were detected in the caisson D outflow, with only small isolated above-background "blips" detected in outflow from caisson $C$. Considering that the cores taken at the beginning of the second field season showed strontium in caisson $D$ to have undergone the greatest and most nonuniform movement, and the fact that $4.2 \mathrm{~cm}$ more water was applied to

\footnotetext{
*This information was provided by Edward Essington, Group HSE-12, Los Alamos National Laboratory, June 1984.
} 
caisson D than C during the second field seasor, the appearance of strontium in the caisson D outflow water might be expected. Comparing (see Section $C-V$ ) the calculated total exchange capacity of the tuff below the tracs: with the calculated exchange capacity of all the strontium that was added in the tracer, if strontium occupied all the exchige sites, approximately $52 \%$ of the strontium originally in the trocer would be retained in the tufi below the tracer. However, cobalt and cesium will also occupy sites. as well as natur? $]_{j}$ occurring elements found in the tuff. Hence, more than $48 \%$ of the strontium would be expected to be found in the outflow water if all the strontium was solubilized and enough water was added to move the strontium through. Thus, it is not surprising that for caisson D, $51 \%$ of the strontium originally present in the tracer was removed by caisson-water outflow.

Since chlorine moves with the soil water, the appearance of chlorine in the outflow water of both caissons $C$ and $D$ indicates, as expected, that water moved through the tracer layer and down through the caissons to the bottom drainage.

VII. IMPLICATIONS OF THE RESULTS OF THE EXPERIMENT FOR SLB SYSTEMS A. Use of Biobarriers

Because of the difference in matric potential between the overlying soil and the cobble/gravel layer, percolating liquid will not penetrate ("breakthrough") the biobarriei until the overlying finer soil material nears saturation (Abeele and DePoorter 1984). This breakthrough event results in a pulse of water entering the region just below the biobarrier. It may also be that the breakthrough occurs irregularly across the horizon due to inhomogeneities in the soil/cobble/gravel interfaces and that preferred pathways of water percolation are established. If vegetation, climatic regimes, and 
surface designs are such that breakthrough can occur fairly frequently through the biobarrier, tracer (contaminant) mobilizaton and downward movement may be greater than if no biodarrier was installed.

Before a biobarrier is used at a burial site, the many variables in relationship to the site need to be considered. It may be necessary to use additional soil cover for increased storage capacity. Capillary barriers that move the percolating iiquid away from the burial region can reduce subsurface percolation (Abeele and DePoorter 1984). Other types of migration barriers may also be considered (Lane and Nyhan 1984). The construction of disposal pits with liners that resist deterioration for many years can be used to minimize subsurface-contaminant migration (Lane and Nyhan 1984).

Arid sites having little prospect for sudden increases in soil moisture and, hence, "breakthrough" may not require additional controls.

What is important to consider in disposal pit and cap design is that the performance of the disposal technique is very much a function of interactive processes. Performance is site specific, depends on all the different co.ponents designed into the system, and must be considered for maximum stress conditions and conditions that may occur over a long period (Hakonson 1986; Lane and Nyhan 1984; Nyhan, DePoorter, et al. 1984; Perkins et al. 1985; Perkiris and DePoorter 1986).

\section{B. Tracer Movement}

Perhaps one of the most important results of the experiment was the indication that tracer (contaminant) may follow "channels" through the subsoil. This makes modeling of tracer movement and monitoring to detect possible movement very difficult at these depths. It would appear that it may be possible for a core sample taken below one position in a waste disposal 
site to give very different results than a core sample taken even a few meters away.

The fact that the biobarrier design showed larger differences in tracer concentration across a given horizon than did the more homogeneous control would indicate that surface and near-surface heterogeneities may be important in downward movement of water along preferred pathways under unsaturated flow. The caisson experiments were carefully emplaced. Under field conditions, the heterogeneities and, hence, irregularities in moisture percolation and tracer movement might be larger than was found in the caissons. C. Further Studies

Further study is needed on the movement of tracer located below a gravel/cobble barrier if no "breakthrough" occurs. Wick systems that divert the percolating moisture and/or deeper soil covers need to be modeled and tested.

Studies on why the tracer was found to be so nonuniformly distributed across the caisson at a given norizon and at what depth more uniform distributions might occur should be undertaken as soon as possible. The role of heterogeneities in the structure of soils versus the movement under unsaturated conditions of percolating moisture needs to be better understood. The possibility for channeling down the vertical instrument access holes needs to be investigated. The fact that different results may have been obtained if the tracers had not been directly below the biobarrier (and, thus, wouid not be subject to very sudden inflows of soil moisture) needs to be assessed.

\section{ACKNOWLEDGMENTS}

The authors wish to thank G. DePoorter and T. Hakonson for design and supervision of installation of the experiment; the Experimental Science Group 
and the Zia Company for installation; E. Lopez, W. Herrera, and E. Karlen for aid in field work; E. Stallings, E. Gladney, and N. Raybold for aid in sample analysis; and T. Jacques, M. Lewis, C. Lujan, and M. Moore for typing.

\section{REFERENCES}

W. V. Abeele and G. L. DePoorter, "Testing of Lateral Water Flow in a Moisture Barrier," Los Alamos National Laboratory report LA-10125-MS, (June 1984).

C. W. Christenson, E. F. Fowler, G. L. Johnson. E. H. Rex, and F. A. Viyil, "Soil Absorption of Radioactive Wastes at Los Alamos," Sewage and Industrial Wastes 30(12), 1478-1489 (December 1968).

G. L. DePoorter, W. V. Abeele, and B. W. Burton, "Experiments to Determine the Migration Potential for Water and Contaminants in Shallow Land Burial

Facilities: Design, Emplacement, and Preliminary Results," in Waste Management ' 82 Vol. II (Proceedings of the Symposium on Waste Management, Tucson, Arizona, March 8-11, 1982), pp. 649-655.

T. S. Foxx, G. D. Tierney, and J. M. Williams, "Rooting Depths of Plants Relative to Biological and Environmental Factors," Los Alamos National Laboratory report LA-10254-MS (November 1984).

T. S. Foxx, G. D. Tierney, and J. M. Williams, "Rooting Depths of Plants on Low-Level Waste Disposal Sites," Los Alamos National Laboratory report LA-10253-MS (November 1984).

E. S. Gladney, D. B. Curtis, D. R. Perrin, J. W. Owens, and W. E. Goode, "Nuclear Techniques for the Chemical Analysis of Environmental Matarials," Los Alamos Scientific Laboratory report LA-8192-MS (January 1980).

E. S. Gladiey, D. R. Perrin, and W. E. Goode, "Quality Assurance for Environmental Analytical Chemistry 1982," Los Alamos National Laboratory report LA-9950-MS (1982).

T. E. Hakonson, "Evaluation of Geologic Materials to Limit Biological Intrusion into Low-Level Radioactive Waste Disposal Sites," Los Alamos National Laboratory report LA-10286-MS (1986).

L. Lane and J.W. Nyhan, "Water and Contaminant Movement: Migration Barriers," Los Alamos National Laboratory report LA-1024.2-MS (November 1984).

J. W. Nyhan, G. L. DePoorter, B. J. Drennon, J. R. Simanton, and G. R. Foster, "Erosion of Earth Covers Used in Shallow Land Burial at Los Alamos, New Mexico," Journal of Environmental Quality 13(3), 361-366 (July--September 1984).

J. W. Nyhan, B. J. Drennon, J. C. Rogers, and W. V. Abeele, "Spatial Resolution of Soil Water Content by Three Neutron Moisture Gauges," Los Alamos Nationa? Laboratory document LA-UR-83-2863 (1984). 
B. A. Perkins, B. J. Travis, and G. L. DePoorter, "Validation of the TRACR3D Code for Soil Water Flow Under Saturated/Unsaturated Conditions in Three Experiments," Los Alamos National Laboratory report LA-10263-MS (January 1985).

B. A. Perkins and G. L. DePoorter, "Plants and Their Relationship to Soil Moisture and Tracer Movement," Los Alamos National Laboratory report LA-10216-MS (1986). 

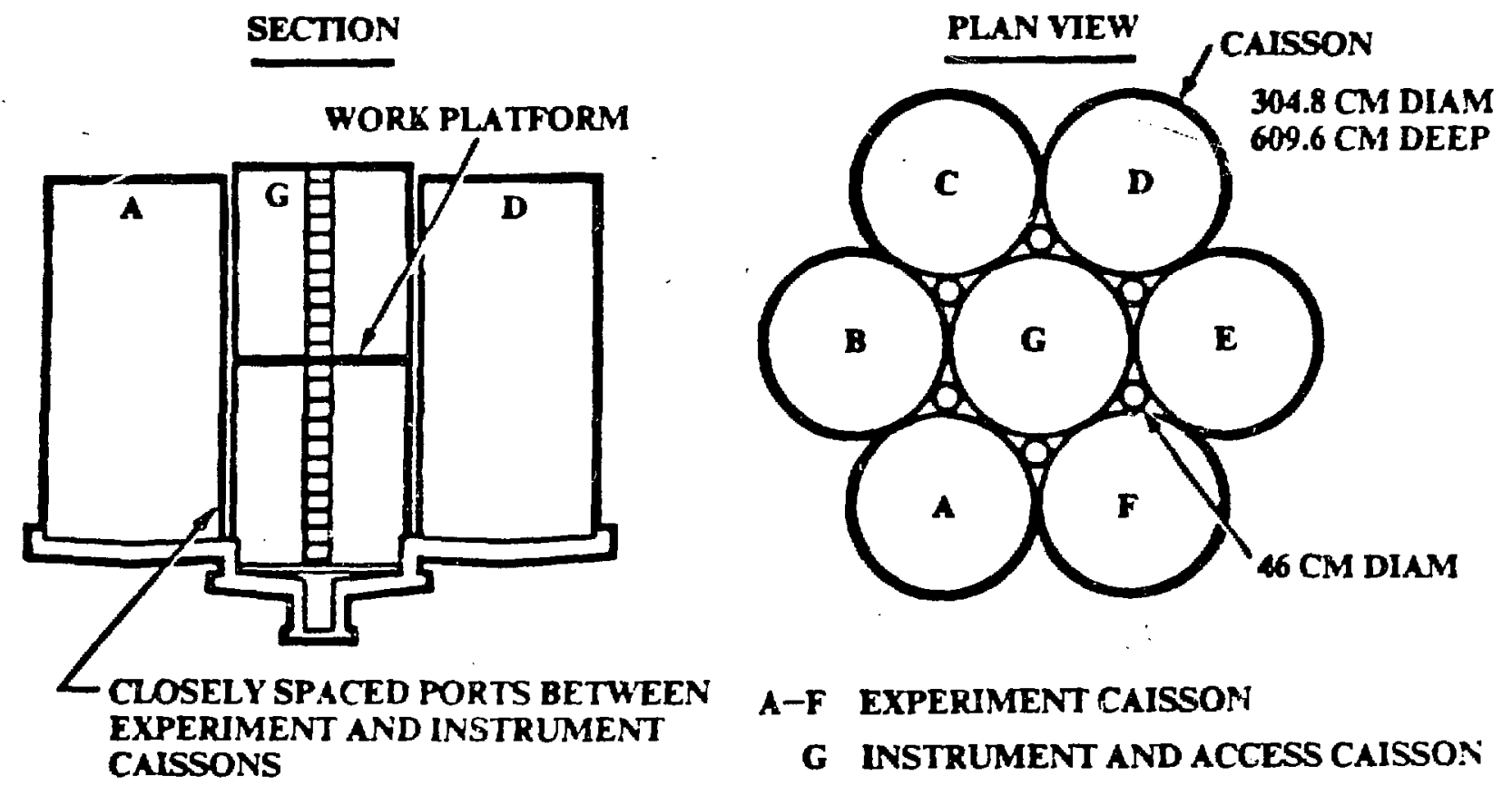

Fig. 1. Experimental cluster. 


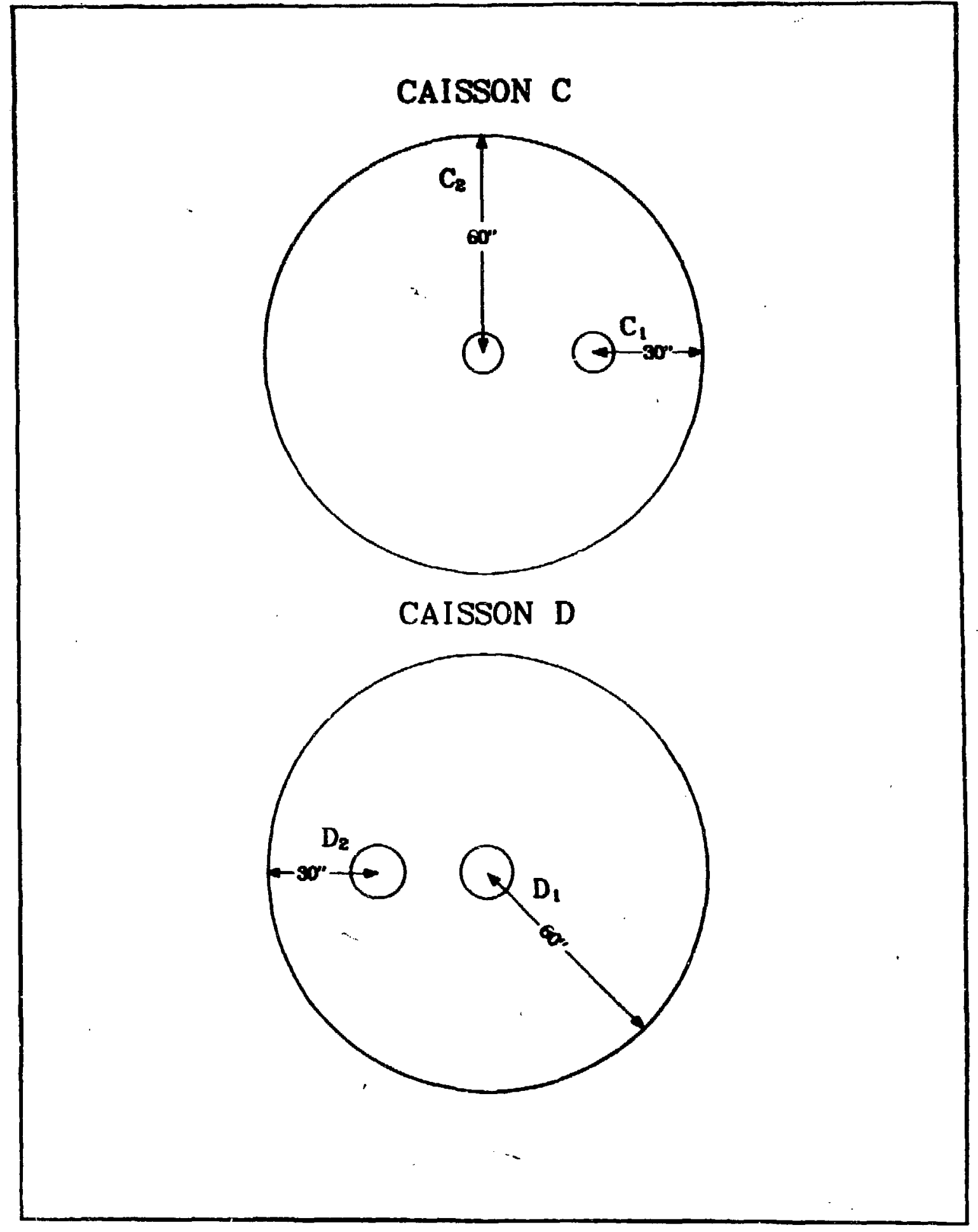

Fig. 2. Location and numbering of access tubes in caissons $C$ and $D$ looking down to the top surface. 


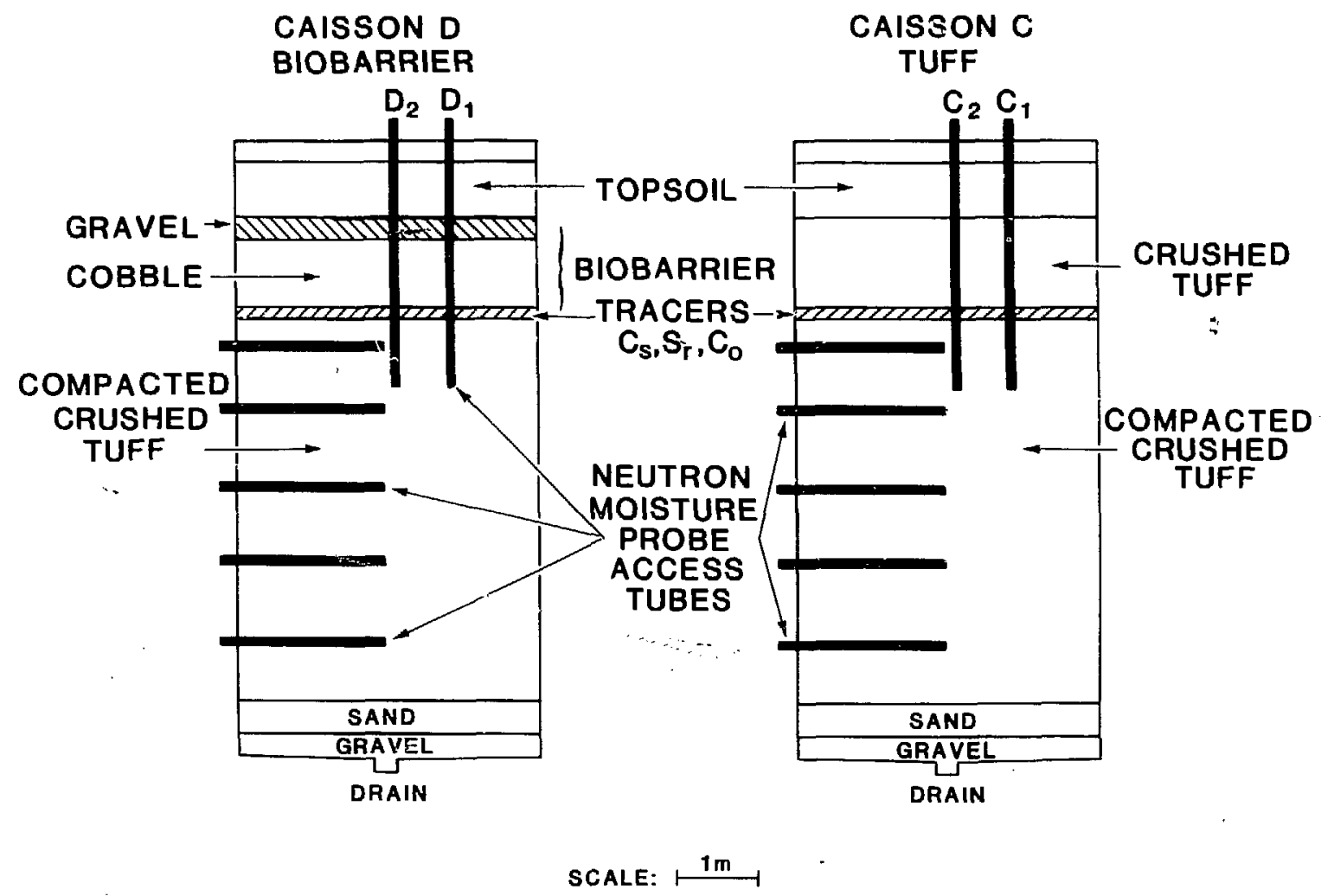

Fig. 3. Layout of two treatments. 


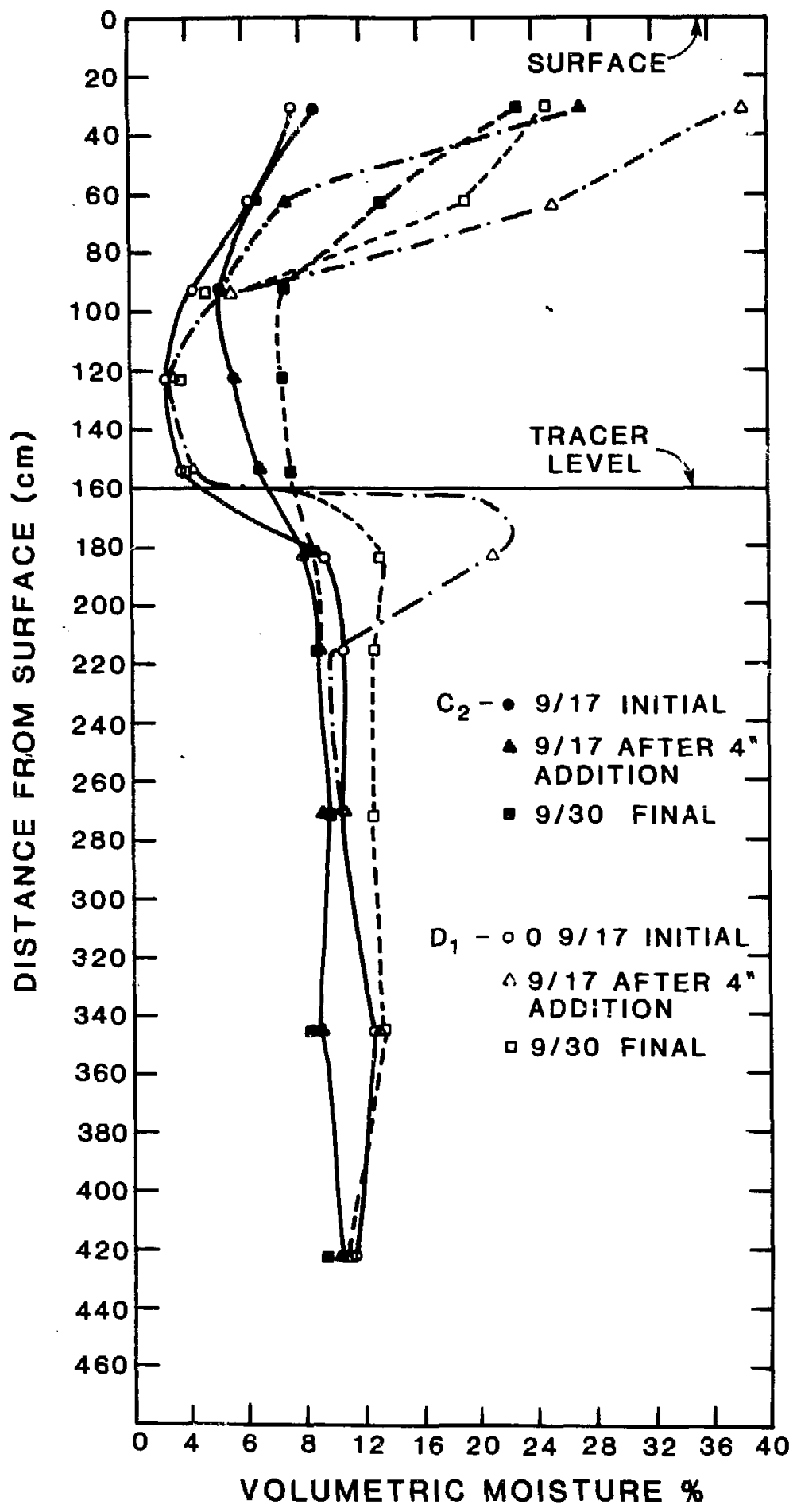

Fig. 4. Behavior of $C$ versus $D$ upon receiving 4 in. of water. 


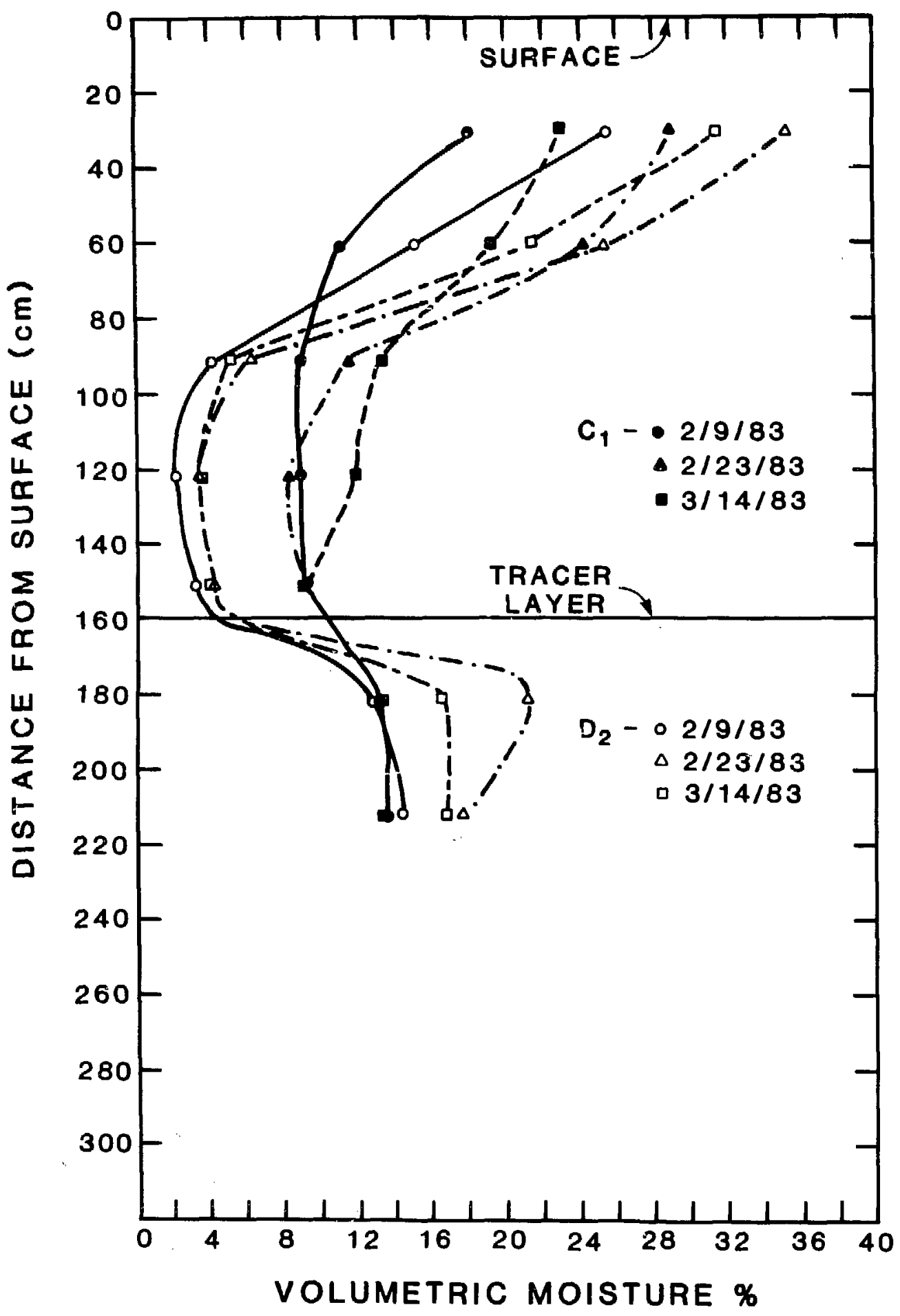

Fig. 5. Infiltration of winter snowmelt 1983. 


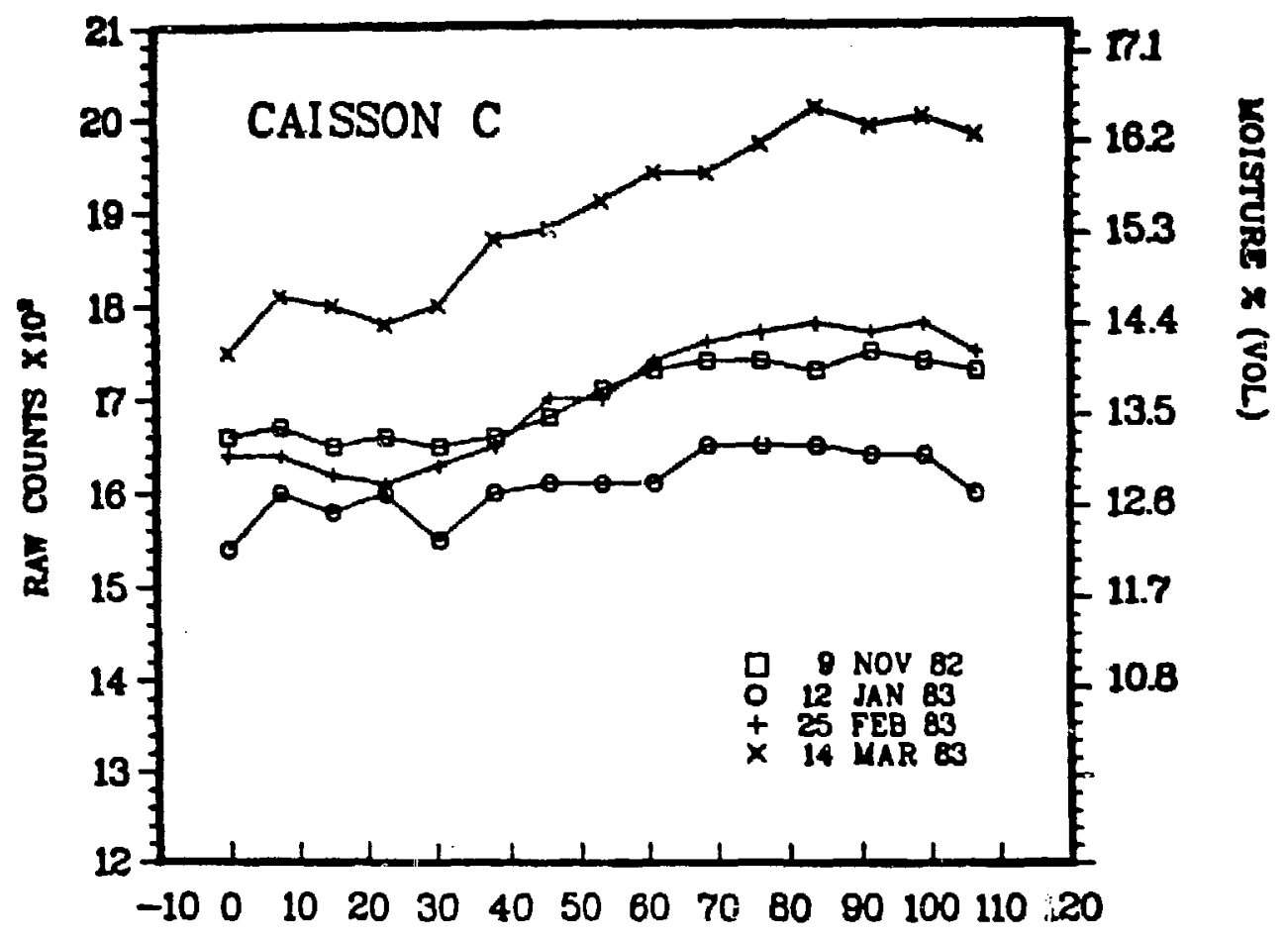

DISTANCE FROM CENTER IN CM

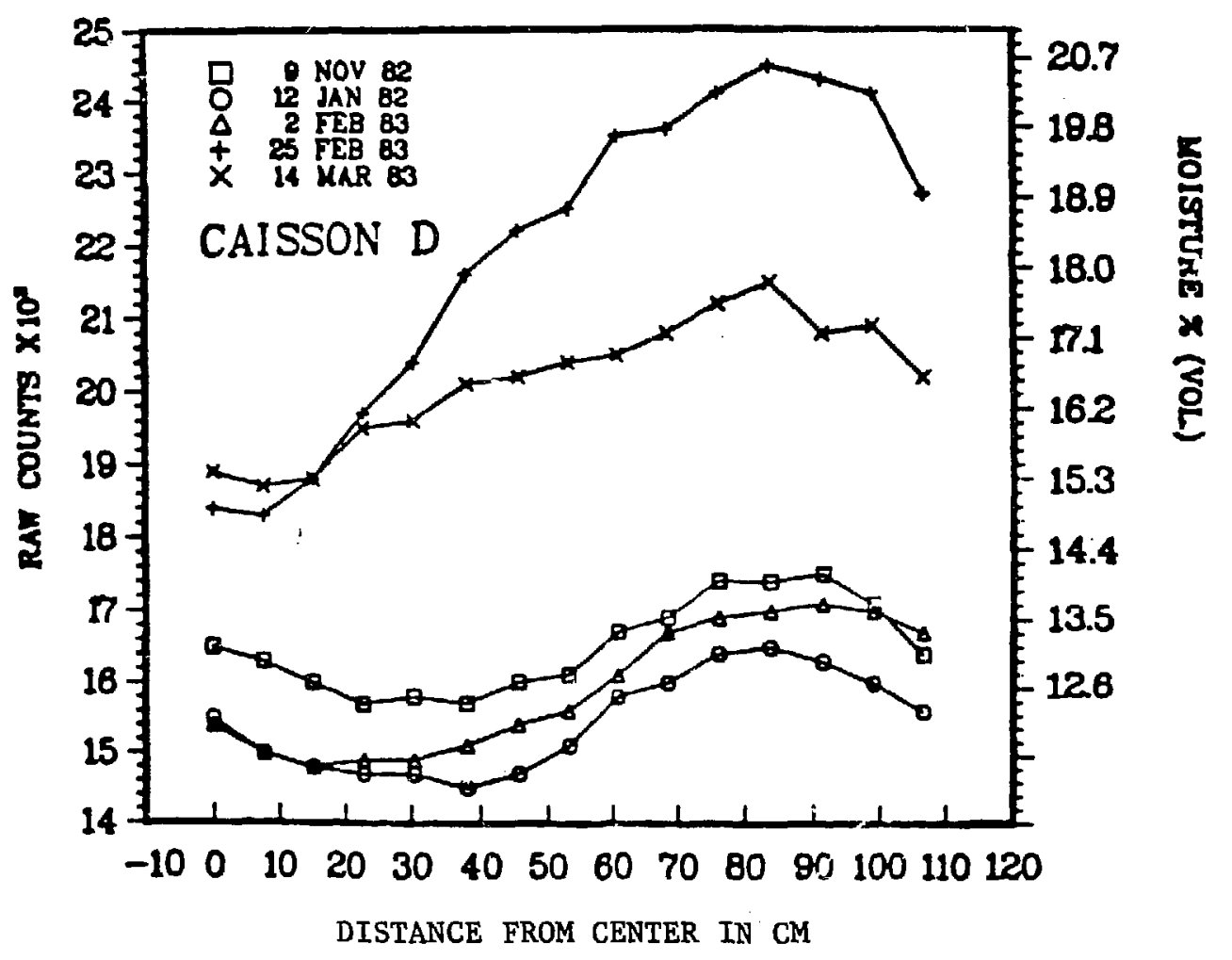

Fig. 6. Horizontal profile of caissons C and D at $197 \mathrm{~cm}$ depth. 


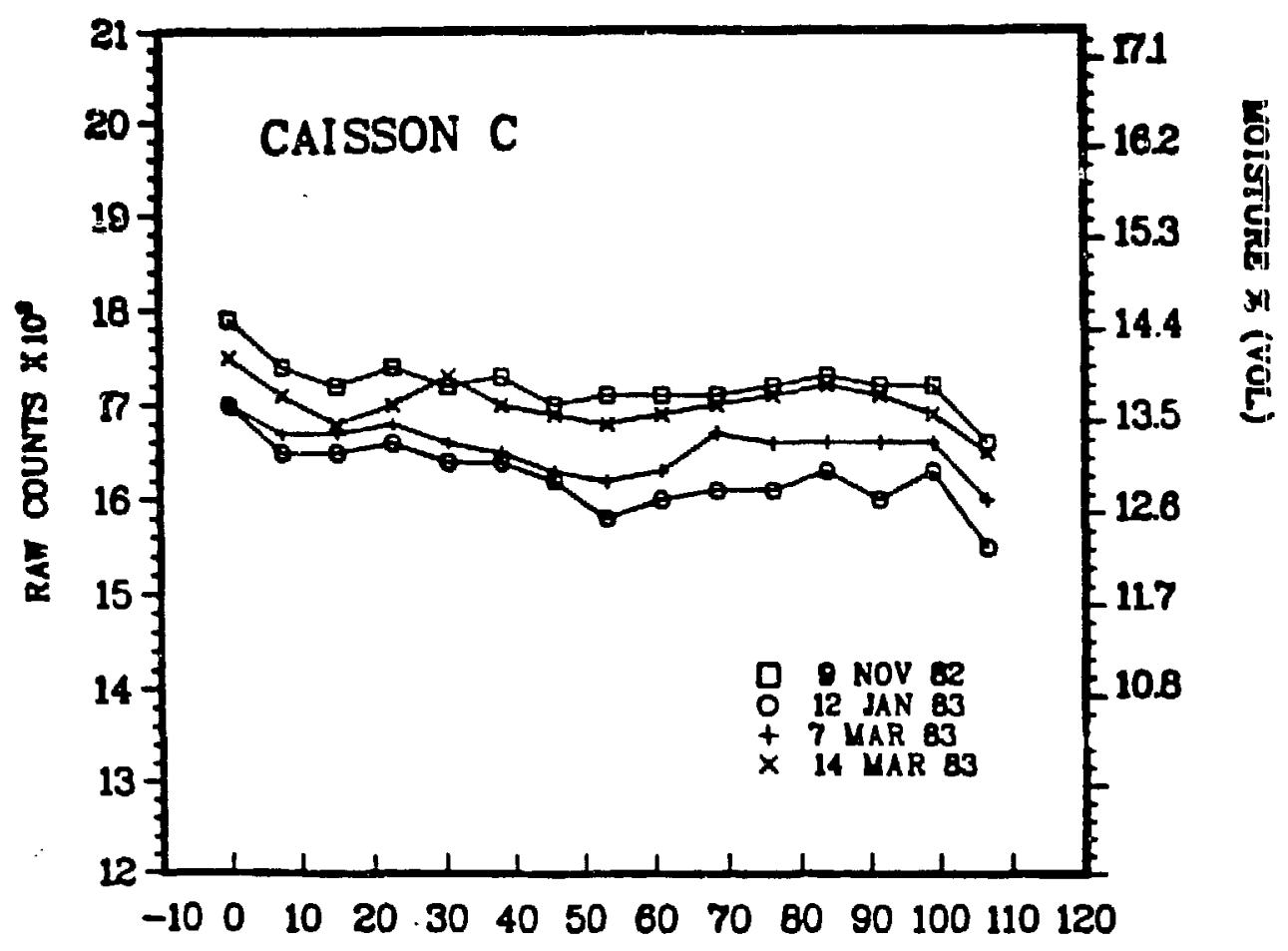

DISTANCE FROM CENTER IN CM

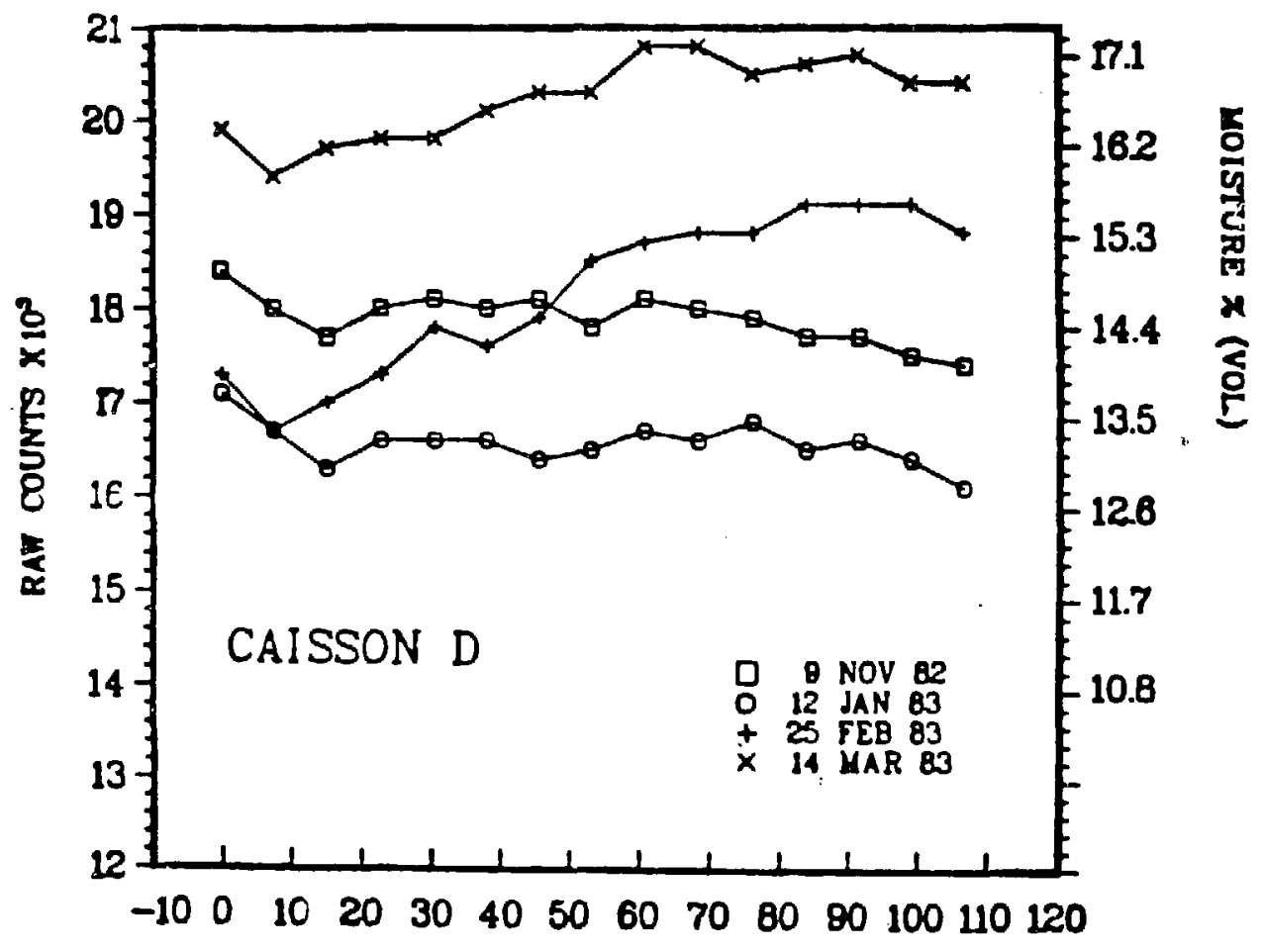

DISTANCE FROM CENTER IN CM

Fig. 7. Horizontal profile of caissons C and D at $271 \mathrm{~cm}$ depth. 

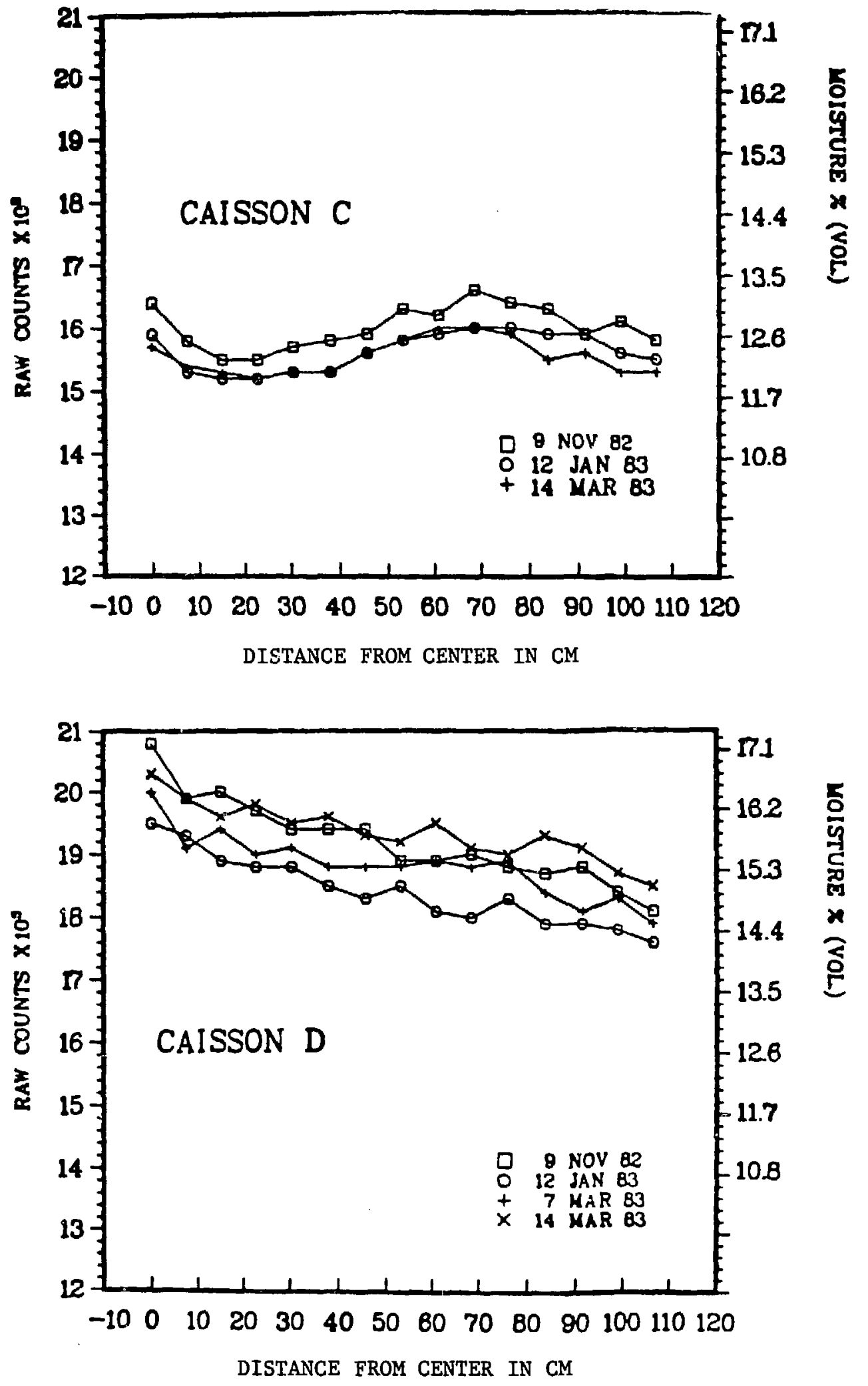

Fig. 8. Horizontal profile of caissons $C$ and $D$ at $347 \mathrm{~cm}$ depth. 


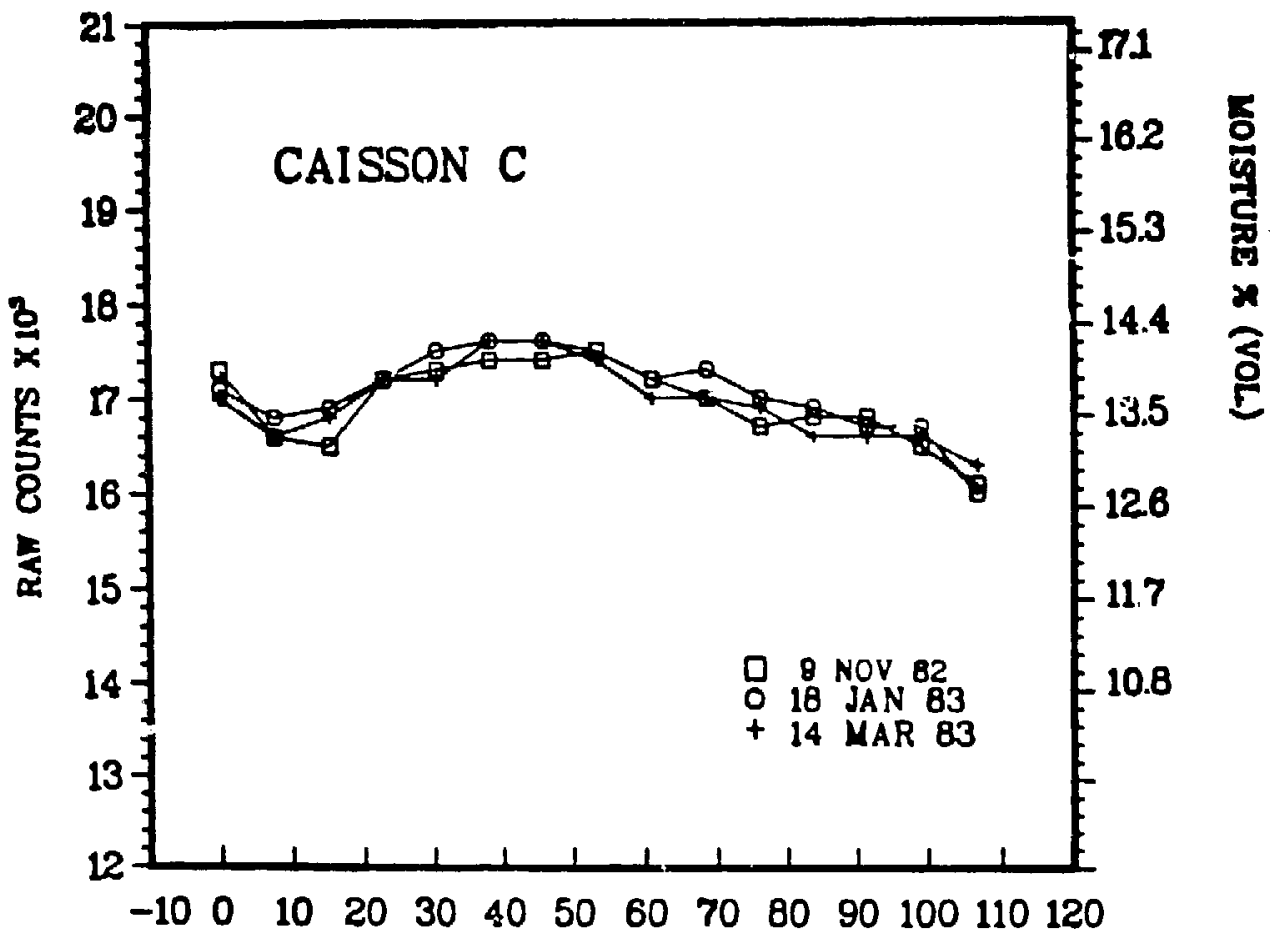

DISTANCE FROM CENTER IN CM

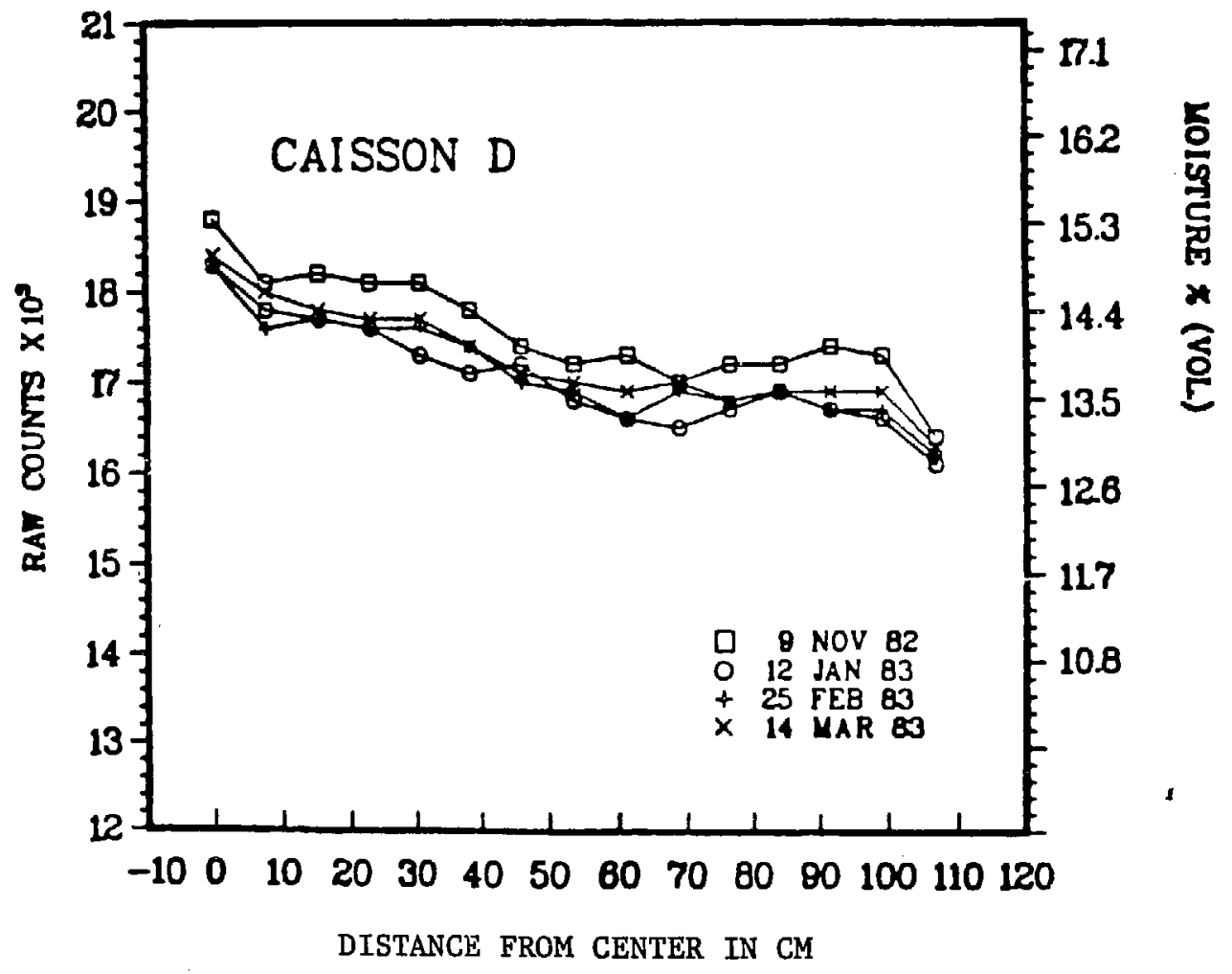

Fig. 9. Horizontal profile of caissons $C$ and $D$ at $422 \mathrm{~cm}$ depth. 


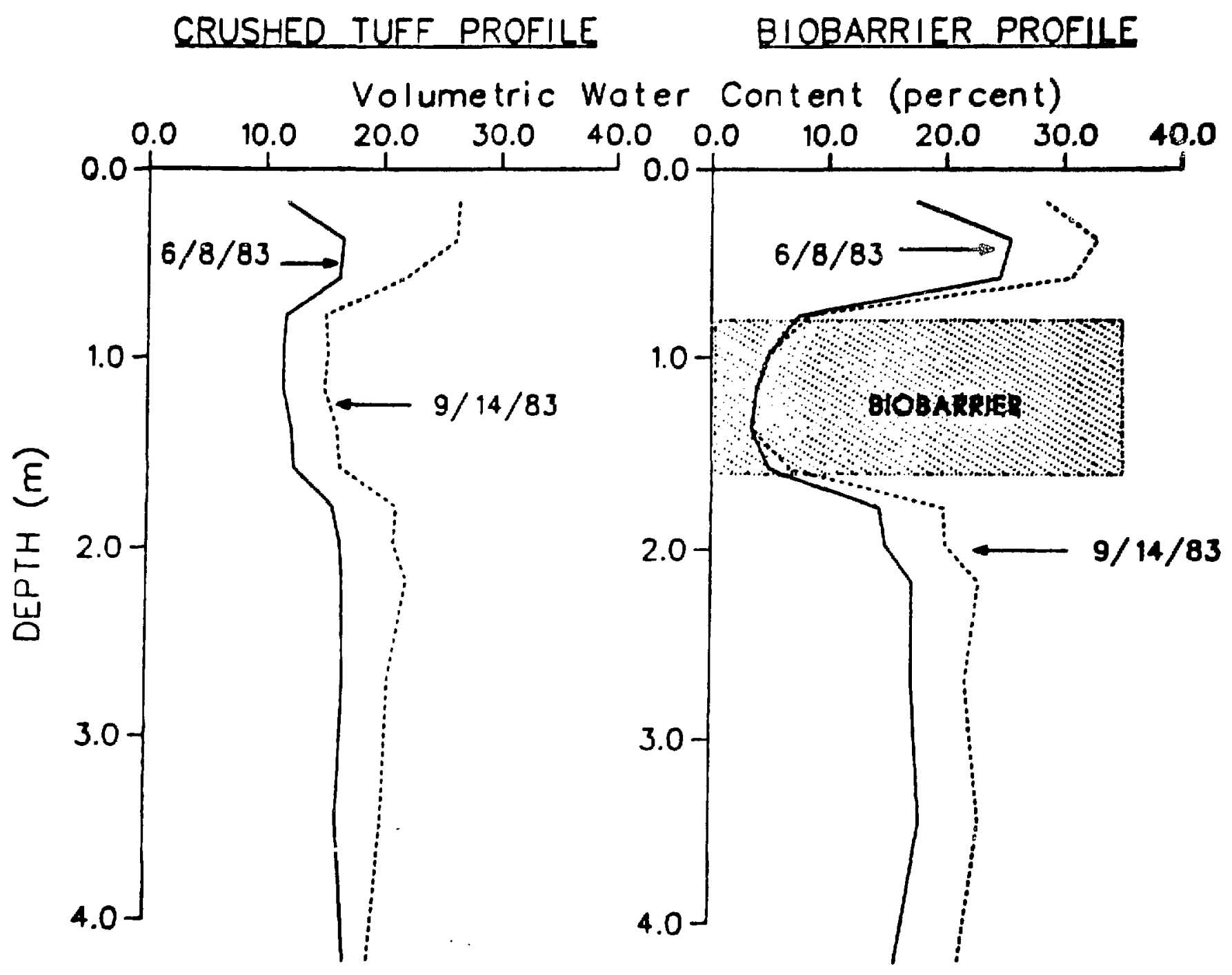

Fig. 10. Comparison of treatments under conditions of steady additions of water. 


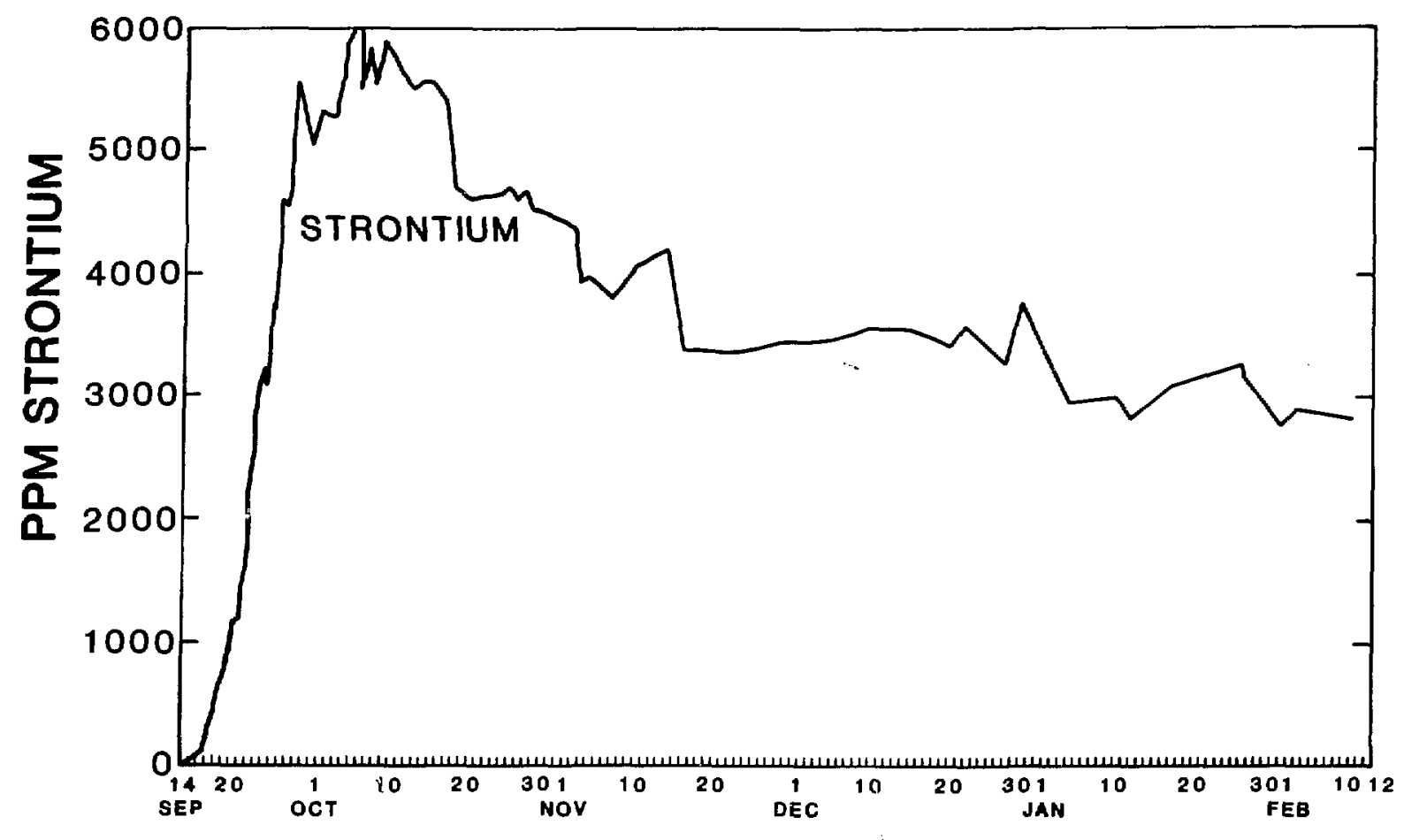

Fig. 11. Outflow from caisson D. 
APPENDIX A

Water Additions to the Caissons 
Table A-I: Natural and Supplemental Water in Inches for the First Field Season, June 1982--June 1983

\begin{tabular}{|c|c|c|}
\hline $\begin{array}{l}\text { June } \\
1982 \\
\end{array}$ & Natural & $\begin{array}{c}\text { Supplemental } \\
\text { (each caisson) }\end{array}$ \\
\hline $\begin{array}{r}3 \\
4 \\
7 \\
8 \\
9 \\
10\end{array}$ & .03 & $\begin{array}{l}3.1 \\
1.13 \\
1.13 \\
.75 \\
.75\end{array}$ \\
\hline $\begin{array}{l}11 \\
14 \\
15 \\
16 \\
18 \\
20\end{array}$ & .41 & $\begin{array}{r}.75 \\
.38 \\
.38 \\
.38 \\
.38 \\
\end{array}$ \\
\hline Totals & .44 & 9.50 \\
\hline $\begin{array}{l}\text { July } \\
1982 \\
\end{array}$ & Natural & $\begin{array}{c}\text { Suppl emental } \\
\text { (each caisson) }\end{array}$ \\
\hline $\begin{array}{l}11 \\
14 \\
16 \\
17 \\
18 \\
19\end{array}$ & $\begin{array}{l}.94 \\
.09 \\
.05 \\
.03 \\
.55 \\
.02\end{array}$ & \\
\hline $\begin{array}{l}27 \\
28 \\
29 \\
30 \\
31\end{array}$ & $\begin{array}{r}.12 \\
.06 \\
1.04 \\
.07 \\
.01 \\
\end{array}$ & \\
\hline Totals & 2.98 & 0 \\
\hline
\end{tabular}




$\begin{array}{rrr}3 & .03 & \\ 9 & .17 & \\ 11 & .04 & \\ 14 & .05 & \\ 16 & .27 & \\ 17 & .02 & \\ 18 & .02 & \\ 19 & .30 & \\ 21 & .49 & \\ 22 & .22 & \\ 23 & .08 & \\ 24 & .67 & \\ 25 & .14 & \\ 26 & .09 & \\ 29 & .05 & \\ 30 & .04 & \\ \text { Totals } & .04 & \end{array}$

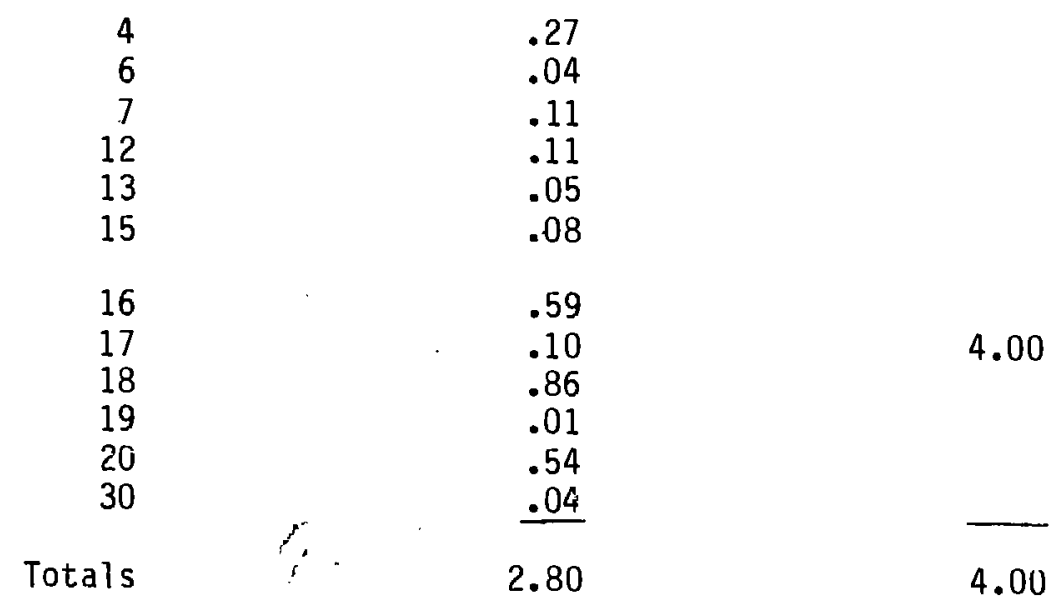




\begin{tabular}{|c|c|c|c|}
\hline $\begin{array}{c}\text { October } \\
1982 \\
\end{array}$ & Natural & $\begin{array}{l}\text { Supplemental } \\
\text { (each caisson) }\end{array}$ & \\
\hline $\begin{array}{r}2 \\
11 \\
12 \\
13 \\
27\end{array}$ & $\begin{array}{r}.01 \\
.19 \\
.23 \\
.01 \\
.09 \\
\end{array}$ & 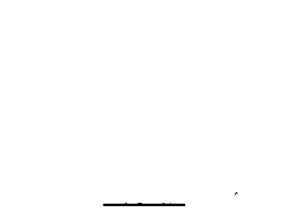 & \\
\hline Totals & .53 & 0 & \\
\hline $\begin{array}{c}\text { November } \\
1982 \\
\end{array}$ & Natural & $\begin{array}{c}\text { Supplemental } \\
\text { (each caisson) }\end{array}$ & \\
\hline $\begin{array}{r}3 \\
8 \\
9 \\
10 \\
17 \\
18\end{array}$ & $\begin{array}{l}.05 \\
.22 \\
.30 \\
.76 \\
.13 \\
.02\end{array}$ & & \\
\hline $\begin{array}{l}25 \\
27 \\
28 \\
29 \\
30\end{array}$ & $\begin{array}{r}.06 \\
.01 \\
.02 \\
.02 \\
.13 \\
\end{array}$ & & . \\
\hline Totais & 1.72 & 0 & \\
\hline
\end{tabular}


December

\begin{tabular}{rr}
3 & .02 \\
4 & .03 \\
8 & .22 \\
9 & .70 \\
10 & .14 \\
23 & .31 \\
24 & .03 \\
27 & .12 \\
28 & .11 \\
& .10 \\
\hline 5 & 1.68
\end{tabular}

January 1983

$\begin{array}{rr}17 & .02 \\ 21 & .04 \\ 29 & .05 \\ 30 & .14 \\ 31 & .75 \\ \text { Totals } & 1.00\end{array}$

.02

.22

.70

.14

.31

03

.12

.11

1.68
Supplementa 1

(each caisson)
Natural

Supplemental

(each caisson) 


$\begin{array}{rr}1 & .02 \\ 3 & .21 \\ 4 & .30 \\ 24 & .03 \\ 25 & .02 \\ \text { Totals } & .58\end{array}$

02

21

30

03

02

.58

0

March

\begin{tabular}{rr}
3 & .20 \\
4 & .08 \\
15 & .04 \\
17 & .01 \\
18 & .17 \\
19 & .09 \\
20 & .13 \\
21 & .07 \\
22 & .28 \\
24 & .12 \\
25 & .10 \\
\hline Totals & 1.29
\end{tabular}

20

.08

01

i17

09

13

.07

28

12

10

.29

0 
April

$\begin{array}{rr}5 & .05 \\ 6 & .01 \\ 7 & .03 \\ 12 & .05 \\ 14 & .03 \\ 21 & .03 \\ \text { Totals } & .20\end{array}$

14

15

20

25

26

29

30

Totals
Natural

Supplemental

(each caisson)

Suppl emental

Natural

(each caisson) 
Table A-II: Natural and Supplemental Water in Inches for the Second Field Season June 1983--February 1984

June 1983
Natural

.01

.02

.08

.01

9

11

13

15

17

19

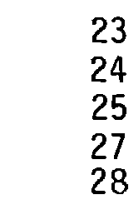

Totals

5

7

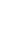

1

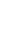

17

23

24

25

27
28

28

.01

.04

.20

.02

.39
Supplemental

Caisson C Caisson D
.60

.60

.30

.30

.30

.30

.30

.30

.40

.23

.30

.30

.30

.40

.30

.30

.30

.30

3.10

3.03
Supplemental Caisson C

Caisson D

.03

.09

.02

.02

\begin{tabular}{rrr} 
& .60 & .60 \\
& 1.40 & 2.80 \\
& .90 & .90 \\
.27 & .66 & .66 \\
.05 & .60 & .60 \\
.01 & .84 & .84 \\
-49 & 2.00 & 2.00 \\
\hline & 8.92 & 10.32
\end{tabular}


August

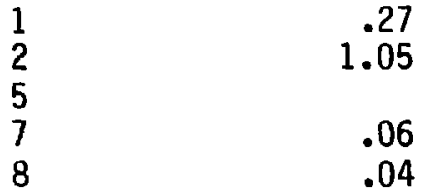

$11 \quad .22$

15

16

18

20

22

25

26

27

28

30

Totals

September

.02

.05

.05

.08

.20

2.04
Supplemental

Caisson C Caisson D

$\begin{array}{ll}1.1 & 1.1 \\ 1.0 & 1.0\end{array}$

2.0

2.0

.7

1.0

$2.0 \quad 2.0$

$2.0 \quad 2.0$

2.0

2.0

$\underline{2.0} \quad \underline{2.0}$

$12.8 \quad 13.1$

$\begin{array}{rr}1 & .05 \\ 6 & \\ 9 & \\ 10 & .03 \\ 11 & .26\end{array}$

13

24

26

27

28

29

30

Totals

.01

.18

.05

.03

.01

.07

.69
Supplemental

Caisson C Caisson D

$\begin{array}{ll}2.0 & 2.0 \\ 2.0 & 2.0 \\ 2.0 & 2.0\end{array}$

$1.0 \quad 1.0$ 
October

1983

1
2
6
8
20

Totals
Natural

\section{.41}

.12

.03

.38

.17
Suppl emental Caisson C

Caisson D

November 1983

$\begin{array}{rr}8 & .03 \\ 18 & .04 \\ 19 & .06 \\ 20 & .05 \\ 21 & .05 \\ 26 & .06 \\ 28 & .02 \\ 15 & .31\end{array}$

December 1983

Natural

Supplemental Caisson C Caisson D
Suppl ementa] Caisson C

Caisson D

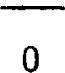

0

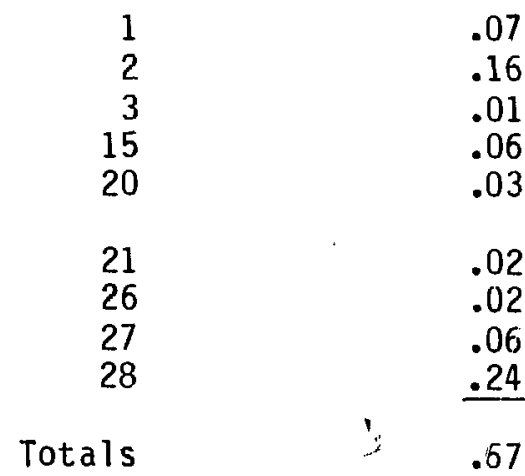


APPENDIX B

Discharge (Outflow) Data 
TABLE B-I

OUTFLOW AS A FUNCTION OF TIME IN CAISSONS C AND $\mathrm{D}^{\mathrm{a}}$ ( $(/$ day)

\begin{tabular}{|c|c|c|}
\hline \multicolumn{3}{|c|}{ September 1983} \\
\hline Day & $\begin{array}{c}\text { Caisson } \\
\text { D }\end{array}$ & $\begin{array}{c}\text { Caisson } \\
\text { C }\end{array}$ \\
\hline 15 & 60.5 & no drip \\
\hline 16 & 56.2 & no drip \\
\hline 17 & 50.4 & no drip \\
\hline 18 & 47.5 & no drip \\
\hline 19 & 46.1 & no drip \\
\hline 20 & 41.8 & no drip \\
\hline 21 & 41.8 & no drip \\
\hline 22 & 40.3 & no drip \\
\hline 23 & 38.9 & no drip \\
\hline 24 & 37.4 & no drip \\
\hline 25 & 34.6 & no drip \\
\hline 26 & 33.1 & no drip \\
\hline 27 & 31.7 & 7.2 \\
\hline 28 & 28.8 & 14.4 \\
\hline 29 & 28.8 & 20.2 \\
\hline 30 & 27.4 & 20.2 \\
\hline Total & 645.3 & 62.0 \\
\hline
\end{tabular}

\begin{tabular}{|c|c|c|}
\hline \multicolumn{3}{|c|}{ October 1983} \\
\hline Day & $\begin{array}{c}\text { Caisson } \\
\text { D }\end{array}$ & $\begin{array}{c}\text { Caisson } \\
\mathrm{C}\end{array}$ \\
\hline 1 & 27.4 & 15.8 \\
\hline 2 & 24.5 & 20.2 \\
\hline 3 & 23.0 & 21.6 \\
\hline 4 & 21.6 & 18.7 \\
\hline 5 & 20.2 & 18.7 \\
\hline 6 & 20.2 & 20.2 \\
\hline 7 & 20.2 & 20.2 \\
\hline 8 & 20.2 & 20.2 \\
\hline 9 & 17.3 & 17.3 \\
\hline 10 & 17.3 & 17.3 \\
\hline 11 & 15.8 & 17.3 \\
\hline 12 & $(15.0)$ & $(17.3)$ \\
\hline 13 & 14.4 & 17.3 \\
\hline 14 & 14.4 & 15.8 \\
\hline 15 & 14.4 & 14.4 \\
\hline 16 & 14.4 & 14.4 \\
\hline 17 & 13.0 & 14.4 \\
\hline 18 & 13.0 & 14.4 \\
\hline 19 & (13.0) & $(14.0)$ \\
\hline 20 & $13.0^{\prime}$ & 13.0 \\
\hline 21 & (13.0) & $(13.0)$ \\
\hline 22 & $(12.0)$ & (13.0) \\
\hline 23 & $(11.0)$ & $(13.0)$ \\
\hline 24 & 10.0 & 13.0 \\
\hline 25 & 8.6 & 11.5 \\
\hline 26 & 8.6 & 11.5 \\
\hline 27 & 8.6 & 11.5 \\
\hline 28 & 8.6 & 11.5 \\
\hline 29 & (8.6) & $(11.5)$ \\
\hline 30 & (8.6) & (11.5) \\
\hline 31 & 8.6 & 11.5 \\
\hline
\end{tabular}

Total 458.5 475.0 :

\begin{tabular}{|c|c|c|}
\hline \multicolumn{3}{|c|}{ November 1983} \\
\hline Day & $\begin{array}{c}\text { Caisson } \\
\text { D }\end{array}$ & $\begin{array}{c}\text { Caisson } \\
C\end{array}$ \\
\hline 1 & 8.6 & 10.9 \\
\hline 2 & 8.6 & 10.0 \\
\hline 3 & 8.6 & 9.8 \\
\hline 4 & 7.9 & 9.6 \\
\hline 5 & $(7.5)$ & (9.5) \\
\hline 6 & (7.5) & (9.5) \\
\hline 7 & 7.2 & 9.5 \\
\hline 8 & 7.2 & 8.6 \\
\hline 9 & 7.2 & 8.6 \\
\hline 10 & 6.5 & 8.6 \\
\hline 11 & $(6.5)$ & (8.6) \\
\hline 12 & $(6.5)$ & (8.6) \\
\hline 13 & (6.5) & $(8.6)$ \\
\hline 14 & 6.5 & 8.6 \\
\hline 15 & $(6.5)$ & (8.6) \\
\hline 16 & 6.5 & 8.6 \\
\hline 17 & $(6.5)$ & $(8.0)$ \\
\hline 18 & 6.5 & 7.2 \\
\hline 19 & $(6.5)$ & $(7.0)$ \\
\hline 20 & $(6.0)$ & (7.0) \\
\hline 21 & $(6.0)$ & (6.5) \\
\hline 22 & $(5.5)$ & (6.5) \\
\hline 23 & 5.2 & 6.2 \\
\hline 24 & $(5.0)$ & $(6.0)$ \\
\hline 25 & $(5.0)$ & (6.0) \\
\hline 26 & $(5.0)$ & (6.0) \\
\hline 27 & $(5.0)$ & $(6.0)$ \\
\hline 28 & 4.3 & 5.8 \\
\hline 29 & $(4.3)$ & $(6.0)$ \\
\hline 30 & (4.3) & (6.0) \\
\hline Total & 190.9 & 236.4 \\
\hline
\end{tabular}


TABLE B-I (cont)

December 1983

\begin{tabular}{|c|c|c|}
\hline Day & $\begin{array}{c}\text { Caisson } \\
\text { D } \\
\end{array}$ & $\begin{array}{c}\text { Caisson } \\
\mathrm{C} \\
\end{array}$ \\
\hline 1 & (4.5) & $(6.0)$ \\
\hline 2 & 4.7 & 6.2 \\
\hline 3 & $(4.5)$ & (5.5) \\
\hline 4 & (4.5) & (5:5) \\
\hline 5 & 4.3 & 5.2 \\
\hline 6 & $(4.2)$ & $(5.0)$ \\
\hline 7 & 4.2 & 4.6 \\
\hline 8 & $(4.0)$ & (4.6) \\
\hline 9 & 3.7 & 4.7 \\
\hline 10 & (3.7) & (4.7) \\
\hline 11 & (3.7) & (4.7) \\
\hline 12 & (3.7) & (4.7) \\
\hline 13 & 3.7 & 4.7 \\
\hline 14 & (3.7) & (4.5) \\
\hline 15 & 3.7 & 4.3 \\
\hline 16 & (3.7) & (4.3) \\
\hline 17 & (3.7) & (4.3) \\
\hline 18 & (3.7) & (4.3) \\
\hline 19 & (3.7) & (4.3) \\
\hline 20 & 3.7 & 4.3 \\
\hline 21 & (3.7) & (4.3) \\
\hline 22 & 3.6 & 4.3 \\
\hline 23 & (3.5) & (4.3) \\
\hline 24 & (3.0) & (4.3) \\
\hline 25 & (3.0) & (4.3) \\
\hline 26 & (3.0) & (4.3) \\
\hline 27 & 3.0 & 4.6 \\
\hline 28 & (3.0) & (3.0) \\
\hline 29 & 3.0 & 2.9 \\
\hline 30 & (3.0) & $(3.0)$ \\
\hline 31 & (3.0) & (3.0) \\
\hline
\end{tabular}

Total 114.1
January 1984

\begin{tabular}{|c|c|c|}
\hline Day & $\begin{array}{c}\text { Caisson } \\
\text { D }\end{array}$ & $\begin{array}{c}\text { Caisson } \\
\mathrm{C}\end{array}$ \\
\hline 1 & (2.9) & (2.9) \\
\hline 2 & (2.9) & (2.9) \\
\hline 3 & (2.9) & (2.9) \\
\hline 4 & 2.9 & 2.9 \\
\hline 5 & (2.9) & (2.9) \\
\hline 6 & (2.9) & (2.9) \\
\hline 7 & (2.9) & (2.9) \\
\hline 8 & $(2.9)$ & $(2.9)$ \\
\hline 9 & (2.9) & (2.9) \\
\hline 10 & 2.9 & 2.9 \\
\hline 11 & (2.5) & $(2.9)$ \\
\hline 12 & 2.3 & 2.9 \\
\hline 13 & (2.3) & (2.9) \\
\hline 14 & (2.3) & (2.9) \\
\hline 15 & $(2.2)$ & (2.9) \\
\hline 16 & (2.2) & (2.9) \\
\hline 17 & 2.2 & 2.9 \\
\hline 18 & (2.2) & (2.9) \\
\hline 19 & 2.2 & 2.9 \\
\hline 20 & (2.0) & (2.5) \\
\hline 21 & $(2.0)$ & (2.5) \\
\hline 22 & $(2.0)$ & $(2.0)$ \\
\hline 23 & (1.5) & (2.0) \\
\hline 24 & (1.5) & (1.5) \\
\hline 25 & (1.5) & (1.5) \\
\hline 26 & (1.0) & (1.5) \\
\hline 27 & (1.0) & (1.0) \\
\hline 28 & $(1.0)$ & $(1.0)$ \\
\hline 29 & $(1.0)$ & (1.0) \\
\hline 30 & (1.0) & (1.0) \\
\hline 31 & (1.0) & (1.0) \\
\hline Total & 65.9 & 73.6 \\
\hline
\end{tabular}

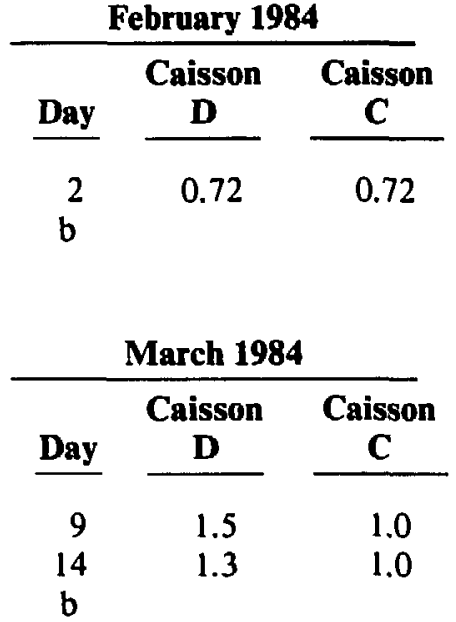

'Total through January

1474.1 \&-Caisson D

985.7 \&-Caisson C

'Rest of month

not measureo.

Note: Parentheses indicate estimated-not measured. 
January

1984

$\begin{array}{rr}1 & .04 \\ 4 & .11 \\ 15 & .03 \\ 17 & .01 \\ & \\ 24 & .01 \\ 25 & .06 \\ 26 & .08 \\ 27 & .09 \\ \text { Totals } & .43\end{array}$

Natural
Supplemental

Caisson C Caisson D 
APPENDIX C

Summary of Soil Moisture 
TABLE C-I

SUMMARY OF SOIL MOISTURE FOR THE 1982 FIELD SEASON IN CAISSON C ${ }^{\text {a }}$

(June 11, 1982 - March 14, 1983

(Fer Cent by Volume)

\begin{tabular}{|c|c|c|c|c|c|c|c|c|c|c|c|c|c|c|c|c|c|c|}
\hline \multirow{2}{*}{$\begin{array}{l}\text { Depth Below } \\
\text { Surface (cm) }\end{array}$} & \multicolumn{2}{|c|}{$6 / 11 / 82$} & \multicolumn{2}{|c|}{$8 / 9 / 82$} & \multicolumn{2}{|c|}{ 8/10/82 } & \multicolumn{2}{|c|}{ 9/17/82 (am) } & \multicolumn{2}{|c|}{$9 / 17 / 82(\mathrm{pm})$} & \multicolumn{2}{|c|}{$11 / 3 / 82$} & \multicolumn{2}{|c|}{$1 / 25 / 83$} & \multicolumn{2}{|c|}{$2 / 23 / 83$} & \multicolumn{2}{|c|}{$3 / 14 / 83$} \\
\hline & $\mathrm{C}_{2}$ & $\mathrm{C}_{1}$ & $\mathrm{C}_{2}$ & $\mathrm{C}_{1}$ & $\overline{C_{2}}$ & $\overline{C_{1}}$ & $\mathrm{C}_{2}$ & $\mathrm{C}_{1}$ & $\mathrm{C}_{2}$ & $\mathrm{C}_{1}$ & $\mathrm{C}_{2}$ & $\mathrm{C}_{1}$ & $\mathrm{C}_{2}$ & $\mathbf{C}_{1}$ & $\mathbf{C}_{2}$ & $C_{1}$ & $C_{2}$ & $\mathbf{C}_{1}$ \\
\hline 30.0 & $\overline{27.0}$ & $\overline{23.8}$ & 9.2 & 9.2 & $\overline{20.8}$ & 10.4 & $\overline{13.1}$ & $\overline{10.6}$ & $\overline{31.7}$ & $\overline{21.7}$ & $\overline{13.8}$ & 12.1 & $\overline{25.2}$ & 18.4 & 28.9 & 28.8 & 27.0 & 23.4 \\
\hline 60.5 & 18.1 & 15.8 & 8.3 & 8.1 & 9.2 & 7.8 & 9.2 & 8.1 & 11.0 & 8.7 & 12.7 & 10.7 & 15.1 & 11.1 & 22.9 & 24.2 & 20.1 & 19.3 \\
\hline 91.0 & 7.7 & 8.6 & 6.5 & 6.0 & 5.7 & 6.4 & 6.3 & 6.6 & 6.2 & 6.0 & 9.5 & 10.1 & 8.9 & 9.1 & 12.7 & 11.8 & 12.8 & 13.3 \\
\hline 121.5 & 7.3 & 8.3 & 7.4 & 8.3 & 7.7 & 8.9 & 7.3 & 7.1 & 7.4 & 6.9 & 10.1 & 10.6 & 8.7 & 9.0 & 8.8 & 8.2 & 11.7 & 12.0 \\
\hline 152.0 & 8.6 & 8.7 & 9.0 & 9.2 & 9.6 & 9.6 & 8.8 & 8.5 & 8.8 & 8.3 & 11.5 & 10.4 & 8.9 & 8.7 & 9.9 & 9.2 & 11.2 & 12.0 \\
\hline 182.5 & 14.7 & 14.5 & 14.5 & 13.3 & 13.9 & 13.2 & 12.1 & 13.7 & 13.1 & 13.0 & 14.5 & 13.7 & 13.3 & 13.4 & 13.7 & 13.5 & 14.3 & 14.0 \\
\hline 213.0 & 14.8 & 14.4 & 13.6 & 13.8 & 14.9 & 14.1 & 13.4 & 13.3 & 13.0 & 13.6 & 13.3 & 14.5 & 12.9 & 12.7 & 13.3 & 13.9 & 13.6 & 13.5 \\
\hline 271.0 & \multicolumn{2}{|c|}{-} & \multicolumn{2}{|c|}{-} & \multicolumn{2}{|c|}{14.3} & \multicolumn{2}{|c|}{13.9} & \multicolumn{2}{|c|}{13.7} & \multicolumn{2}{|c|}{15.0} & \multicolumn{2}{|c|}{14.8} & \multicolumn{2}{|c|}{15.0} & \multicolumn{2}{|c|}{15.5} \\
\hline 347.0 & \multicolumn{2}{|c|}{ - } & \multirow{2}{*}{\multicolumn{2}{|c|}{ - }} & \multirow{2}{*}{\multicolumn{2}{|c|}{13.1}} & \multirow{2}{*}{\multicolumn{2}{|c|}{13.0}} & \multirow{2}{*}{\multicolumn{2}{|c|}{13.0}} & \multicolumn{2}{|c|}{13.0} & \multicolumn{2}{|c|}{13.1} & \multicolumn{2}{|c|}{13.0} & \multicolumn{2}{|c|}{13.2} \\
\hline 422.0 & \multicolumn{2}{|c|}{ - } & & - & & 13.9 & & & & & \multicolumn{2}{|c|}{13.6} & 1 & & & & 13 & \\
\hline
\end{tabular}

${ }^{2} \mathrm{C}_{2}$ - center access hole

Note: 2" of water added between $8 / 9$ and $8 / 10 / 82$

$4 "$ of water added after noon on $9 / 17 / 82$ 


\section{TABLE C-II}

SUMMARY OF SOIL MOISTURE FOR THE 1982 FIELD SEASON IN CAISSON $\mathrm{D}^{\mathrm{a}}$

(Per Cent by Volume)

\begin{tabular}{|c|c|c|c|c|c|c|c|c|c|c|c|c|c|c|c|c|c|c|}
\hline \multirow{2}{*}{$\begin{array}{l}\text { Depth Below } \\
\text { Surface (cm) }\end{array}$} & \multicolumn{2}{|c|}{$6 / 11 / 82$} & \multicolumn{2}{|c|}{$8 / 9 / 82$} & \multicolumn{2}{|c|}{$8 / 10 / 82$} & \multicolumn{2}{|c|}{$9 / 17 / 82(\mathrm{am})$} & \multicolumn{2}{|c|}{$9 / 17 / 82(\mathrm{pm})$} & \multicolumn{2}{|c|}{$11 / 3 / 82$} & \multicolumn{2}{|c|}{$1 / 25 / 83$} & \multicolumn{2}{|c|}{$2 / 23 / 83$} & \multicolumn{2}{|c|}{$3 / 14 / 83$} \\
\hline & $\mathbf{D}_{\mathbf{1}}$ & $\mathbf{D}_{2}$ & $\mathbf{D}_{1}$ & $\mathbf{D}_{2}$ & $\mathbf{D}_{1}$ & $\mathbf{D}_{2}$ & $\mathbf{D}_{\mathbf{1}}$ & $\mathbf{D}_{2}$ & $\mathbf{D}_{\mathbf{1}}$ & $\underline{\mathbf{D}_{2}}$ & $\mathbf{D}_{1}$ & $\underline{\mathbf{D}_{2}}$ & $\mathrm{D}_{1}$ & $\underline{D_{2}}$ & $\underline{D_{1}}$ & $\underline{\mathbf{D}_{2}}$ & $\underline{\mathbf{D}_{1}}$ & $\underline{\mathbf{D}_{2}}$ \\
\hline 30.0 & 26.4 & 26.0 & 9.4 & 8.5 & 24.9 & 27.4 & 11.5 & 11.5 & 42.3 & 38.9 & 20.7 & 17.5 & 28.5 & 27.0 & 36.8 & 35.3 & 33.0 & 31.5 \\
\hline 60.5 & 16.5 & 18.0 & 9.6 & 8.9 & 9.1 & 10.0 & 8.8 & 8.9 & 29.8 & 23.0 & 14.8 & 13.3 & 16.2 & 16.8 & 22.2 & 25.9 & 21.7 & 21.7 \\
\hline 91.0 & 4.7 & 4.4 & 4.0 & 3.9 & 3.9 & 4.4 & 4.2 & 4.0 & 7.1 & 4.7 & 4.8 & 4.7 & 4.0 & 3.9 & 5.0 & 6.6 & 5.6 & 4.8 \\
\hline 121.5 & 2.6 & 2.7 & 2.9 & 2.6 & 2.7 & 2.9 & 2.5 & 2.7 & 2.8 & 2.8 & 2.9 & 2.7 & 2.5 & 2.6 & 2.5 & 3.6 & 3.2 & 4.0 \\
\hline 152.0 & 3.1 & 3.6 & 3.2 & $3: r_{s}$ & 3.8 & 3.5 & 3.5 & 3.3 & 4.9 & 4.9 & 3.9 & 3.8 & 4.3 & 3.1 & 4.1 & 4.1 & 4.1 & 3.8 \\
\hline 182.5 & 15.2 & 15.0 & 12.9 & 13.7 & 14.9 & 13.4 & 13.8 & 13.4 & 25.1 & 23.1 & 14.1 & 15.1 & 13.7 & 13.1 & 15.1 & 21.6 & 16.2 & 16.4 \\
\hline 213.0 & 16.4 & 16.8 & 15.3 & 14.9 & 14.9 & $15.6 \%$ & 14.6 & 14.9 & 13.9 & 14.1 & 15.2 & 16.2 & 14.2 & 13.7 & 14.7 & 17.7 & 16.6 & 16.8 \\
\hline 271.0 & \multicolumn{2}{|c|}{-} & \multicolumn{2}{|c|}{-} & \multicolumn{2}{|c|}{14.9} & \multicolumn{2}{|c|}{14.1} & \multicolumn{2}{|c|}{14.2} & \multicolumn{2}{|c|}{15.2} & \multicolumn{2}{|c|}{13.7} & \multicolumn{2}{|c|}{15.5} & \multicolumn{2}{|c|}{17.0} \\
\hline 347.0 & \multicolumn{2}{|c|}{-} & \multirow{2}{*}{\multicolumn{2}{|c|}{-}} & \multicolumn{2}{|c|}{16.5} & \multirow{2}{*}{\multicolumn{2}{|c|}{$\begin{array}{l}16.5 \\
153\end{array}$}} & \multicolumn{2}{|c|}{16.3} & \multicolumn{2}{|c|}{17.3} & \multicolumn{2}{|c|}{16.5} & \multicolumn{2}{|c|}{16.8} & \multicolumn{2}{|c|}{17.5} \\
\hline 422.0 & \multicolumn{2}{|c|}{ - } & & & \multicolumn{2}{|c|}{14.7} & & & \multicolumn{2}{|c|}{14.8} & \multicolumn{2}{|c|}{15.4} & 15 & & & .8 & & 0 \\
\hline
\end{tabular}

${ }^{a} D_{1}-$ center access hole

Note: $2^{\prime \prime}$ of water added between $8 / 9$ and $8 / 10 / 82$

$4 "$ of water added after noon on $9 / 17 / 82$ 
TABLE C.III

SUMMARY OF SOIL MOISTURE FOR THE 1983 FIELD SEASON IN CAISSON $C^{a}$ (Per Cent by Volume)

\begin{tabular}{|c|c|c|c|c|c|c|c|c|c|c|c|c|c|c|c|c|c|c|}
\hline \multirow{2}{*}{$\begin{array}{l}\text { Depth Below } \\
\text { Surface (cm) } \\
\end{array}$} & \multicolumn{2}{|c|}{$6 / 8 / 83$} & \multicolumn{2}{|c|}{$6 / 28 / 83$} & \multicolumn{2}{|c|}{$7 / 11 / 83$} & \multicolumn{2}{|c|}{$7 / 28 / 83$} & \multicolumn{2}{|c|}{$8 / 24 / 83$} & \multicolumn{2}{|c|}{$9 / 14 / 83$} & \multicolumn{2}{|c|}{$12 / 16 / 83$} & \multicolumn{2}{|c|}{$1 / 13 / 84$} & \multicolumn{2}{|c|}{$2 / 15 / 84$} \\
\hline & $\mathrm{C}_{2}$ & $\mathrm{C}_{1}$ & 5.2 & $C_{1}$ & $\mathrm{C}_{2}$ & $C_{1}$ & $\mathbf{C}_{2}$ & $C_{1}$ & $\mathrm{C}_{2}$ & $\mathrm{C}_{1}$ & $C_{2}$ & $\mathrm{C}_{1}$ & $\mathrm{C}_{2}$ & $\mathrm{C}_{1}$ & $\mathrm{C}_{2}$ & $\underline{C_{1}}$ & $C_{2}$ & $\underline{C_{1}}$ \\
\hline 17.5 & - & $\overline{11.7}$ & $\overline{17.6}$ & $\overline{15.5}$ & $\overline{13.9}$ & $\overline{14.8}$ & $\overline{23.6}$ & $\overline{22.2}$ & $\overline{27.9}$ & $\overline{24.0}$ & $\overline{28.4}$ & $\overline{25.8}$ & $\overline{17.9}$ & 17.3 & 24.9 & 23.7 & 27.1 & 25.4 \\
\hline 37.5 & - & 16.6 & 20.3 & 16.3 & 14.1 & 14.0 & 23.0 & 23.0 & 27.7 & 20.3 & 28.9 & 25.6 & 16.9 & 17.2 & 18.5 & 18.2 & 19.4 & 18.8 \\
\hline 57.5 & - & 16.3 & 17.2 & 15.8 & 13.2 & 14.3 & 16.5 & 20.5 & 21.2 & 16.7 & 23.8 & 21.3 & 12.3 & 13.7 & 13.4 & 14.7 & 13.7 & 14.4 \\
\hline 77.5 & - & 11.7 & 11.5 & 11.2 & 10.2 & 10.4 & 12.7 & 14.4 & 14.8 & 15.2 & 15.2 & 14.8 & 7.5 & 7.9 & 7.8 & 8.4 & 8.2 & 8.6 \\
\hline 97.5 & - & 11.5 & 10.6 & 10.8 & 9.9 & 10.4 & 11.2 & 12.9 & 13.2 & 15.2 & 13.9 & 14.9 & 7.2 & 7.9 & 7.7 & 8.2 & 8.2 & 8.5 \\
\hline 117.5 & - & 11.5 & 10.6 & 10.9 & 10.0 & 10.4 & 10.9 & 12.0 & 12.8 & 15.1 & 13.7 & 14.6 & 7.8 & 8.4 & 8.2 & 8.6 & 8.3 & 8.9 \\
\hline 137.5 & - & 12.2 & 11.4 & 11.4 & 11.0 & 11.0 & 11.4 & 12.0 & 14.0 & 15.6 & 14.9 & 15.7 & 9.1 & 9.0 & 9.0 & 9.4 & 9.0 & 9.3 \\
\hline 157.5 & 一 & 12.4 & 12.1 & 11.5 & 11.6 & 11.2 & 11.9 & 11.8 & 14.2 & 15.2 & 15.1 & 15.9 & 10.2 & 9.4 & 10.0 & 9.4 & 9.8 & 10.0 \\
\hline 177.5 & - & 15.7 & 15.0 & 15.3 & 14.6 & 14.7 & 14.6 & 14.8 & 17.6 & 19.0 & 19.0 & 20.8 & 13.2 & $12.8^{\prime}$ & 12.6 & 13.5 & 13.3 & 13.6 \\
\hline 197.5 & - & 16.4 & 15.4 & 15.7 & 14.9 & 15.1 & 15.0 & 15.5 & 17.7 & 18.7 & 19.1 & 20.4 & 13.0 & 13.7 & 13.7 & 14.0 & 13.8 & 14.1 \\
\hline 217.5 & - & 16.6 & 15.7 & 15.7 & 15.2 & 15.4 & 15.2 & 15.5 & 18.6 & 19.2 & 20.2 & 21.5 & 13.1 & 13.7 & 13.5 & 13.9 & 13.3 & 14.0 \\
\hline 271.0 & & & 15 & & & & & & - & & & & & .8 & & .1 & & \\
\hline 347.0 & & $i$ & 15 & & & & & & - & & & & & .1 & & 3.8 & & \\
\hline 422.0 & & & 16 & & & & & & - & & & & & & & 6.3 & & \\
\hline
\end{tabular}

${ }^{2} \mathrm{C}_{2}$ - center access hole 
TABLE C-IV

SUMMARY OF PERCENT VOLUMETRIC SOIL MOISTURE FOR 1983 FIELD SEASON IN CAISSON D* (Per Cent by Volume)

\begin{tabular}{|c|c|c|c|c|c|c|c|c|c|c|c|c|c|c|c|c|c|c|}
\hline \multirow{2}{*}{$\begin{array}{l}\text { Depth Below } \\
\text { Surface (cm) }\end{array}$} & \multicolumn{2}{|c|}{$6 / 8 / 83$} & \multicolumn{2}{|c|}{$6 / 28 / 83$} & \multicolumn{2}{|c|}{$7 / 11 / 83$} & \multicolumn{2}{|c|}{$7 / 28 / 83$} & \multicolumn{2}{|c|}{$8 / 24 / 83$} & \multicolumn{2}{|c|}{ 9/14/83 } & \multicolumn{2}{|c|}{$12 / 16 / 83$} & \multicolumn{2}{|c|}{$1 / 13 / 84$} & \multicolumn{2}{|c|}{$2 / 15 / 84$} \\
\hline & $\overline{D_{1}}$ & $\overline{D_{2}}$ & $\overline{\mathbf{D}_{1}}$ & $\overline{D_{2}}$ & $\overline{D_{1}}$ & $\overline{D_{2}}$ & $D_{1}$ & $\mathbf{D}_{2}$ & $\mathbf{D}_{1}$ & $\mathbf{D}_{2}$ & $\overline{D_{1}}$ & $\overline{D_{2}}$ & $\overline{D_{1}}$ & $\overline{D_{2}}$ & $\overline{D_{1}}$ & $\overline{D_{2}}$ & $\overline{D_{1}}$ & $\overline{D_{2}}$ \\
\hline 17.5 & - & $\overline{17.5}$ & $\overline{20.5}$ & 20.5 & 19.1 & 18.9 & 10.0 & 15.7 & $\overline{26.0}$ & 16.3 & 27.9 & 24.2 & 10.0 & 9.5 & 24.6 & - & 31.5 & 27.4 \\
\hline 37.5 & - & 25.5 & 26.4 & 25.2 & 16.2 & 17.9 & 16.1 & 14.8 & 28.1 & 15.4 & 32.1 & 22.8 & 11.2 & 10.8 & 24.6 & - & 26.4 & 22.2 \\
\hline 57.5 & - & 24.6 & 26.5 & 24.7 & 19.1 & 18.9 & 16.7 & 16.4 & 26.6 & 14.4 & 29.9 & 21.9 & 11.0 & 10.0 & 19.3 & - & 21.5 & 12.3 \\
\hline 77.5 & - & 7.5 & 7.5 & 7.4 & 7.5 & 6.7 & 8.1 & 8.1 & 7.7 & 6.3 & 8.1 & 7.2 & 5.2 & 4.9 & 5.8 & - & 6.3 & 5.5 \\
\hline 97.5 & - & 4.9 & 5.3 & 5.2 & 5.2 & 5.1 & 6.1 & 6.0 & 4.9 & 4.8 & 5.0 & 4.9 & 3.9 & 3.9 & 4.2 & - & 4.3 & 4.4 \\
\hline 117.5 & - & 3.8 & 3.6 & 3.8 & 3.5 & 3.8 & 4.8 & 5.0 & 3.6 & 3.8 & 3.7 & 3.7 & 3.2 & 3.1 & 3.4 & - & 3.7 & 3.3 \\
\hline 137.5 & - & 3.4 & 3.3 & 3.5 & 3.3 & 3.4 & 4.5 & 4.6 & 3.4 & 3.5 & 3.4 & 3.4 & 3.0 & 3.0 & 3.1 & - & 3.4 & 3.4 \\
\hline 157.5 & - & 4.9 & 5.8 & 5.3 & 5.9 & 5.2 & 7.1 & 6.5 & 5.9 & 5.9 & 6.6 & 5.7 & 5.6 & 5.2 & 5.9 & - & 5.8 & 5.3 \\
\hline 177.5 & - & 14.4 & 14.2 & 13.6 & 13.9 & 13.4 & 18.0 & 18.4 & 19.6 & 19.2 & 19.3 & 18.4 & 12.9 & 12.8 & 13.2 & - & 13.4 & 13.3 \\
\hline 197.5 & - & 14.9 & 14.2 & 14.3 & 15.8 & 13.8 & 19.4 & 19.4 & 21.5 & 20.3 & 19.5 & 19.1 & 13.0 & 13.5 & 13.4 & - & 13.4 & 14.0 \\
\hline 217.5 & - & 17.2 & 16.0 & 16.4 & 15.9 & 15.9 & 20.8 & 21.9 & 23.6 & 24.0 & 22.3 & 22.4 & 14.3 & 14.6 & 14.6 & - & 14.7 & 14.7 \\
\hline 271.0 & & .2 & 15 & & & & & & & & & & & & & & & .5 \\
\hline 347.0 & & .9 & 18 & & & & & & - & & & & & & & & & 6 \\
\hline 422.0 & & 6.7 & 17 & & & & & & ـ & & & & & & & & & .2 \\
\hline
\end{tabular}

${ }^{\mathrm{a}} D_{1}=$ center access hole. 
TABLE C.V

Caisson C. Horizontal Profiles \% Volumetric Moisture

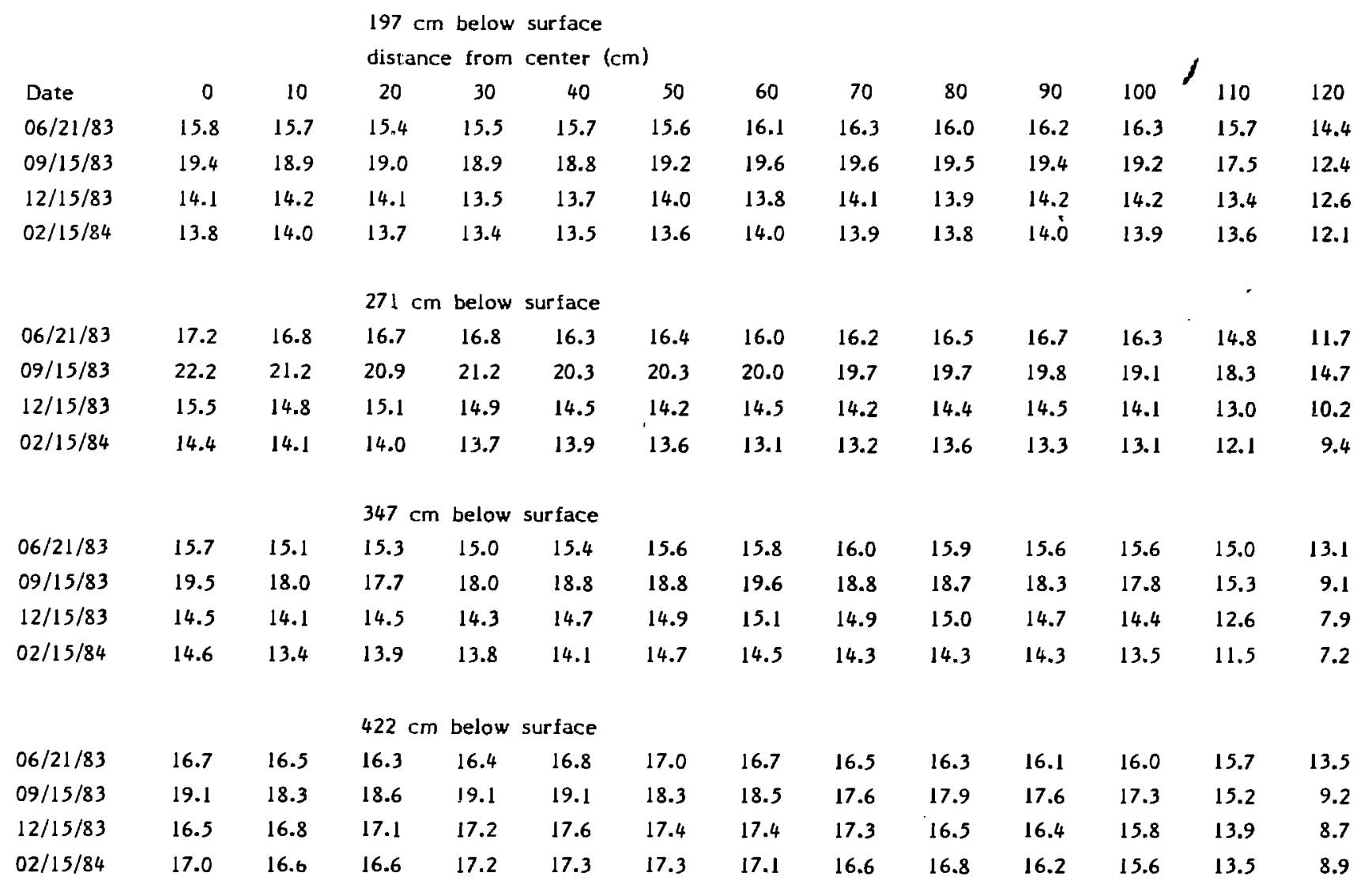


APPENDIX D

Volumetric Moisture Data 
Table D-I: Vertical Moisture for First Season (\% Moisture by Volume) Caisson C

\begin{tabular}{|c|c|c|c|c|c|c|c|c|c|}
\hline $\begin{array}{l}\text { Distance } \\
\text { From } \\
\text { Surface }\end{array}$ & $6 / 11 / 82$ & $6 / 14 / 82$ & $6 / 16 / 82$ & $6 / 21 / 82$ & $6 / 25 / 82$ & $6 / 30 / 82$ & $7 / 6 / 82$ & $1 / 8 / 82$ & $7 / 9 / 82$ \\
\hline $\begin{array}{l}\text { Hole } \\
C_{1}\end{array}$ & & & & & & & & $\cdot$ & \\
\hline $\begin{array}{r}213.0 \\
182.5 \\
152.0 \\
121.5 \\
91.0 \\
60.5 \\
30.0\end{array}$ & $\begin{array}{r}14.4^{4} \\
14.5 \\
8.7 \\
8.3 \\
8.6 \\
15.8 \\
23.8\end{array}$ & $\begin{array}{r}14.2 \\
14.3 \\
8.5 \\
8.5 \\
9.5 \\
17.8 \\
22.3\end{array}$ & $\begin{array}{r}14.1 \\
14.5 \\
8.7 \\
9.2 \\
9.6 \\
14.6 \\
20.6\end{array}$ & $\begin{array}{r}14.2 \\
14.0 \\
9.7 \\
10.1 \\
9.9 \\
13.4 \\
18.9\end{array}$ & $\begin{array}{r}13.9 \\
13.9 \\
10.2 \\
9.3 \\
9.1 \\
12.1 \\
15.7\end{array}$ & $\begin{array}{r}15.1 \\
14.9 \\
10.3 \\
9.7 \\
8.8 \\
11.6 \\
13.2\end{array}$ & $\begin{array}{r}15.2 \\
14.0 \\
9.9 \\
9.1 \\
8.3 \\
8.1 \\
11.3\end{array}$ & $\begin{array}{r}15.1 \\
14.2 \\
9.7 \\
9.6 \\
7.9 \\
8.4 \\
9.5\end{array}$ & $\begin{array}{r}14.1 \\
15.6 \\
10.0 \\
9.1 \\
7.9 \\
8.1 \\
9.2\end{array}$ \\
\hline \multicolumn{10}{|l|}{$\begin{array}{l}\text { Hole } \\
C_{2}\end{array}$} \\
\hline $\begin{array}{r}213.0 \\
182.5 \\
152.0 \\
121.5 \\
91.0 \\
60.5 \\
30.0\end{array}$ & $\begin{array}{r}14.8 \\
14.7 \\
8.6 \\
7.3 \\
7.7 \\
18.1 \\
27.0\end{array}$ & $\begin{array}{r}13.9 \\
14.6 \\
8.6 \\
7.9 \\
10.4 \\
20.4 \\
30.4\end{array}$ & $\begin{array}{r}13.4 \\
14.6 \\
9.5 \\
8.3 \\
10.2 \\
18.4 \\
24.9\end{array}$ & $\begin{array}{r}13.1 \\
14.4 \\
9.1 \\
9.4 \\
9.8 \\
15.1 \\
22.6\end{array}$ & $\begin{array}{r}15.1 \\
14.5 \\
9.7 \\
10.0 \\
9.8 \\
16.8 \\
24.4\end{array}$ & $\begin{array}{r}14.9 \\
14.7 \\
10.6 \\
10.1 \\
9.2 \\
17.4 \\
27.4\end{array}$ & $\begin{array}{r}15.4 \\
15.3 \\
10.6 \\
9.4 \\
8.1 \\
13.0 \\
28.4\end{array}$ & $\begin{array}{r}14.6 \\
14.1 \\
9.9 \\
9.0 \\
8.0 \\
11.8 \\
21.9\end{array}$ & $\begin{array}{r}15.2 \\
15.1 \\
9.7 \\
8.7 \\
7.9 \\
11.8 \\
17.2\end{array}$ \\
\hline
\end{tabular}


Table D-I (cont)

\begin{tabular}{|c|c|c|c|c|c|c|c|c|c|c|}
\hline $\begin{array}{l}\text { Distance } \\
\text { Frús }\end{array}$ & & & & & Date & & & & & \\
\hline$\frac{\text { Surface }}{(\mathrm{cm})}$ & $7 / 12 / 82$ & $7 / 15 / 82$ & $7 / 16 / 82$ & $7 / 19 / 82$ & $7 / 23 / 82$ & $7 / 26 / 82$ & $7 / 27 / 82$ & $7 / 28 / 82$ & $7 / 29 / 82$ & $7 / 30 / 82$ \\
\hline
\end{tabular}

Hole

$\mathrm{C}_{1}$

$\begin{array}{lllllllllll}213.0 & 14.3 & 14.9 & 14.7 & 14.2 & 14.5 & 14.3 & 13.5 & 14.2 & 14.5 & 13.6\end{array}$

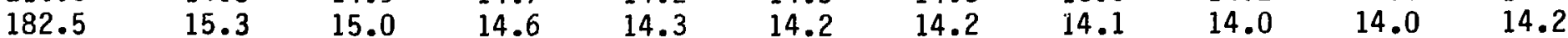

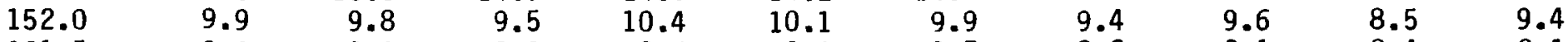

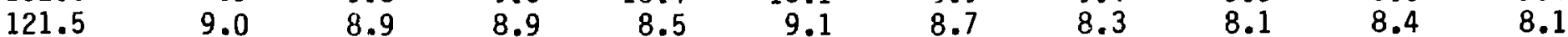

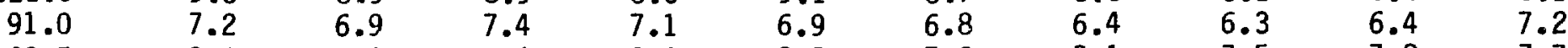

$\begin{array}{lllllllllll}60.5 & 8.4 & 8.8 & 8.4 & 8.9 & 8.3 & 7.2 & 8.1 & 7.5 & 7.8 & 7.7\end{array}$

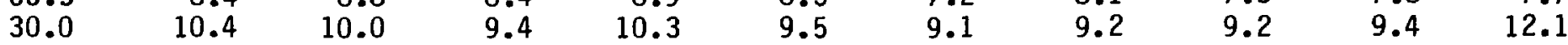

Hole

$\mathrm{C}_{2}$

$\begin{array}{rrrrrrrrrrr}213.0 & 15.2 & 13.8 & 14.2 & 14.2 & 13.9 & 14.6 & 14.1 & 14.5 & 13.9 & 13.8 \\ 182.5 & 14.6 & 15.3 & 14.9 & 14.9 & 14.7 & 13.6 & 13.6 & 13.8 & 14.2 & 14.9 \\ 152.0 & 10.3 & 10.1 & 9.9 & 9.8 & 9.7 & 9.0 & 10.1 & 8.8 & 10.1 & 9.2 \\ 121.5 & 8.8 & 8.9 & 8.2 & 8.7 & 9.0 & 8.4 & 8.6 & 8.2 & 7.9 & 7.9 \\ 91.0 & 7.4 & 8.2 & 7.3 & 7.8 & 7.0 & 6.8 & 6.4 & 7.0 & 6.9 & 6.8 \\ 60.5 & 10.5 & 11.2 & 10.5 & 10.9 & 11.1 & 9.1 & 9.0 & 8.3 & 8.6 & 8.5 \\ 30.0 & 20.6 & 18.4 & 14.9 & 18.0 & 12.5 & 12.2 & 11.4 & 11.0 & 11.2 & 13.7\end{array}$




\begin{tabular}{|c|c|c|c|c|c|c|c|c|c|c|c|}
\hline $\begin{array}{l}\text { Distance } \\
\text { From } \\
\text { Surface }\end{array}$ & $8 / 2 / 82$ & $8 / 3 / 82$ & $8 / 4 / 82$ & $\begin{array}{r}(2-i n \\
8 / 6 / 82 \\
\end{array}$ & $\begin{array}{l}\text { Water } \\
8 / 9 / 82 \\
\end{array}$ & $\begin{array}{c}\text { Date } \\
\text { Suppl emen } \\
8 / 9 / 82 \\
\end{array}$ & $\begin{array}{r}\text { on } 8 / 9 / \\
8 / 10 / 82 \\
\end{array}$ & $\begin{array}{l}82) \\
8 / 11 / 82 \\
\end{array}$ & $8 / 12 / 82$ & $8 / 13 / 82$ & $8 / 16 / 82$ \\
\hline \multicolumn{12}{|l|}{$\begin{array}{l}\text { Hole } \\
c_{1}\end{array}$} \\
\hline $\begin{array}{r}213.0 \\
182.5 \\
15.20 \\
121.5 \\
91.0 \\
60.5 \\
30.0\end{array}$ & $\begin{array}{r}15.3 \\
14.0 \\
9.7 \\
8.7 \\
6.4 \\
8.1 \\
12.5\end{array}$ & $\begin{array}{r}14.7 \\
14.4 \\
9.2 \\
7.9 \\
6.8 \\
7.8 \\
11.5\end{array}$ & $\begin{array}{r}14.0 \\
14.4 \\
9.4 \\
8.4 \\
6.5 \\
7.4 \\
10.9\end{array}$ & $\begin{array}{r}13.9 \\
13.4 \\
9.1 \\
8.3 \\
6.7 \\
7.8 \\
10.0\end{array}$ & $\begin{array}{r}13.8 \\
13.3 \\
9.2 \\
8.3 \\
6.0 \\
8.1 \\
9.2\end{array}$ & $\begin{array}{r}14.5 \\
14.1 \\
9.6 \\
8.4 \\
6.1 \\
7.2 \\
10.5\end{array}$ & $\begin{array}{r}14.1 \\
13.2 \\
9.6 \\
8.9 \\
6.4 \\
7.8 \\
10.4\end{array}$ & $\begin{array}{r}13.9 \\
14.0 \\
8.9 \\
8.4 \\
6.6 \\
7.8 \\
10.9\end{array}$ & $\begin{array}{r}14.0 \\
14.1 \\
9.0 \\
7.8 \\
5.9 \\
7.5 \\
10.1\end{array}$ & $\begin{array}{r}13.9 \\
13.4 \\
8.3 \\
8.1 \\
5.6 \\
7.9 \\
9.5\end{array}$ & $\begin{array}{r}13.9 \\
14.1 \\
9.1 \\
8.3 \\
6.0 \\
6.6 \\
9.2\end{array}$ \\
\hline \multicolumn{12}{|l|}{$\begin{array}{l}\text { Hole } \\
C_{2}\end{array}$} \\
\hline $\begin{array}{r}213.0 \\
182.5 \\
152.0 \\
121.5 \\
91.0 \\
60.5 \\
30.0\end{array}$ & $\begin{array}{r}13.5 \\
13.6 \\
9.3 \\
8.5 \\
8.0 \\
9.0 \\
13.2\end{array}$ & $\begin{array}{r}13.7 \\
14.3 \\
9.5 \\
8.1 \\
6.9 \\
8.5 \\
11.9\end{array}$ & $\begin{array}{r}13.8 \\
14.2 \\
9.2 \\
8.1 \\
6.4 \\
8.7 \\
12.0\end{array}$ & $\begin{array}{r}14.1 \\
14.4 \\
8.3 \\
7.7 \\
6.8 \\
8.1 \\
10.7\end{array}$ & $\begin{array}{r}13.6 \\
14.5 \\
9.0 \\
7.4 \\
6.5 \\
8.3 \\
9.2\end{array}$ & $\begin{array}{r}14.4 \\
13.5 \\
9.2 \\
8.3 \\
6.7 \\
8.1 \\
20.1\end{array}$ & $\begin{array}{r}14.9 \\
13.9 \\
9.6 \\
7.7 \\
5.7 \\
9.2 \\
20.8\end{array}$ & $\begin{array}{r}14.2 \\
13.8 \\
9.0 \\
7.4 \\
6.4 \\
10.5 \\
20.0\end{array}$ & $\begin{array}{r}13.5 \\
14.1 \\
8.3 \\
7.3 \\
6.0 \\
9.0 \\
19.0\end{array}$ & $\begin{array}{r}13.1 \\
13.5 \\
9.5 \\
7.1 \\
6.0 \\
9.1 \\
18.3\end{array}$ & $\begin{array}{r}14.3 \\
14.3 \\
8.5 \\
7.7 \\
6.3 \\
8.7 \\
15.2\end{array}$ \\
\hline
\end{tabular}


Table D-I (cont)

\begin{tabular}{|c|c|c|c|c|c|c|c|c|c|}
\hline $\begin{array}{l}\text { Distance } \\
\text { From } \\
\text { Surface }\end{array}$ & $8 / 17 / 82$ & $8 / 18 / 82$ & $8 / 20 / 82$ & $8 / 23 / 82$ & $8 / 25 / 82$ & $8 / 30 / 82$ & $9 / 3 / 82$ & $9 / 7 / 82$ & $9 / 10 / 82$ \\
\hline \multicolumn{10}{|l|}{$\begin{array}{l}\text { Hole } \\
C_{1}\end{array}$} \\
\hline $\begin{array}{r}213.0 \\
182.5 \\
152.0 \\
121.5 \\
91.0 \\
60.5 \\
30.0\end{array}$ & $\begin{array}{r}13.9 \\
14.2 \\
9.0 \\
7.8 \\
6.1 \\
6.9 \\
9.5\end{array}$ & $\begin{array}{r}14.2 \\
13.9 \\
9.0 \\
8.1 \\
6.1 \\
6.7 \\
9.6\end{array}$ & $\begin{array}{r}13.5 \\
13.7 \\
9.0 \\
7.9 \\
5.6 \\
7.3 \\
9.5\end{array}$ & $\begin{array}{r}14.1 \\
13.7 \\
8.1 \\
7.5 \\
6.3 \\
6.8 \\
9.9\end{array}$ & $\begin{array}{r}13.6 \\
13.6 \\
8.9 \\
8.3 \\
6.5 \\
7.4 \\
12.0\end{array}$ & $\begin{array}{r}13.9 \\
13.6 \\
8.4 \\
7.8 \\
6.3 \\
7.5 \\
11.5\end{array}$ & $\begin{array}{r}13.7 \\
13.4 \\
8.2 \\
7.2 \\
5.9 \\
7.4 \\
11.1\end{array}$ & $\begin{array}{r}13.7 \\
13.6 \\
9.0 \\
7.0 \\
6.3 \\
7.8 \\
9.9\end{array}$ & $\begin{array}{r}13.7 \\
12.8 \\
8.8 \\
7.5 \\
6.2 \\
7.8 \\
9.5\end{array}$ \\
\hline \multicolumn{10}{|l|}{$\begin{array}{l}\text { Hole } \\
\mathrm{C}_{2}\end{array}$} \\
\hline $\begin{array}{r}213.0 \\
182.5 \\
152.0 \\
121.5 \\
91.0 \\
60.5 \\
30.0\end{array}$ & $\begin{array}{r}13.6 \\
13.7 \\
8.8 \\
7.8 \\
6.6 \\
9.6 \\
14.9\end{array}$ & $\begin{array}{r}13.5 \\
13.9 \\
8.9 \\
7.8 \\
6.7 \\
8.8 \\
14.1\end{array}$ & $\begin{array}{r}12.8 \\
13.2 \\
9.0 \\
7.0 \\
6.8 \\
9.0 \\
12.2\end{array}$ & $\begin{array}{r}13.0 \\
13.7 \\
8.9 \\
8.0 \\
6.8 \\
8.6 \\
13.4\end{array}$ & $\begin{array}{r}13.8 \\
13.5 \\
8.7 \\
8.2 \\
6.9 \\
9.2 \\
15.9\end{array}$ & $\begin{array}{r}12.9 \\
13.3 \\
8.6 \\
7.3 \\
6.5 \\
3.9 \\
14.0\end{array}$ & $\begin{array}{r}12.3 \\
13.7 \\
9.2 \\
7.4 \\
6.6 \\
9.4 \\
12.6\end{array}$ & $\begin{array}{r}13.6 \\
13.5 \\
9.0 \\
7.6 \\
6.7 \\
9.0 \\
11.2\end{array}$ & $\begin{array}{r}13.7 \\
13.5 \\
9.0 \\
6.8 \\
6.5 \\
8.7 \\
11.2\end{array}$ \\
\hline
\end{tabular}


Table D-I (cont)

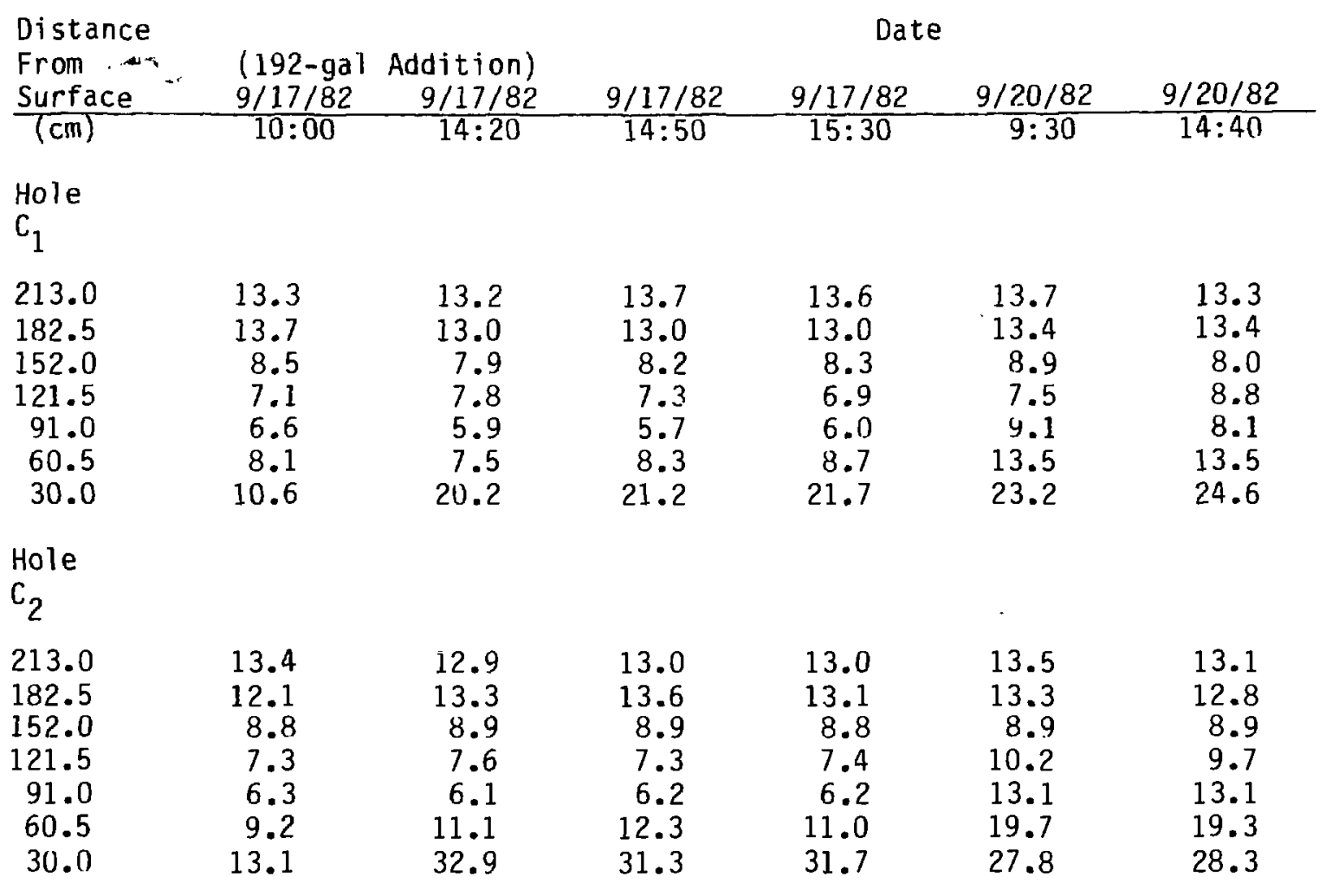




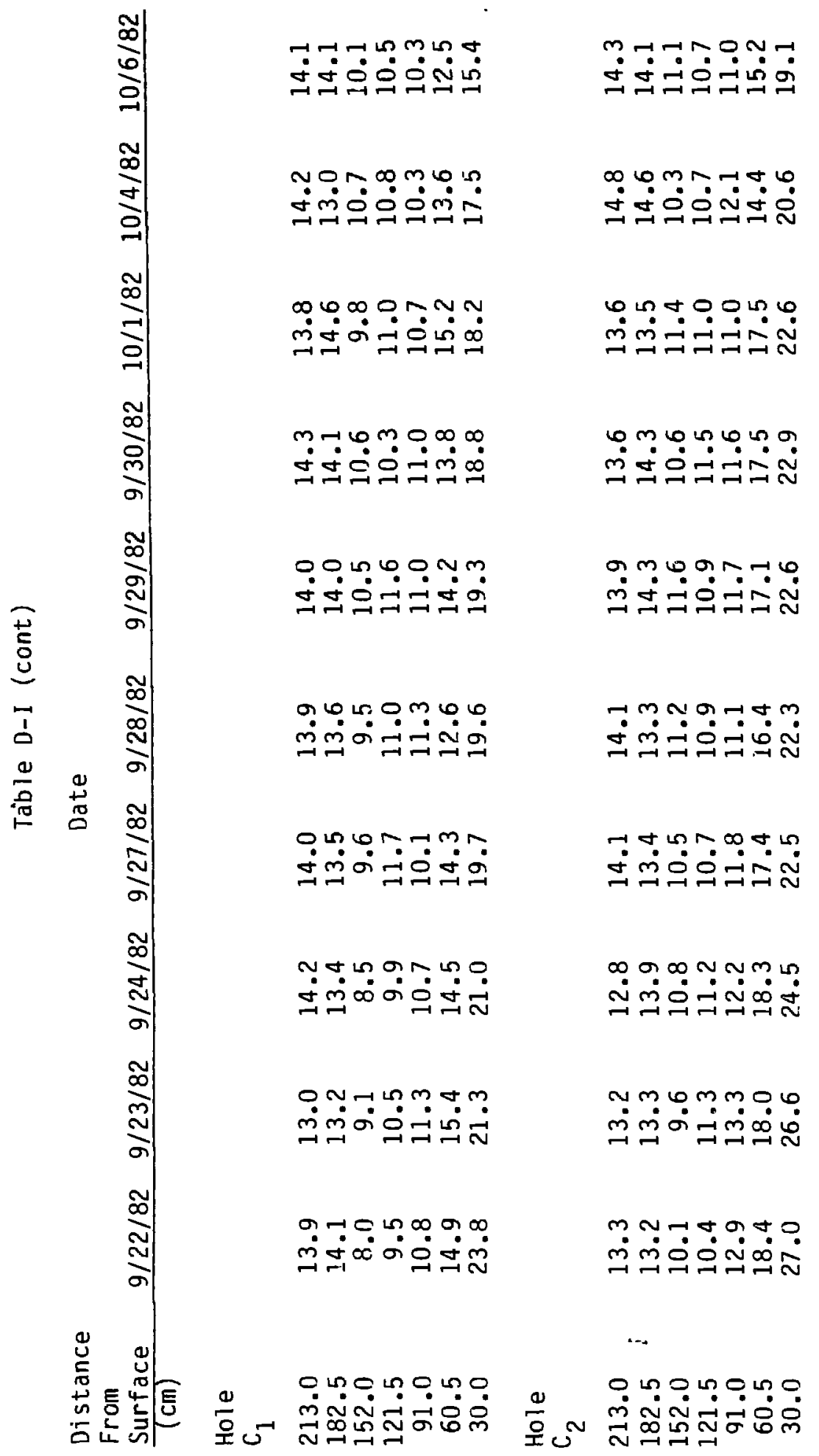


Table D-I (cont)

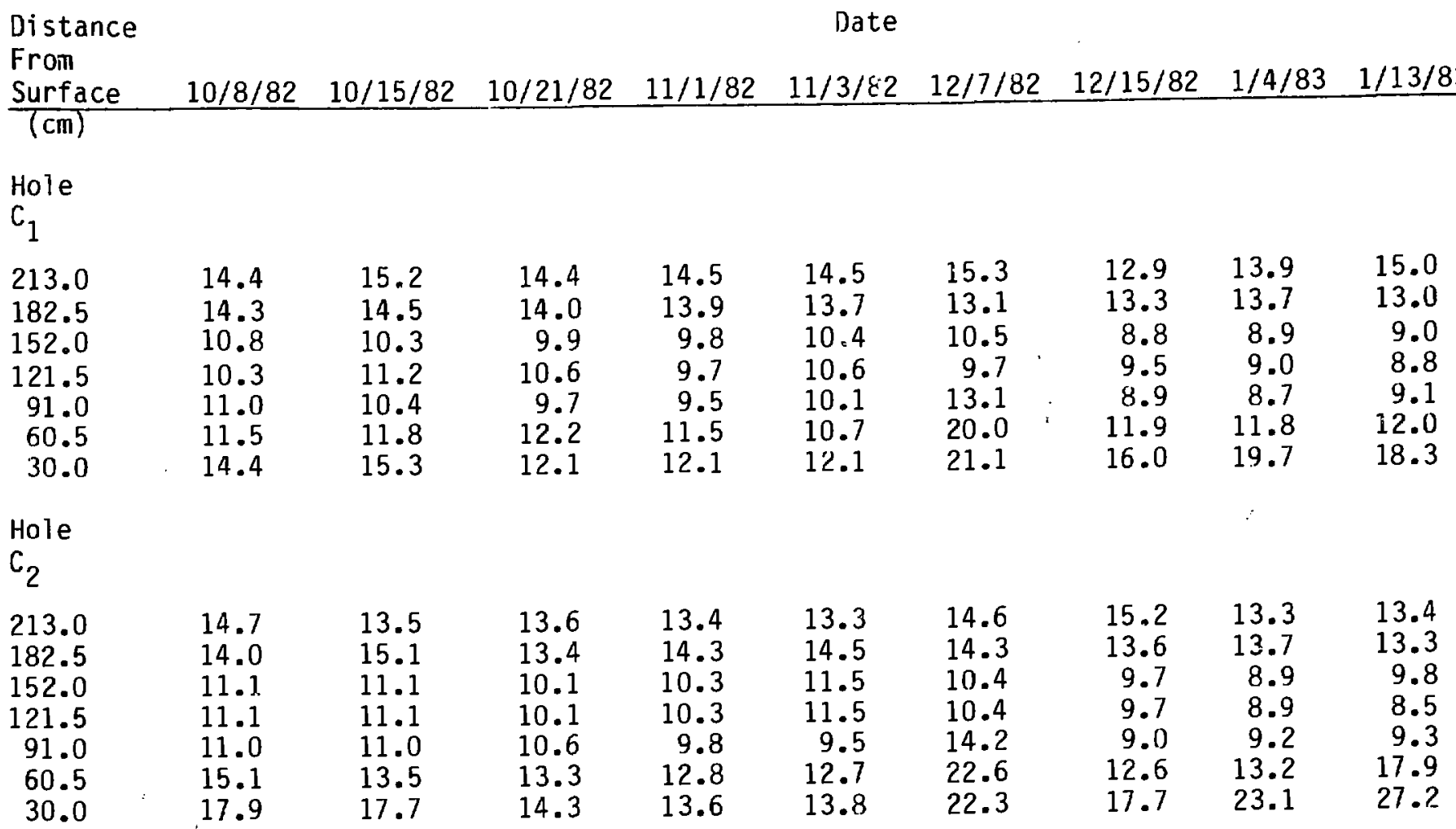


Table D-I (cont)

\begin{tabular}{lrrrrr}
$\begin{array}{l}\text { Distance } \\
\text { From } \\
\text { Surface }\end{array}$ & $1 / 25 / 83$ & $2 / 9 / 83$ & $2 / 23 / 83$ & $3 / 7 / 83$ & $3 / 14 / 83$ \\
\hline (cm) & & & & \\
Hole & & & & & \\
$C_{1}$ & & & & & \\
213.0 & 12.7 & 13.2 & 13.9 & 13.8 & 13.5 \\
182.5 & 13.4 & 13.4 & 13.5 & 14.3 & 14.0 \\
152.0 & 8.7 & 8.8 & 9.2 & 10.6 & 12.0 \\
121.5 & 9.0 & 9.0 & 8.2 & 11.4 & 12.0 \\
91.0 & 9.1 & 8.9 & 11.8 & 13.1 & 13.3 \\
60.5 & 11.1 & 11.1 & 24.2 & 23.0 & 19.3 \\
30.0 & 18.4 & 18.1 & 28.8 & 25.9 & 23.4 \\
& & & & & \\
$H o 1 e$ & & & & & \\
$C_{2}$ & & & & & \\
213.0 & 12.9 & 12.7 & 13.3 & 13.0 & 13.6 \\
182.5 & 13.3 & 12.6 & 13.7 & 13.8 & 14.3 \\
152.0 & 8.9 & 9.4 & 9.9 & 10.4 & 11.2 \\
121.5 & 8.7 & 9.6 & 8.8 & 11.3 & 11.7 \\
91.0 & 8.9 & 8.6 & 12.7 & 12.3 & 12.8 \\
60.5 & 15.1 & 13.4 & 22.9 & 21.2 & 20.1 \\
30.0 & 25.2 & 23.6 & 28.9 & 29.1 & 27.0 \\
& & & & &
\end{tabular}


(\% Moisture by Volume)

\begin{tabular}{|c|c|c|c|c|c|c|c|c|c|}
\hline $\begin{array}{l}\text { Distance } \\
\text { From } \\
\text { Surface }\end{array}$ & $6 / 11 / 82$ & $6 / 14 / 82$ & $6 / 16 / 82$ & $6 / 21 / 82$ & $6 / 25 / 82$ & $6 / 30 / 82$ & $7 / 6 / 82$ & $7 / 8 / 82$ & $7 / 9 / 8$ \\
\hline $\begin{array}{l}\text { (cm) } \\
\text { Hole } \\
D_{1}\end{array}$ & & & & & & & & & \\
\hline $\begin{array}{r}213.0 \\
182.5 \\
152.0 \\
121.5 \\
91.0 \\
60.5 \\
30.0\end{array}$ & $\begin{array}{r}16.4 \\
15.2 \\
3.1 \\
2.6 \\
4.7 \\
16.5 \\
26.4\end{array}$ & $\begin{array}{r}17.5 \\
15.1 \\
3.6 \\
2.7 \\
5.1 \\
20.9 \\
25.4\end{array}$ & $\begin{array}{r}16.2 \\
15.1 \\
3.9 \\
2.4 \\
4.6 \\
18.7 \\
24.2\end{array}$ & $\begin{array}{r}15.9 \\
14.1 \\
3.3 \\
3.0 \\
4.3 \\
16.8 \\
23.2\end{array}$ & $\begin{array}{r}15.5 \\
13.8 \\
3.0 \\
2.6 \\
4.6 \\
17.2 \\
22.2\end{array}$ & $\begin{array}{r}16.8 \\
14.9 \\
4.2 \\
3.0 \\
4.9 \\
10.3 \\
16.9\end{array}$ & $\begin{array}{r}15.5 \\
15.2 \\
3.8 \\
2.7 \\
4.1 \\
9.9 \\
15.1\end{array}$ & $\begin{array}{r}15.8 \\
14.4 \\
3.4 \\
3.0 \\
4.2 \\
9.6 \\
11.6\end{array}$ & $\begin{array}{r}15.9 \\
14.8 \\
3.7 \\
2.6 \\
4.6 \\
9.9 \\
9.5\end{array}$ \\
\hline $\begin{array}{l}\text { Hole } \\
\mathrm{D}_{2}\end{array}$ & & & & & & & & & \\
\hline $\begin{array}{r}213.0 \\
182.5 \\
152.0 \\
121.5 \\
91.0 \\
60.5 \\
30.0\end{array}$ & $\begin{array}{r}16.8 \\
15.0 \\
3.6 \\
2.7 \\
4.1 \\
18.0 \\
26.0\end{array}$ & $\begin{array}{r}16.4 \\
15.4 \\
3.6 \\
2.5 \\
5.0 \\
23.0 \\
25.3\end{array}$ & $\begin{array}{r}16.5 \\
14.4 \\
2.8 \\
2.7 \\
4.4 \\
23.3 \\
22 . ?\end{array}$ & $\begin{array}{r}16.8 \\
13.6 \\
3.1 \\
2.9 \\
4.5 \\
22.0 \\
24.1\end{array}$ & $\begin{array}{r}15.6 \\
13.9 \\
4.0 \\
2.7 \\
5.0 \\
14.4 \\
21.7\end{array}$ & $\begin{array}{r}16.2 \\
14.5 \\
4.0 \\
3.0 \\
4.4 \\
12.5 \\
17.9\end{array}$ & $\begin{array}{r}16.3 \\
15.0 \\
3.4 \\
3.0 \\
3.9 \\
9.3 \\
12.1\end{array}$ & $\begin{array}{r}16.0 \\
15.3 \\
3.7 \\
2.6 \\
3.7 \\
10.7 \\
11.0\end{array}$ & $\begin{array}{r}15.8 \\
14.9 \\
3.4 \\
2.6 \\
4.1 \\
9.7 \\
10.4\end{array}$ \\
\hline
\end{tabular}


Table D-II (cont)

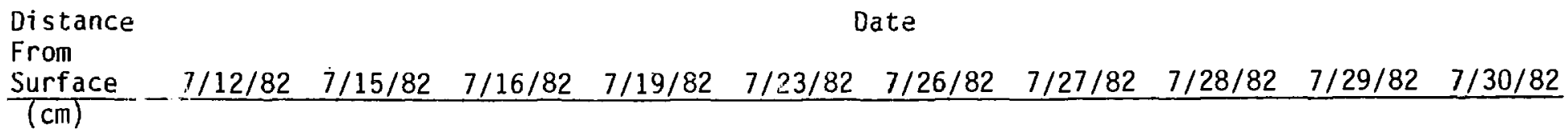

Hole

$\mathrm{D}_{1}$

\begin{tabular}{|c|c|c|c|c|c|c|c|c|c|c|}
\hline $\begin{array}{r}213.1 \\
182.5 \\
152.0 \\
121.5 \\
91.0 \\
60.5 \\
30.0\end{array}$ & $\begin{array}{r}16.8 \\
15.1 \\
3.5 \\
2.6 \\
3.7 \\
10.7 \\
14.0\end{array}$ & $\begin{array}{r}15.9 \\
13.9 \\
3.7 \\
2.8 \\
4.1 \\
8.9 \\
11.2\end{array}$ & $\begin{array}{r}14.8 \\
14.8 \\
3.4 \\
2.7 \\
4.1 \\
9.8 \\
11.1\end{array}$ & $\begin{array}{r}16.9 \\
14.3 \\
3.8 \\
2.4 \\
4.1 \\
9.3 \\
14.9\end{array}$ & $\begin{array}{r}15.5 \\
13.7 \\
3.6 \\
3.1 \\
4.1 \\
9.5 \\
10.6\end{array}$ & $\begin{array}{r}15.3 \\
14.0 \\
4.0 \\
3.0 \\
4.5 \\
9.0 \\
9.5\end{array}$ & $\begin{array}{r}15.3 \\
14.2 \\
3.2 \\
2.8 \\
3.7 \\
9.0 \\
9.7\end{array}$ & $\begin{array}{r}15.6 \\
14.6 \\
4.4 \\
2.5 \\
4.2 \\
9.2 \\
9.8\end{array}$ & $\begin{array}{r}15.3 \\
14.2 \\
3.7 \\
2.5 \\
4.0 \\
8.9 \\
10.0\end{array}$ & $\begin{array}{r}15.7 \\
13.5 \\
3.5 \\
2.9 \\
3.7 \\
9.1 \\
13.9\end{array}$ \\
\hline
\end{tabular}

$\mathrm{Hole}$

$\mathrm{D}_{2}$

$\begin{array}{rrrrrrrrrrr}213.0 & 16.4 & 15.7 & 16.3 & 16.7 & 16.7 & 16.1 & 15.5 & 16.3 & 14.9 & 15.2 \\ 182.5 & 14.5 & 14.4 & 14.0 & 13.9 & 14.8 & 13.3 & 13.4 & 13.6 & 13.8 & 13.4 \\ 152.0 & 3.9 & 3.5 & 3.0 & 3.1 & 3.2 & 2.9 & 3.4 & 3.5 & 3.4 & 2.9 \\ 121.5 & 2.2 & 2.9 & 3.1 & 2.9 & 3.1 & 2.7 & 2.5 & 2.4 & 2.8 & 2.7 \\ 91.0 & 4.1 & 4.2 & 4.2 & 4.1 & 4.3 & 3.7 & 3.8 & 3.8 & 3.7 & 4.1 \\ 60.5 & 9.1 & 10.9 & 9.1 & 9.7 & 10.9 & 9.2 & 9.0 & 9.2 & 8.9 & 9.6 \\ 30.0 & 11.8 & 11.3 & 10.5 & 11.7 & 9.8 & 11.1 & 9.9 & 10.8 & 9.7 & 11.9\end{array}$




\begin{tabular}{|c|c|c|c|c|c|c|c|c|c|c|c|}
\hline $\begin{array}{l}\text { Distance } \\
\text { From } \\
\text { Surface }\end{array}$ & $8 / 2 / 82$ & $8 / 3 / 82$ & $8 / 4 / 82$ & $8 / 6 / 82$ & $\begin{array}{l}\text { Two in } \\
8 / 9 / 82 \\
\end{array}$ & $\begin{array}{r}\text { Date } \\
\text { ches of } \\
8 / 9 / 82 \\
\end{array}$ & $\begin{array}{l}\text { water } \\
8 / 10 / 82 \\
\end{array}$ & $8 / 11 / 82$ & $8 / 12 / 82$ & $8 / 13 / 82$ & $8 / 16 / 82$ \\
\hline $\begin{array}{l}\text { (cm) } \\
\text { Hole } \\
D_{1}\end{array}$ & & & & & & & & & & & \\
\hline $\begin{array}{r}213.0 \\
182.5 \\
152.0 \\
121.5 \\
91.0 \\
60.5 \\
30.0\end{array}$ & $\begin{array}{r}15.1 \\
14.3 \\
3.2 \\
2.6 \\
4.0 \\
9.7 \\
13.7\end{array}$ & $\begin{array}{r}15.2 \\
14.4 \\
3.2 \\
2.8 \\
4.0 \\
8.7 \\
12.2\end{array}$ & $\begin{array}{r}15.9 \\
14.5 \\
3.7 \\
2.6 \\
4.0 \\
9.3 \\
12.0\end{array}$ & $\begin{array}{r}14.3 \\
13.6 \\
3.7 \\
3.0 \\
4.3 \\
8.3 \\
9.8\end{array}$ & $\begin{array}{r}15.3 \\
12.5 \\
3.2 \\
2.9 \\
4.0 \\
9.6 \\
9.4\end{array}$ & $\begin{array}{r}15.4 \\
14.3 \\
4.0 \\
2.7 \\
4.0 \\
7.7 \\
24.6\end{array}$ & $\begin{array}{r}14.9 \\
14.9 \\
3.8 \\
2.7 \\
3.9 \\
9.1 \\
24.9\end{array}$ & $\begin{array}{r}15.0 \\
14.3 \\
3.5 \\
2.8 \\
3.5 \\
9.4 \\
23.4\end{array}$ & $\begin{array}{r}15.5 \\
14.3 \\
3.5 \\
2.4 \\
3.8 \\
8.9 \\
21.2\end{array}$ & $\begin{array}{r}15.7 \\
14.4 \\
3.7 \\
2.8 \\
4.0 \\
9.7 \\
20.0\end{array}$ & $\begin{array}{r}14.9 \\
14.3 \\
3.9 \\
2.7 \\
3.5 \\
8.7 \\
15.2\end{array}$ \\
\hline $\begin{array}{l}\text { Hole } \\
D_{2}\end{array}$ & & & & & & & & & & & \\
\hline $\begin{array}{r}213.0 \\
182.5 \\
152.0 \\
121.5 \\
91.0 \\
60.5 \\
30.0\end{array}$ & $\begin{array}{r}16.5 \\
13.6 \\
3.1 \\
2.8 \\
3.7 \\
9.7 \\
12.3\end{array}$ & $\begin{array}{r}15.0 \\
13.6 \\
3.2 \\
2.7 \\
4.3 \\
9.2 \\
11.2\end{array}$ & $\begin{array}{r}16.2 \\
13.3 \\
3.4 \\
2.7 \\
3.8 \\
10.2 \\
10.4\end{array}$ & $\begin{array}{r}15.8 \\
14.6 \\
3.1 \\
2.5 \\
3.8 \\
8.8 \\
9.4\end{array}$ & $\begin{array}{r}14.9 \\
13.7 \\
3.0 \\
2.6 \\
3.9 \\
8.9 \\
8.5\end{array}$ & $\begin{array}{r}15.4 \\
14.2 \\
3.1 \\
2.7 \\
4.0 \\
9.3 \\
32.3\end{array}$ & $\begin{array}{r}15.6 \\
13.4 \\
3.5 \\
2.9 \\
4.4 \\
10.0 \\
27.4\end{array}$ & $\begin{array}{r}16.0 \\
13.3 \\
3.3 \\
3.0 \\
4.0 \\
13.6 \\
24.2\end{array}$ & $\begin{array}{r}15.3 \\
13.8 \\
2.7 \\
2.5 \\
3.8 \\
12.0 \\
23.1\end{array}$ & $\begin{array}{r}16.0 \\
13.3 \\
3.1 \\
2.8 \\
3.7 \\
13.2 \\
22.1\end{array}$ & $\begin{array}{r}15.2 \\
13.9 \\
3.2 \\
2.5 \\
3.7 \\
10.7 \\
17.5\end{array}$ \\
\hline
\end{tabular}


Table D-II (Cont)

\begin{tabular}{|c|c|c|c|c|c|c|c|c|c|}
\hline $\begin{array}{l}\text { Distance } \\
\text { From } \\
\text { Surface }\end{array}$ & $8 / 17 / 82$ & $8 / 18 / 82$ & $8 / 20 / 82$ & $8 / 23 / 82$ & $8 / 25 / 82$ & $8 / 30 / 82$ & $9 / 3 / 82$ & $9 / 7 / 82$ & $9 / 10 / 82$ \\
\hline $\begin{array}{l}\text { (cm) } \\
\text { Hole } \\
D_{1}\end{array}$ & & & & & & & & & \\
\hline $\begin{array}{r}213.0 \\
182.5 \\
152.0 \\
121.5 \\
91.0 \\
60.5 \\
30.0\end{array}$ & $\begin{array}{r}16.0 \\
14.0 \\
3.6 \\
2.6 \\
3.6 \\
8.1 \\
17.0\end{array}$ & $\begin{array}{r}15.1 \\
14.0 \\
3.8 \\
2.6 \\
3.8 \\
8.9 \\
15.7\end{array}$ & $\begin{array}{r}14.7 \\
13.2 \\
3.2 \\
2.6 \\
3.6 \\
9.1 \\
14.8\end{array}$ & $\begin{array}{r}14.5 \\
13.3 \\
3.9 \\
2.8 \\
4.1 \\
8.9 \\
12.5\end{array}$ & $\begin{array}{r}14.5 \\
13.8 \\
3.8 \\
2.9 \\
4.2 \\
8.6 \\
16.2\end{array}$ & $\begin{array}{r}14.5 \\
13.2 \\
4.2 \\
2.4 \\
3.8 \\
8.8 \\
17.7\end{array}$ & $\begin{array}{r}14.3 \\
13.7 \\
3.3 \\
2.8 \\
3.8 \\
9.2 \\
15.4\end{array}$ & $\begin{array}{r}14.4 \\
13.6 \\
3.3 \\
2.9 \\
3.6 \\
8.6 \\
13.8\end{array}$ & $\begin{array}{r}14.6 \\
13.5 \\
3.5 \\
3.0 \\
3.4 \\
9.3 \\
12.5\end{array}$ \\
\hline $\begin{array}{l}\text { Hole } \\
D_{2}\end{array}$ & & & & & & & & & \\
\hline $\begin{array}{r}213.0 \\
182.5 \\
152.0 \\
121.5 \\
91.0 \\
60.5 \\
30.0\end{array}$ & $\begin{array}{r}15.2 \\
13.6 \\
3.5 \\
2.7 \\
3.8 \\
9.9 \\
15.1\end{array}$ & $\begin{array}{r}15.4 \\
13.8 \\
3.4 \\
2.8 \\
3.8 \\
10.0 \\
14.1\end{array}$ & $\begin{array}{r}14.5 \\
13.0 \\
3.2 \\
2.7 \\
4.0 \\
10.2 \\
12.6\end{array}$ & $\begin{array}{r}15.2 \\
13.5 \\
3.3 \\
2.9 \\
3.9 \\
9.7 \\
12.3\end{array}$ & $\begin{array}{r}15.1 \\
14.4 \\
3.4 \\
2.4 \\
4.1 \\
9.8 \\
14.3\end{array}$ & $\begin{array}{r}14.2 \\
13.2 \\
3.6 \\
2.7 \\
3.8 \\
9.9 \\
14.5\end{array}$ & $\begin{array}{r}14.2 \\
12.6 \\
3.3 \\
2.4 \\
3.9 \\
9.4 \\
12.4\end{array}$ & $\begin{array}{r}14.7 \\
13.4 \\
3.2 \\
2.6 \\
3.5 \\
9.2 \\
12.0\end{array}$ & $\begin{array}{r}15.8 \\
13.7 \\
2.9 \\
2.9 \\
4.0 \\
9.4 \\
10.8\end{array}$ \\
\hline
\end{tabular}


Table D-II (cont)

\begin{tabular}{|c|c|c|c|c|c|c|c|}
\hline $\begin{array}{l}\text { Distance } \\
\text { From }\end{array}$ & & $192-g$ & Additi & on $9 / 17$ & $\begin{array}{l}\text { Jate and } \\
82\end{array}$ & Time & \\
\hline Surrace & $9 / 10 / 82$ & $9 / 17 / 82$ & $9 / 17 / 82$ & $9 / 17 / 82$ & $9 / 17 / 82$ & $9 / 20 / 82$ & $9 / 20 / 82$ \\
\hline$(\mathrm{cm})$ & $10: 15$ & $10: 00$ & $14: 20$ & $14: 50$ & $15: 30$ & $9: 30$ & $14: 40$ \\
\hline $\begin{array}{l}\text { Hole } \\
D_{1}\end{array}$ & & - & & & & & \\
\hline $\begin{array}{r}213.0 \\
182.5 \\
152.0 \\
121.5 \\
91.0 \\
60.5 \\
30.0\end{array}$ & $\begin{array}{r}14.6 \\
13.5 \\
3.6 \\
3.0 \\
3.4 \\
9.3 \\
12.5\end{array}$ & $\begin{array}{r}14.6 \\
13.8 \\
3.5 \\
2.5 \\
4.2 \\
8.8 \\
11.5\end{array}$ & $\begin{array}{r}13.8 \\
19.5 \\
4.9 \\
2.0 \\
2.6 \\
32.6 \\
42.2\end{array}$ & $\begin{array}{r}14.3 \\
24.5 \\
4.7 \\
2.9 \\
7.2 \\
32.9 \\
42.7\end{array}$ & $\begin{array}{r}13.9 \\
25.1 \\
4.9 \\
2.8 \\
7.1 \\
29.8 \\
42.3\end{array}$ & $\begin{array}{r}18.5 \\
19.9 \\
4.5 \\
3.2 \\
6.1 \\
27.6 \\
36.8\end{array}$ & $\begin{array}{r}17.9 \\
20.2 \\
4.6 \\
3.3 \\
5.7 \\
29.0 \\
35.6\end{array}$ \\
\hline $\begin{array}{l}\text { Hole } \\
\mathrm{D}_{2}\end{array}$ & & & & & & & \\
\hline $\begin{array}{r}213.0 \\
182.5 \\
152.0 \\
121.5 \\
91.0 \\
60.5 \\
30.0\end{array}$ & $\begin{array}{r}15.8 \\
13.7 \\
2.9 \\
2.9 \\
4.0 \\
9.4 \\
10.8\end{array}$ & $\begin{array}{r}14.9 \\
13.4 \\
3.3 \\
2.7 \\
4.0 \\
8.9 \\
11.5\end{array}$ & $\begin{array}{r}14.9 \\
21.7 \\
3.8 \\
2.7 \\
4.3 \\
21.4 \\
41.6\end{array}$ & $\begin{array}{r}14.8 \\
22.4 \\
4.1 \\
3.1 \\
4.5 \\
22.3 \\
38.0\end{array}$ & $\begin{array}{r}14.1 \\
23.1 \\
4.9 \\
2.8 \\
4.7 \\
23.0 \\
38.9\end{array}$ & $\begin{array}{r}18.9 \\
19.6 \\
3.9 \\
3.1 \\
4.5 \\
25.6 \\
33.0\end{array}$ & $\begin{array}{r}18.5 \\
19.7 \\
3.6 \\
2.9 \\
5.0 \\
25.1 \\
32.5\end{array}$ \\
\hline
\end{tabular}


Table D-II (cont)

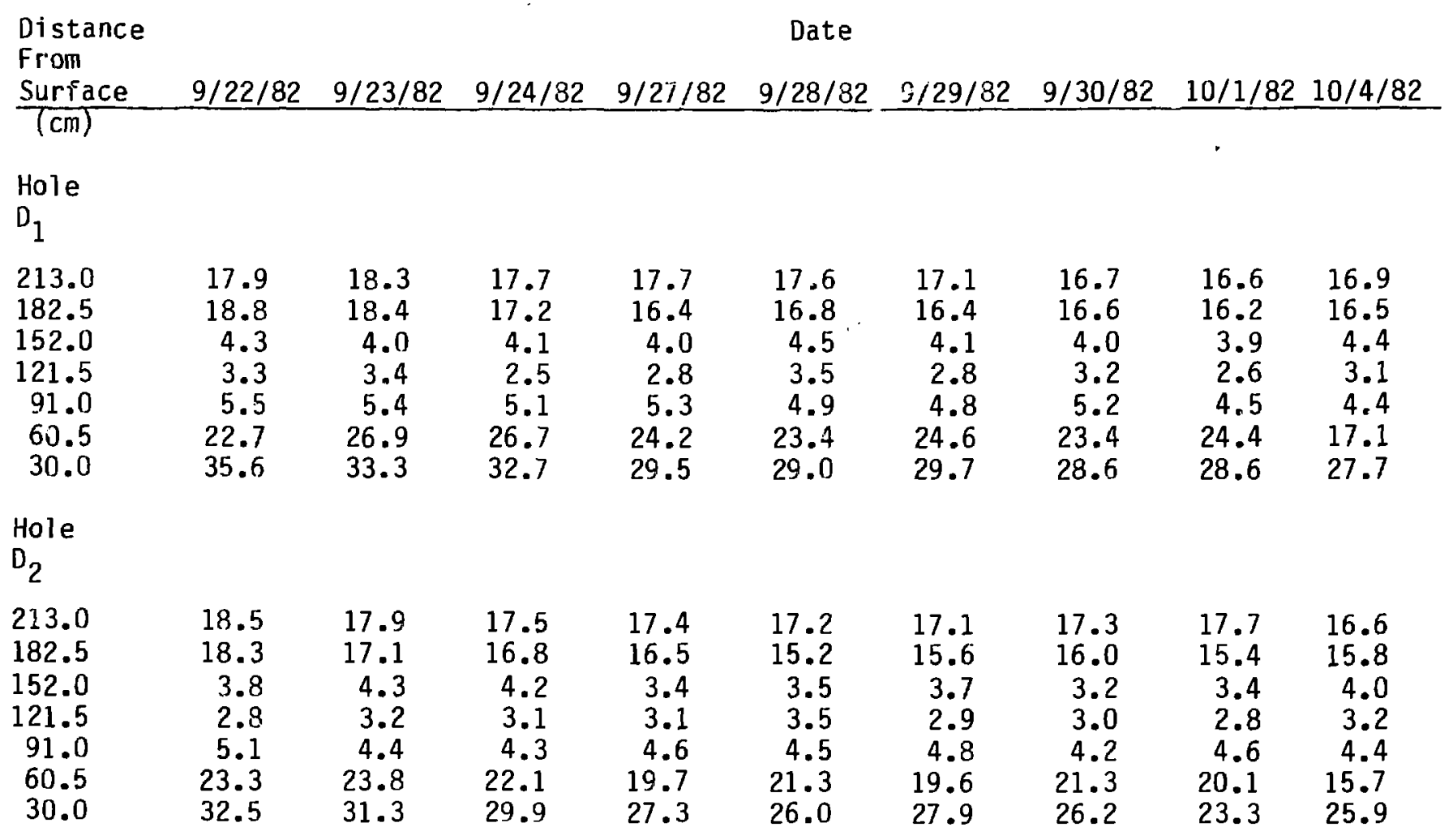


Table D-II (cont)

Distance* Date

From

Date

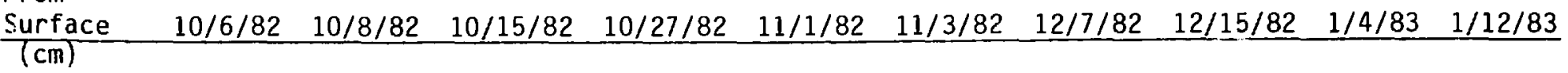

Hole

$\mathrm{D}_{1}$

\begin{tabular}{|c|c|c|c|c|c|c|c|c|c|c|}
\hline $\begin{array}{r}213.0 \\
182.5 \\
152.0 \\
121.5 \\
91.0 \\
60.5 \\
30.0\end{array}$ & $\begin{array}{r}16.1 \\
15.4 \\
3.7 \\
2.6 \\
4.5 \\
20.0 \\
25.5\end{array}$ & $\begin{array}{r}16.3 \\
14.7 \\
4.0 \\
2.0 \\
4.7 \\
19.4 \\
24.8\end{array}$ & $\begin{array}{r}16.3 \\
15.2 \\
4.3 \\
2.8 \\
4.2 \\
15.4 \\
24.9\end{array}$ & $\begin{array}{r}15.3 \\
14.5 \\
3.5 \\
3.1 \\
4.5 \\
16.4 \\
21.8\end{array}$ & $\begin{array}{r}15.7 \\
14.0 \\
3.9 \\
3.0 \\
4.5 \\
14.0 \\
20.8\end{array}$ & $\begin{array}{r}15.2 \\
14.1 \\
3.9 \\
2.9 \\
4.8 \\
14.8 \\
20.7\end{array}$ & $\begin{array}{r}16.1 \\
14.1 \\
3.5 \\
3.6 \\
5.2 \\
13.3 \\
26.4\end{array}$ & $\begin{array}{r}13.9 \\
13.4 \\
4.9 \\
2.2 \\
4.2 \\
14.3 \\
24.9\end{array}$ & $\begin{array}{r}14.4 \\
13.6 \\
4.0 \\
2.5 \\
3.7 \\
15.3 \\
24.7\end{array}$ & $\begin{array}{r}14.8 \\
13.2 \\
3.7 \\
2.6 \\
4.1 \\
17.8 \\
27.5\end{array}$ \\
\hline
\end{tabular}

Hole

$\mathrm{D}_{2}$

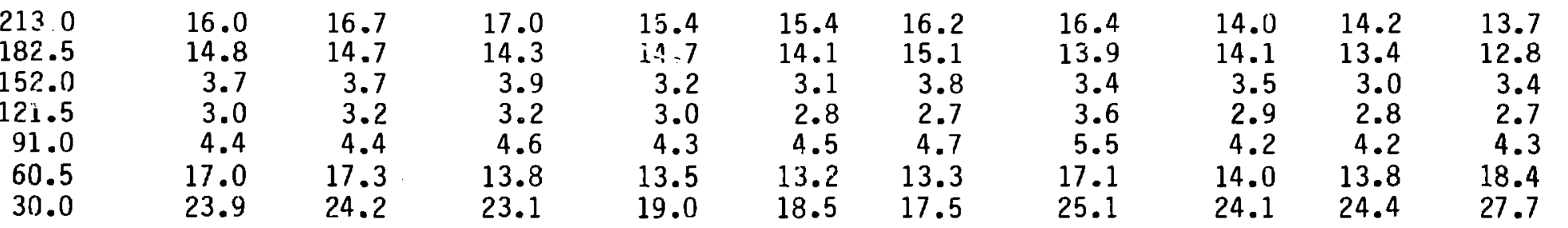


Table D-II (cont)

\begin{tabular}{lrrrrr}
$\begin{array}{l}\text { Distance } \\
\text { From } \\
\text { Surface }\end{array}$ & $1 / 25 / 83$ & $2 / 9 / 83$ & $2 / 22 / 83$ & $3 / 7 / 33$ & $3 / 14 / 83$ \\
\hline (cm) & & & & \\
& & & & \\
Hole & & & & & \\
$D_{1}$ & & & & & \\
213.0 & 14.2 & 13.8 & 14.7 & 16.8 & 16.6 \\
182.5 & 13.7 & 13.5 & 15.1 & 16.2 & 16.2 \\
152.0 & 4.3 & 4.5 & 4.1 & 4.4 & 4.1 \\
121.5 & 2.5 & 2.8 & 2.5 & 2.8 & 3.2 \\
91.0 & 4.0 & 4.3 & 5.0 & 5.7 & 5.6 \\
60.5 & 16.2 & 15.3 & 22.2 & 24.6 & 21.7 \\
30.0 & 28.5 & 28.3 & 36.8 & 34.2 & 33.0 \\
& & & & & \\
Hole & & & & & \\
$D_{2}$ & & & & & \\
213.0 & 13.7 & 14.1 & 17.7 & 16.8 & 16.8 \\
182.5 & 13.1 & 13.0 & 21.6 & 15.7 & 16.4 \\
152.0 & 3.1 & 3.2 & 4.1 & 3.6 & 3.8 \\
121.5 & 2.6 & 2.5 & 3.6 & 3.1 & 4.0 \\
91.0 & 3.9 & 4.1 & 6.6 & 5.5 & 4.8 \\
60.5 & 16.8 & 15.0 & 25.9 & 25.0 & 21.7 \\
30.0 & 27.0 & 25.7 & 35.3 & 34.6 & 31.5 \\
& & & & &
\end{tabular}


Table D-III: Moisture Measured at End of Horizontal Access Tube

for First Field Season ( $\%$ Moisture by Volume)

Caisson $C$ and $D$

\begin{tabular}{|c|c|c|c|c|c|c|c|c|c|c|c|}
\hline $\begin{array}{l}\text { Distance } \\
\text { From } \\
\text { Surface }\end{array}$ & $8 / 19 / 82$ & $8 / 25 / 82$ & $9 / 7 / 82$ & $9 / 10 / 82$ & $\begin{array}{r}\text { Addi } \\
9 / 17 / 82 \\
\end{array}$ & $\begin{array}{r}\text { Date } \\
\text { ion of } 1 \\
9 / 20 / 82 \\
\end{array}$ & $\begin{array}{c}2 \text { gallons } \\
9 / 20 / 82 \\
\end{array}$ & $\begin{array}{l}\text { of water } \\
9 / 22 / 82\end{array}$ & $9 / 23 / 82$ & $9 / 24 / 82$ & $9 / 27 / 82$ \\
\hline$(\mathrm{cm})$ & & & & & & $9: 20$ & $14: 20$ & & & & \\
\hline \multicolumn{12}{|l|}{$\begin{array}{c}\text { Caisson } \\
C\end{array}$} \\
\hline $\begin{array}{l}197 \\
271 \\
347 \\
422\end{array}$ & $\begin{array}{l}13.5 \\
14.3 \\
13.1 \\
13.9\end{array}$ & $\begin{array}{l}13.8 \\
14.5 \\
13.3 \\
14.3\end{array}$ & $\begin{array}{l}13.1 \\
13.9 \\
12.8 \\
14.1\end{array}$ & $\begin{array}{l}13.7 \\
13.7 \\
13.2 \\
14.0\end{array}$ & $\begin{array}{l}13.4 \\
13.9 \\
13.0 \\
14.1\end{array}$ & $\begin{array}{l}13.4 \\
13.7 \\
13.0 \\
14.2\end{array}$ & $\begin{array}{l}13.4 \\
14.0 \\
13.2 \\
14.0\end{array}$ & $\begin{array}{l}13.4 \\
13.8 \\
12.8 \\
13.9\end{array}$ & $\begin{array}{l}13.4 \\
13.7 \\
13.4 \\
13.6\end{array}$ & $\begin{array}{l}14.0 \\
14.0 \\
12.4 \\
12.8\end{array}$ & $\begin{array}{l}13.8 \\
14.0 \\
13.0 \\
14.1\end{array}$ \\
\hline $\begin{array}{c}\text { Caisson } \\
\text { D }\end{array}$ & $\therefore$ & & & & & & & & & & \\
\hline $\begin{array}{l}197 \\
271 \\
347 \\
422\end{array}$ & $\begin{array}{l}13.3 \\
14.9 \\
16.5 \\
14.7\end{array}$ & $\begin{array}{l}13.6 \\
14.7 \\
16.9 \\
15.3\end{array}$ & $\begin{array}{l}12.9 \\
13.8 \\
16.4 \\
14.7\end{array}$ & $\begin{array}{l}14.2 \\
14.1 \\
15.5 \\
14.1\end{array}$ & $\begin{array}{l}13.0 \\
14.1 \\
16.5 \\
15.3\end{array}$ & $\begin{array}{l}18.3 \\
14.4 \\
17.0 \\
14.6\end{array}$ & $\begin{array}{l}18.1 \\
14.2 \\
16.3 \\
14.8\end{array}$ & $\begin{array}{l}17.8 \\
15.3 \\
16.3 \\
15.2\end{array}$ & $\begin{array}{l}17.4 \\
15.5 \\
16.6 \\
15.0\end{array}$ & $\begin{array}{l}17.2 \\
15.0 \\
16.7 \\
14.6\end{array}$ & $\begin{array}{l}16.6 \\
17.1 \\
16.7 \\
15.1\end{array}$ \\
\hline
\end{tabular}


Table D-III (cont)

\begin{tabular}{|c|c|c|c|c|c|c|c|c|c|c|c|}
\hline \multirow{2}{*}{$\begin{array}{l}\text { Distance } \\
\text { From } \\
\text { Surface } \\
\text { (cm) }\end{array}$} & \multirow[b]{2}{*}{$9 / 27 / 82$} & \multirow[b]{2}{*}{$9 / 28 / 82$} & \multicolumn{8}{|c|}{ Date } & \multirow[b]{2}{*}{$12 / 15 / 82$} \\
\hline & & & $9 / 29 / 82$ & $9 / 30 / 82$ & $10 / 1 / 82$ & $10 / 4 / 82$ & $10 / 6 / 82$ & $10 / 8 / 82$ & $10 / 15 / 82$ & $11 / 1 / 82$ & \\
\hline \multicolumn{12}{|l|}{$\begin{array}{c}\text { Caisson } \\
\text { C }\end{array}$} \\
\hline $\begin{array}{l}197 \\
271 \\
347 \\
422\end{array}$ & $\begin{array}{l}13.8 \\
14.0 \\
13.0 \\
14.1\end{array}$ & $\begin{array}{l}14.1 \\
13.7 \\
12.5 \\
13.6\end{array}$ & $\begin{array}{l}13.8 \\
13.7 \\
13.2 \\
13.5\end{array}$ & $\begin{array}{l}14.3 \\
14.3 \\
12.3 \\
13.6\end{array}$ & $\begin{array}{l}14.2 \\
13.8 \\
12.7 \\
13.8\end{array}$ & $\begin{array}{l}14.3 \\
14.5 \\
12.7 \\
13.6\end{array}$ & $\begin{array}{l}14.3 \\
14.4 \\
12.6 \\
13.8\end{array}$ & $\begin{array}{l}14.1 \\
14.5 \\
13.3 \\
13.6\end{array}$ & $\begin{array}{l}14.5 \\
15.0 \\
13.3 \\
14.2\end{array}$ & $\begin{array}{l}14.0 \\
15.0 \\
13.0 \\
13.6\end{array}$ & $\begin{array}{l}13.4 \\
13.6 \\
13.3 \\
14.7\end{array}$ \\
\hline \multicolumn{12}{|l|}{$\begin{array}{c}\text { Caisson } \\
D\end{array}$} \\
\hline $\begin{array}{l}197 \\
271 \\
347 \\
422\end{array}$ & $\begin{array}{l}16.6 \\
17.1 \\
16.7 \\
15.1\end{array}$ & $\begin{array}{l}16.0 \\
16.3 \\
16.7 \\
14.8\end{array}$ & $\begin{array}{l}15.9 \\
16.5 \\
17.3 \\
15.1\end{array}$ & $\begin{array}{l}16.0 \\
16.4 \\
17.2 \\
15.0\end{array}$ & $\begin{array}{l}16.0 \\
16.8 \\
17.4 \\
14.9\end{array}$ & $\begin{array}{l}15.7 \\
16.5 \\
17.6 \\
15.2\end{array}$ & $\begin{array}{l}15.3 \\
16.2 \\
16.9 \\
14.8\end{array}$ & $\begin{array}{l}15.0 \\
16.4 \\
17.2 \\
15.2\end{array}$ & $\begin{array}{l}14.7 \\
16.2 \\
17.8 \\
15.7\end{array}$ & $\begin{array}{l}14.3 \\
15.2 \\
17.3 \\
15.4\end{array}$ & $\begin{array}{l}13.4 \\
14.6 \\
10.6 \\
15.8\end{array}$ \\
\hline
\end{tabular}




\begin{tabular}{|c|c|c|c|c|c|c|c|c|c|c|c|}
\hline $\begin{array}{l}\text { Distance } \\
\text { From } \\
\text { Caisson } \\
\text { Center }\end{array}$ & $11 / 9 / 82$ & $12 / 6 / 82$ & $1 / 12 / 83$ & $1 / 18 / 83$ & $2 / 2 / 83$ & $2 / 7 / 83$ & $2 / 17 / 83$ & $2 / 25 / 83$ & $3 / 7 / 83$ & $3 / 14 / 83$ & $3 / 31 / 83$ \\
\hline$(\mathrm{in})$ & & & & & & & & & & & \\
\hline $\begin{array}{r}0 \\
3 \\
5 \\
9 \\
12 \\
15 \\
18 \\
21 \\
24 \\
27 \\
30 \\
33 \\
36 \\
39 \\
42\end{array}$ & $\begin{array}{l}16.6 \\
16.7 \\
16.5 \\
16.6 \\
16.5 \\
16.7 \\
16.8 \\
17.1 \\
17.3 \\
17.4 \\
17.4 \\
17.3 \\
17.5 \\
17.4 \\
17.3\end{array}$ & $\begin{array}{l}16.2 \\
16.0 \\
16.2 \\
16.0 \\
16.2 \\
16.5 \\
16.4 \\
16.5 \\
16.4 \\
16.7 \\
16.9 \\
17.0 \\
16.9 \\
16.6 \\
16.7\end{array}$ & $\begin{array}{l}15.9 \\
16.0 \\
15.8 \\
16.0 \\
15.5 \\
16.0 \\
16.1 \\
16.1 \\
16.1 \\
16.5 \\
16.5 \\
16.5 \\
16.4 \\
16.4 \\
16.0\end{array}$ & $\begin{array}{l}15.9 \\
16.2 \\
16.0 \\
16.0 \\
16.0 \\
16.0 \\
15.9 \\
16.3 \\
16.4 \\
16.6 \\
16.6 \\
16.8 \\
16.5 \\
16.7 \\
16.4\end{array}$ & $\begin{array}{l}16.2 \\
15.9 \\
15.7 \\
16.0 \\
16.0 \\
16.3 \\
16.4 \\
16.5 \\
16.5 \\
16.6 \\
16.5 \\
16.7 \\
16.5 \\
16.6 \\
16.5\end{array}$ & $\begin{array}{l}16.0 \\
16.1 \\
15.9 \\
16.2 \\
15.9 \\
16.1 \\
16.3 \\
16.5 \\
16.7 \\
17.0 \\
16.6 \\
16.9 \\
16.9 \\
16.9 \\
16.3\end{array}$ & $\begin{array}{l}16.0 \\
16.3 \\
16.1 \\
16.1 \\
16.0 \\
16.2 \\
16.6 \\
16.5 \\
17.0 \\
16.6 \\
16.6 \\
16.9 \\
17.0 \\
16.6 \\
16.9\end{array}$ & $\begin{array}{l}16.4 \\
16.4 \\
16.2 \\
16.1 \\
16.3 \\
16.6 \\
17.0 \\
17.0 \\
17.4 \\
17.6 \\
17.7 \\
17.8 \\
17.7 \\
17.8 \\
17.4\end{array}$ & $\begin{array}{l}17.3 \\
17.2 \\
17.5 \\
17.4 \\
17.8 \\
18.1 \\
18.0 \\
18.4 \\
18.8 \\
18.9 \\
19.5 \\
19.5 \\
19.9 \\
19.8 \\
19.5\end{array}$ & $\begin{array}{l}17.5 \\
18.1 \\
18.0 \\
17.8 \\
18.0 \\
18.7 \\
18.8 \\
19.1 \\
19.4 \\
19.4 \\
19.7 \\
20.1 \\
19.9 \\
20.0 \\
19.8\end{array}$ & $\begin{array}{l}17.7 \\
17.9 \\
17.9 \\
18.0 \\
18.0 \\
18.4 \\
18.5 \\
18.7 \\
19.2 \\
19.1 \\
19.3 \\
19.3 \\
19.5 \\
19.4 \\
19.3\end{array}$ \\
\hline
\end{tabular}

\#The data are given as raw data. In order to obtain per cent moisture by volume, the data should be multiplied by .85 
Table D-IV: Horizontal Profiles for Caisson C for First Field Season

(271 cm From Surface) (Relative Moisture)

Distance Date

From

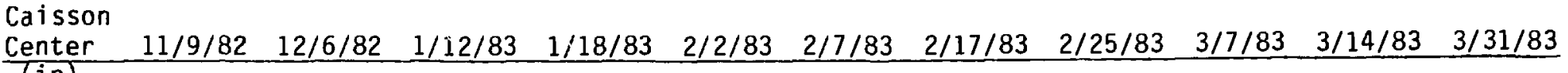

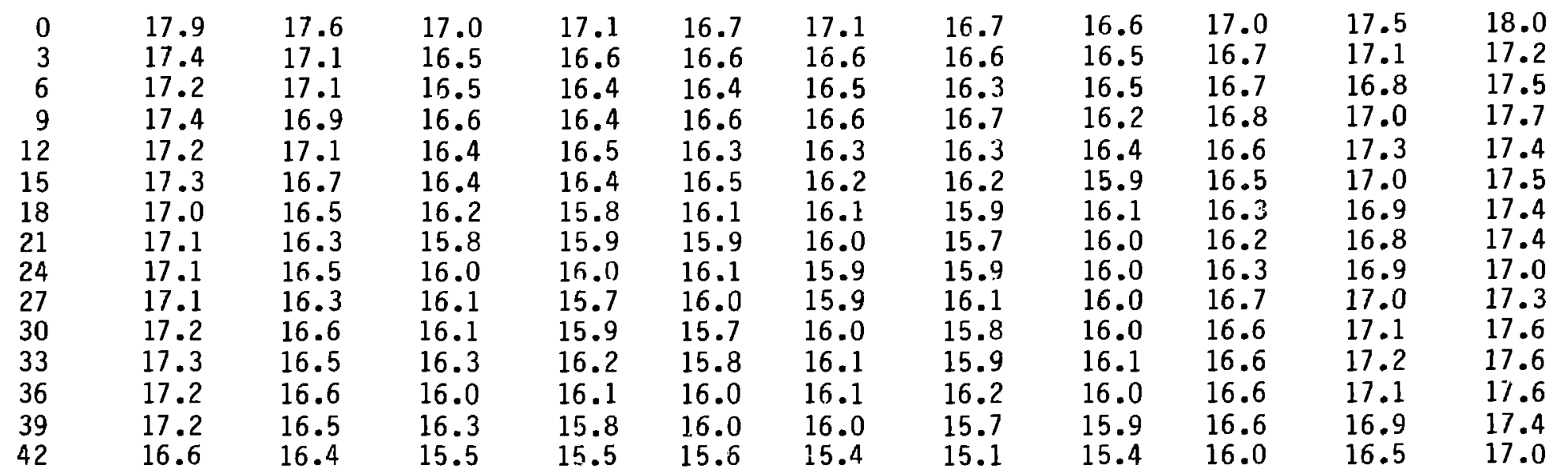




\begin{tabular}{|c|c|c|c|c|c|c|c|c|c|c|c|}
\hline $\begin{array}{l}\text { Distance } \\
\text { From } \\
\text { Caisson } \\
\text { Center } \\
\end{array}$ & $11 / 9 / 82$ & $12 / 6 / 82$ & $1 / 12 / 83$ & $1 / 18 / 83$ & $2 / 2 / 83$ & $2 / 7 / 83$ & $2 / 17 / 83$ & $2 / 25 / 83$ & $3 / 7 / 83$ & $3 / 14 / 83$ & $3 / 31 / 83$ \\
\hline $\begin{array}{r}0 \\
3 \\
6 \\
9 \\
12 \\
15 \\
18 \\
21 \\
24 \\
27 \\
30 \\
33 \\
36 \\
39 \\
42\end{array}$ & $\begin{array}{l}16.4 \\
15.8 \\
15.5 \\
15.5 \\
15.7 \\
15.8 \\
15.9 \\
16.3 \\
16.2 \\
16.6 \\
16.4 \\
16.3 \\
15.9 \\
16.1 \\
15.8\end{array}$ & $\begin{array}{l}16.3 \\
15.8 \\
15.6 \\
15.5 \\
15.4 \\
15.7 \\
15.7 \\
16.0 \\
16.3 \\
16.4 \\
16.5 \\
16.4 \\
16.1 \\
16.2 \\
15.5\end{array}$ & $\begin{array}{l}15.9 \\
15.3 \\
15.2 \\
15.2 \\
15.3 \\
15.3 \\
15.6 \\
15.8 \\
15.9 \\
16.0 \\
16.0 \\
15.9 \\
15.9 \\
15.6 \\
15.5\end{array}$ & $\begin{array}{l}16.0 \\
15.3 \\
15.2 \\
15.2 \\
15.4 \\
15.5 \\
15.6 \\
15.8 \\
16.2 \\
16.3 \\
16.1 \\
15.8 \\
15.8 \\
15.6 \\
15.5\end{array}$ & $\begin{array}{l}16.0 \\
15.4 \\
15.5 \\
15.3 \\
15.4 \\
15.6 \\
15.6 \\
15.7 \\
16.0 \\
16.2 \\
16.1 \\
16.1 \\
15.8 \\
15.6 \\
15.2\end{array}$ & $\begin{array}{l}16.3 \\
15.6 \\
15.4 \\
15.3 \\
15.4 \\
15.6 \\
15.5 \\
15.7 \\
15.9 \\
16.2 \\
15.9 \\
15.8 \\
15.9 \\
15.4 \\
15.3\end{array}$ & $\begin{array}{l}15.9 \\
15.3 \\
15.3 \\
15.2 \\
15.4 \\
15.2 \\
15.5 \\
15.8 \\
15.8 \\
15.9 \\
16.1 \\
16.0 \\
15.6 \\
15.4 \\
15.2\end{array}$ & $\begin{array}{l}15.8 \\
15.3 \\
15.2 \\
15.2 \\
15.3 \\
15.5 \\
15.5 \\
15.8 \\
15.7 \\
16.0 \\
16.0 \\
15.7 \\
15.4 \\
15.3 \\
15.4\end{array}$ & $\begin{array}{l}15.7 \\
15.5 \\
15.2 \\
15.2 \\
15.4 \\
15.3 \\
15.5 \\
15.7 \\
15.8 \\
16.1 \\
16.0 \\
15.9 \\
15.6 \\
15.6 \\
15.1\end{array}$ & $\begin{array}{l}15.7 \\
15.4 \\
15.3 \\
15.2 \\
15.3 \\
15.3 \\
15.6 \\
15.8 \\
16.0 \\
16.0 \\
15.9 \\
15.5 \\
15.6 \\
15.3 \\
15.3\end{array}$ & $\begin{array}{l}15.5 \\
15.2 \\
14.9 \\
15.0 \\
15.0 \\
15.5 \\
15.5 \\
15.9 \\
15.9 \\
16.0 \\
16.0 \\
16.0 \\
15.8 \\
16.0 \\
15.4\end{array}$ \\
\hline
\end{tabular}


Table D-IV: Horizontal Profiles for Caisson C for First Field Season

(422. cm From Surface) (Relative Moisture)

\begin{tabular}{|c|c|c|c|c|c|c|c|c|c|c|c|}
\hline $\begin{array}{l}\text { Distance } \\
\text { From } \\
\text { Caisson } \\
\text { Center }\end{array}$ & $11 / 9 / 82$ & $12 / 6 / 82$ & $1 / 12 / 83$ & $1 / 18 / 83$ & $2 / 2 / 83$ & $2 / 7 / 83$ & $2 / 17 / 83$ & $2 / 25 / 83$ & $3 / 7 / 83$ & $3 / 14 / 83$ & $3 / 31 / 83$ \\
\hline$(\mathrm{in})$ & & & & & & & & & & & \\
\hline $\begin{array}{r}0 \\
3 \\
6 \\
9 \\
12 \\
15 \\
18 \\
21 \\
24 \\
27 \\
30 \\
33 \\
36 \\
39 \\
42\end{array}$ & $\begin{array}{l}17.3 \\
16.6 \\
16.5 \\
17.2 \\
17.3 \\
17.4 \\
17.4 \\
17.5 \\
17.2 \\
17.0 \\
16.7 \\
16.8 \\
16.8 \\
16.5 \\
16.1\end{array}$ & $\begin{array}{l}17.1 \\
16.8 \\
17.1 \\
17.2 \\
17.5 \\
17.4 \\
17.6 \\
17.5 \\
17.4 \\
17.2 \\
17.0 \\
16.9 \\
16.6 \\
16.6 \\
16.4\end{array}$ & $\begin{array}{l}16.9 \\
16.6 \\
16.6 \\
17.2 \\
17.3 \\
17.6 \\
17.5 \\
17.2 \\
17.0 \\
17.0 \\
16.8 \\
16.8 \\
16.7 \\
16.3 \\
16.1\end{array}$ & $\begin{array}{l}17.1 \\
16.8 \\
16.9 \\
17.2 \\
17.5 \\
17.6 \\
17.6 \\
17.5 \\
17.2 \\
17.3 \\
17.0 \\
16.9 \\
16.7 \\
16.7 \\
16.0\end{array}$ & $\begin{array}{l}17.1 \\
16.8 \\
16.8 \\
17.0 \\
17.5 \\
17.5 \\
17.6 \\
17.5 \\
17.4 \\
17.1 \\
16.9 \\
16.9 \\
16.4 \\
16.5 \\
16.1\end{array}$ & $\begin{array}{l}17.1 \\
16.5 \\
16.8 \\
17.1 \\
17.6 \\
17.7 \\
17.6 \\
17.5 \\
17.5 \\
17.1 \\
17.3 \\
16.7 \\
16.9 \\
16.5 \\
16.2\end{array}$ & $\begin{array}{l}17.5 \\
16.8 \\
16.9 \\
17.4 \\
17.4 \\
17.4 \\
17.4 \\
17.5 \\
17.3 \\
17.1 \\
16.8 \\
16.8 \\
16.5 \\
16.3 \\
16.1\end{array}$ & $\begin{array}{l}17.1 \\
16.7 \\
16.9 \\
17.2 \\
17.2 \\
17.6 \\
17.5 \\
17.6 \\
17.5 \\
16.9 \\
16.9 \\
16.8 \\
16.6 \\
16.5 \\
15.8\end{array}$ & $\begin{array}{l}16.9 \\
16.7 \\
16.9 \\
16.8 \\
16.8 \\
17.6 \\
17.4 \\
17.3 \\
17.4 \\
17.0 \\
17.1 \\
16.6 \\
16.4 \\
16.6 \\
16.0\end{array}$ & $\begin{array}{l}17.0 \\
16.6 \\
16.8 \\
17.2 \\
17.2 \\
17.6 \\
17.6 \\
17.4 \\
17.0 \\
17.0 \\
16.9 \\
16.6 \\
16.6 \\
16.6 \\
16.3\end{array}$ & $\begin{array}{l}16.6 \\
16.3 \\
16.3 \\
16.9 \\
16.9 \\
17.1 \\
17.2 \\
17.0 \\
16.7 \\
16.7 \\
16.5 \\
16.3 \\
16.3 \\
16.0 \\
15.9\end{array}$ \\
\hline
\end{tabular}


Table D-V: Horizontal Profiles for Caisson D for First Field Season (422 cm From Surface) (Relative Moisture)

\begin{tabular}{|c|c|c|c|c|c|c|c|c|c|c|c|c|}
\hline $\begin{array}{l}\text { Distance } \\
\text { From } \\
\text { Caisson } \\
\text { Center }\end{array}$ & $11 / 9 / 82$ & $12 / 6 / 82$ & $1 / 12 / 83$ & $1 / 18 / 83$ & $2 / 2 / 83$ & $2 / 7 / 83$ & $2 / 17 / 83$ & $2 / 25 / 83$ & $3 / 7 / 83$ & $3 / 14 / 83$ & $3 / 31 / 83$ & $3 / 31 / 83$ \\
\hline$(i n)$ & & & & & & & & & & & & \\
\hline $\begin{array}{r}0 \\
3 \\
6 \\
9 \\
12 \\
15 \\
18 \\
21 \\
24 \\
27 \\
30 \\
33 \\
36 \\
39 \\
42\end{array}$ & $\begin{array}{l}18.8 \\
18.1 \\
18.2 \\
18.1 \\
18.1 \\
17.8 \\
17.4 \\
17.2 \\
17.3 \\
17.0 \\
17.2 \\
17.2 \\
17.4 \\
17.3 \\
16.4\end{array}$ & $\begin{array}{l}18.6 \\
17.6 \\
18.1 \\
17.7 \\
17.9 \\
17.2 \\
17.5 \\
17.4 \\
17.1 \\
17.0 \\
17.0 \\
17.1 \\
17.2 \\
16.9 \\
16.1\end{array}$ & $\begin{array}{l}18.3 \\
17.8 \\
17.7 \\
17.6 \\
17.3 \\
17.1 \\
17.2 \\
16.8 \\
16.6 \\
16.5 \\
10.7 \\
16.9 \\
16.7 \\
16.6 \\
16.1\end{array}$ & $\begin{array}{l}18.6 \\
18.0 \\
17.4 \\
17.6 \\
17.6 \\
17.3 \\
17.2 \\
16.9 \\
16.8 \\
16.7 \\
16.7 \\
16.9 \\
16.8 \\
16.6 \\
16.5\end{array}$ & $\begin{array}{l}18.4 \\
17.7 \\
17.7 \\
18.2 \\
17.7 \\
17.7 \\
17.0 \\
16.8 \\
17.6 \\
17.1 \\
17.0 \\
17.0 \\
16.6 \\
16.5 \\
15.9\end{array}$ & $\begin{array}{l}18.4 \\
17.6 \\
17.7 \\
17.7 \\
17.7 \\
17.6 \\
17.5 \\
16.8 \\
16.7 \\
16.7 \\
16.8 \\
16.9 \\
16.8 \\
16.7 \\
16.1\end{array}$ & $\begin{array}{l}18.4 \\
18.0 \\
17.5 \\
17.4 \\
17.5 \\
17.2 \\
17.0 \\
16.8 \\
16.6 \\
16.7 \\
16.9 \\
16.7 \\
17.1 \\
16.5 \\
16.0\end{array}$ & $\begin{array}{l}18.3 \\
17.6 \\
17.7 \\
17.6 \\
17.6 \\
17.4 \\
17.0 \\
16.9 \\
16.5 \\
16.9 \\
16.8 \\
16.9 \\
16.7 \\
16.7 \\
16.2\end{array}$ & $\begin{array}{l}18.1 \\
17.5 \\
17.7 \\
17.7 \\
17.5 \\
17.4 \\
17.0 \\
16.7 \\
16.9 \\
16.9 \\
16.8 \\
17.0 \\
17.0 \\
16.7 \\
16.1\end{array}$ & $\begin{array}{l}18.4 \\
18.0 \\
17.8 \\
17.7 \\
17.7 \\
17.4 \\
17.1 \\
17.0 \\
16.9 \\
17.0 \\
16.8 \\
16.9 \\
16.9 \\
16.9 \\
16.3\end{array}$ & $\begin{array}{l}19.4 \\
18.4 \\
18.5 \\
18.4 \\
18.4 \\
17.4 \\
17.7 \\
17.5 \\
17.3 \\
17.2 \\
17.5 \\
17.8 \\
17.7 \\
17.6 \\
16.8\end{array}$ & $\begin{array}{l}18.8 \\
17.8 \\
17.9 \\
17.9 \\
17.9 \\
17.4 \\
17.2 \\
17.0 \\
16.8 \\
16.7 \\
17.0 \\
17.3 \\
17.2 \\
17.1 \\
16.3\end{array}$ \\
\hline
\end{tabular}


Table D-V: Horizontal Profiles for Caisson D for First Field Season

(197 cm From Surface) (Relative Moisture)*

Distance

Date

Frain

Caisson

Center

$\begin{array}{lllll}11 / 9 / 82 & 12 / 6 / 82 & 1 / 12 / 83 & 1 / 18 / 83 & 2 / 2 / 83\end{array}$

$2 / 7 / 83 \quad 2 / 17 / 83 \quad 2 / 25 / 83$

$3 / 7 / 83 \quad 3 / 14 / 83$

$3 / 31 / 83 \quad 3 / 31 / 83$

\begin{tabular}{|c|c|c|c|c|c|c|c|c|c|c|c|}
\hline $\begin{array}{l}16.5 \\
16.3 \\
16.0 \\
15.7 \\
15.8 \\
15.7 \\
16.0 \\
16.1 \\
16.7 \\
16.9 \\
17.4 \\
17.4 \\
17.5 \\
17.1 \\
16.4\end{array}$ & $\begin{array}{l}16.0 \\
15.3 \\
15.4 \\
14.9 \\
15.0 \\
15.1 \\
15.6 \\
15.6 \\
16.0 \\
16.5 \\
16.7 \\
16.8 \\
17.1 \\
16.3 \\
16.0\end{array}$ & $\begin{array}{l}15.5 \\
15.0 \\
14.8 \\
14.7 \\
14.7 \\
14.5 \\
14.7 \\
15.1 \\
15.8 \\
16.0 \\
16.4 \\
16.5 \\
16.3 \\
16.0 \\
15.6\end{array}$ & $\begin{array}{l}15.6 \\
14.8 \\
14.7 \\
14.7 \\
14.7 \\
15.0 \\
15.0 \\
15.4 \\
16.0 \\
16.0 \\
16.4 \\
16.5 \\
16.6 \\
16.0 \\
15.8\end{array}$ & $\begin{array}{l}15.4 \\
15.0 \\
14.8 \\
14.9 \\
14.9 \\
15.1 \\
15.4 \\
15.6 \\
16.1 \\
16.7 \\
16.9 \\
17.0 \\
17.1 \\
17.0 \\
16.7\end{array}$ & $\begin{array}{l}15.6 \\
15.1 \\
15.0 \\
14.9 \\
14.9 \\
15.4 \\
15.5 \\
15.9 \\
16.4 \\
16.6 \\
16.9 \\
17.4 \\
17.3 \\
16.9 \\
16.7\end{array}$ & $\begin{array}{l}15.7 \\
15.4 \\
15.3 \\
15.4 \\
15.7 \\
16.1 \\
16.5 \\
16.8 \\
17.4 \\
18.1 \\
18.4 \\
19.0 \\
19.0 \\
18.7 \\
18.6\end{array}$ & $\begin{array}{l}18.4 \\
18.3 \\
18.8 \\
19.7 \\
20.4 \\
21.6 \\
22.2 \\
22.5 \\
23.5 \\
23.6 \\
24.1 \\
24.5 \\
24.3 \\
24.1 \\
22.7\end{array}$ & $\begin{array}{l}19.8 \\
19.3 \\
19.8 \\
20.2 \\
21.0 \\
21.2 \\
21.3 \\
21.8 \\
22.3 \\
22.3 \\
23.0 \\
22.7 \\
22.8 \\
22.6 \\
21.9\end{array}$ & $\begin{array}{l}18.9 \\
18.7 \\
18.8 \\
19.5 \\
19.6 \\
20.1 \\
20.2 \\
20.4 \\
20.5 \\
20.8 \\
21.2 \\
21.5 \\
20.8 \\
20.9 \\
20.2\end{array}$ & $\begin{array}{l}20.5 \\
20.2 \\
20.6 \\
20.4 \\
20.5 \\
20.6 \\
20.8 \\
21.1 \\
21.4 \\
21.6 \\
21.3 \\
21.6 \\
21.6 \\
20.8 \\
20.3\end{array}$ & $\begin{array}{l}19.8 \\
19.6 \\
2 . .0 \\
19.8 \\
20.0 \\
20.0 \\
20.2 \\
20.5 \\
20.8 \\
21.0 \\
20.7 \\
20.9 \\
21.0 \\
20.2 \\
19.7\end{array}$ \\
\hline
\end{tabular}

*The data are given as raw data. To obtain per cent moisture by volume, the data should be multiplied by .85 . 
Table D-V: Ho-izontal Profiles for Caisson D for First Field Season

(271 cm From Surface) (Relative Moisture)

Distance

Date

From

Caisson

Center

$\begin{array}{llll}11 / 9 / 82 & 12 / 6 / 82 & 1 / 12 / 83 & 1 / 18 / 83\end{array}$

$2 / 2 / 83$

$2 / 7 / 83$

$2 / 17 / 83 \quad 2 / 25 / 83 \quad 3 / 7 / 83 \quad 3 / 14 / 83 \quad 3 / 3 ! / 83$

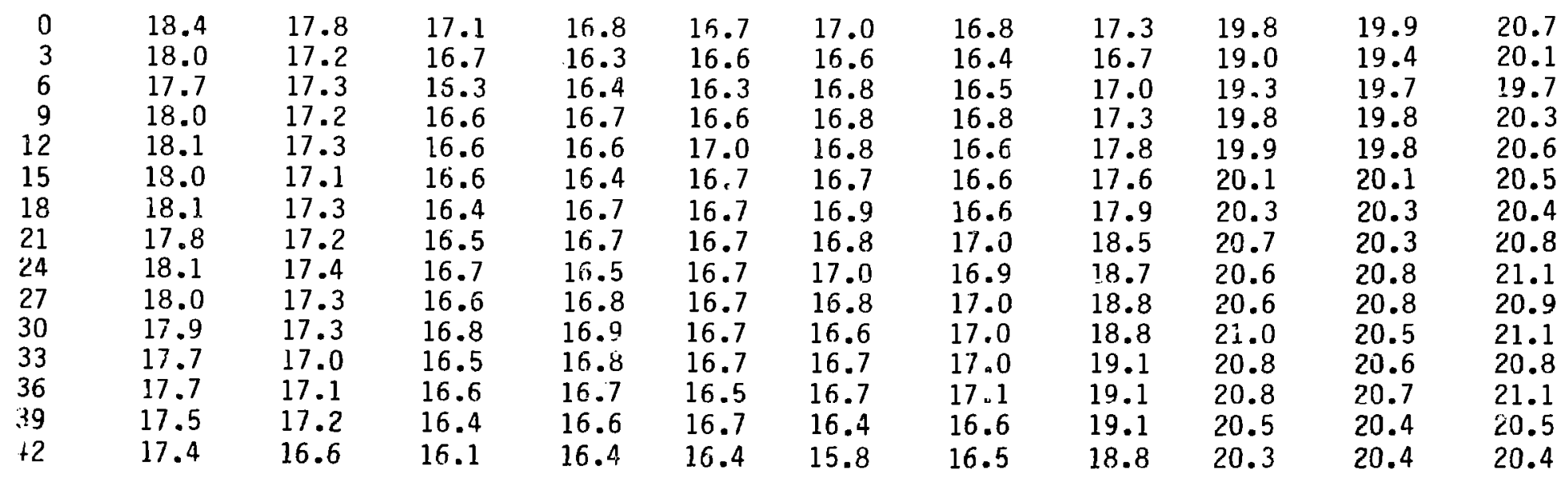


Table D-V: Horizontal Profiles for iaisson D for First Field Season ( $347 \mathrm{~cm}$ From Surface) (Relative Moisture)

\begin{tabular}{|c|c|c|c|c|c|c|c|c|c|c|c|c|}
\hline $\begin{array}{l}\text { Distance } \\
\text { From } \\
\text { Caisson } \\
\text { Center } \\
\end{array}$ & $11 / 9 / 82$ & $12 / 6 / 82$ & $1 / 12 / 83$ & $1 / 18 / 83$ & $2 / 2 / 83$ & $2 / 7 / 83$ & $2 / 17 / 83$ & $2 / 25 / 83$ & $3 / 7 / 83$ & $3 / 14 / 83$ & $3 / 31 / 83$ & $3 / 31 / 83$ \\
\hline$(\mathrm{in})$ & & & & & & & & & & & & \\
\hline $\begin{array}{r}0 \\
3 \\
6 \\
9 \\
12 \\
15 \\
18 \\
21 \\
24 \\
27 \\
30 \\
33 \\
36 \\
39 \\
42\end{array}$ & $\begin{array}{l}20.8 \\
19.9 \\
20.0 \\
19.7 \\
19.4 \\
19.4 \\
19.4 \\
18.9 \\
18.9 \\
19.0 \\
18.8 \\
18.7 \\
18.8 \\
18.4 \\
18.1\end{array}$ & $\begin{array}{l}20.2 \\
19.8 \\
19.0 \\
19.2 \\
19.1 \\
13.7 \\
18.6 \\
18.4 \\
18.4 \\
18.6 \\
18.9 \\
18.4 \\
18.5 \\
18.0 \\
18.0\end{array}$ & $\begin{array}{l}19.5 \\
19.3 \\
18.9 \\
18.8 \\
18.8 \\
18.5 \\
18.3 \\
18.5 \\
18.1 \\
18.0 \\
18.3 \\
17.9 \\
17.9 \\
17.8 \\
17.6\end{array}$ & $\begin{array}{l}19.7 \\
19.2 \\
18.9 \\
19.2 \\
18.9 \\
18.6 \\
18.4 \\
18.3 \\
18.4 \\
18.4 \\
18.1 \\
18.0 \\
18.0 \\
17.8 \\
17.6\end{array}$ & $\begin{array}{l}19.5 \\
19.2 \\
18.8 \\
19.0 \\
18.8 \\
18.8 \\
18.5 \\
18.4 \\
18.0 \\
18.1 \\
17.8 \\
18.0 \\
18.0 \\
17.7 \\
17.5\end{array}$ & $\begin{array}{l}18.9 \\
19.0 \\
19.0 \\
18.8 \\
18.7 \\
18.7 \\
18.5 \\
18.3 \\
18.2 \\
18.2 \\
18.1 \\
18.0 \\
17.8 \\
17.7 \\
17.3\end{array}$ & $\begin{array}{l}19.8 \\
19.2 \\
18.8 \\
19.0 \\
18.7 \\
18.3 \\
18.6 \\
18.4 \\
18.3 \\
18.1 \\
18.2 \\
18.1 \\
17.9 \\
18.0 \\
17.2\end{array}$ & $\begin{array}{l}19.6 \\
19.0 \\
19.1 \\
18.7 \\
18.7 \\
18.5 \\
18.3 \\
18.2 \\
18.1 \\
18.1 \\
18.2 \\
18.3 \\
17.7 \\
17.7 \\
17.5\end{array}$ & $\begin{array}{l}20.0 \\
19.1 \\
19.4 \\
19.0 \\
19.1 \\
18.8 \\
18.8 \\
18.8 \\
18.9 \\
18.8 \\
18.9 \\
18.4 \\
18.1 \\
18.3 \\
17.9\end{array}$ & $\begin{array}{l}20.3 \\
19.9 \\
19.6 \\
19.8 \\
19.5 \\
19.6 \\
19.3 \\
19.2 \\
19.5 \\
19.1 \\
19.0 \\
19.3 \\
19.1 \\
18.7 \\
18.5\end{array}$ & $\begin{array}{l}21.5 \\
20.6 \\
20.6 \\
20.3 \\
20.3 \\
20.2 \\
20.1 \\
19.6 \\
19.5 \\
19.8 \\
19.9 \\
19.8 \\
19.7 \\
19.5 \\
19.0\end{array}$ & $\begin{array}{l}20.9 \\
20.0 \\
20.0 \\
19.7 \\
19.7 \\
19.7 \\
19.5 \\
19.1 \\
19.0 \\
19.2 \\
19.3 \\
19.2 \\
19.1 \\
19.0 \\
18.4\end{array}$ \\
\hline
\end{tabular}


Table D-VI: Soll Moisture During Second Field Season

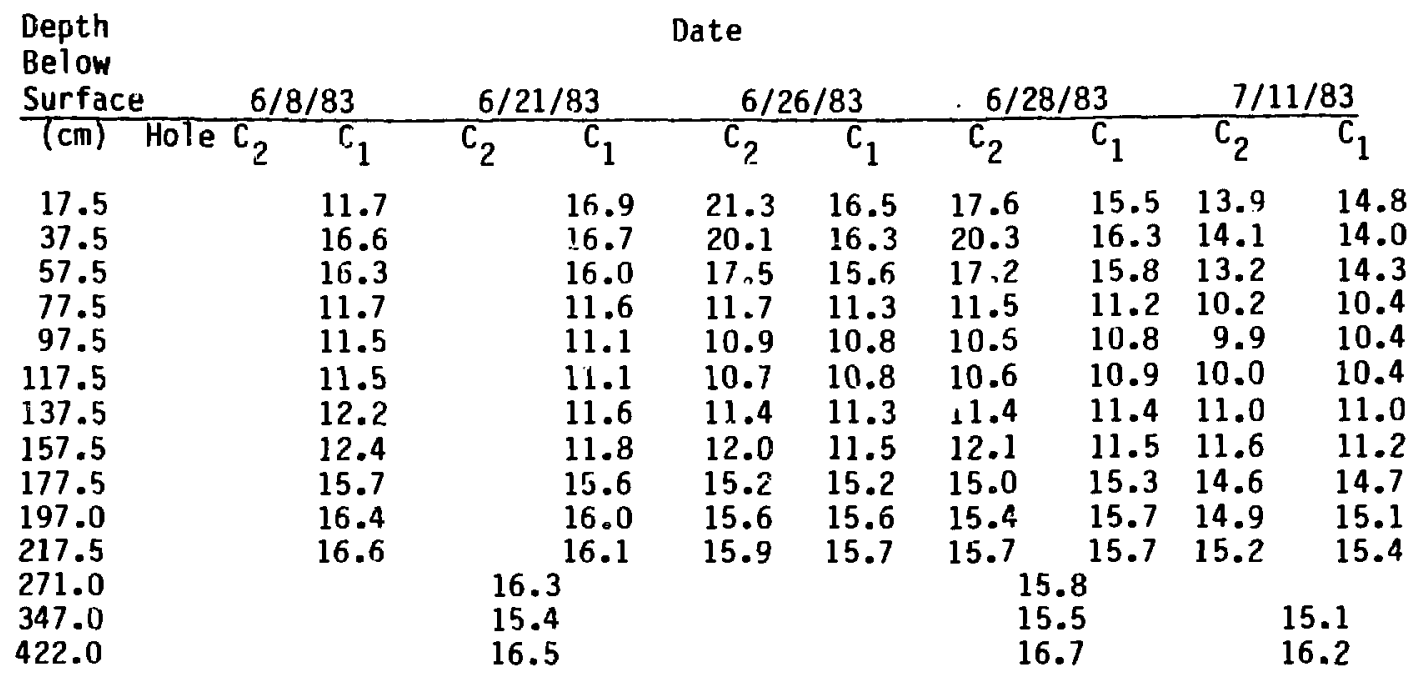

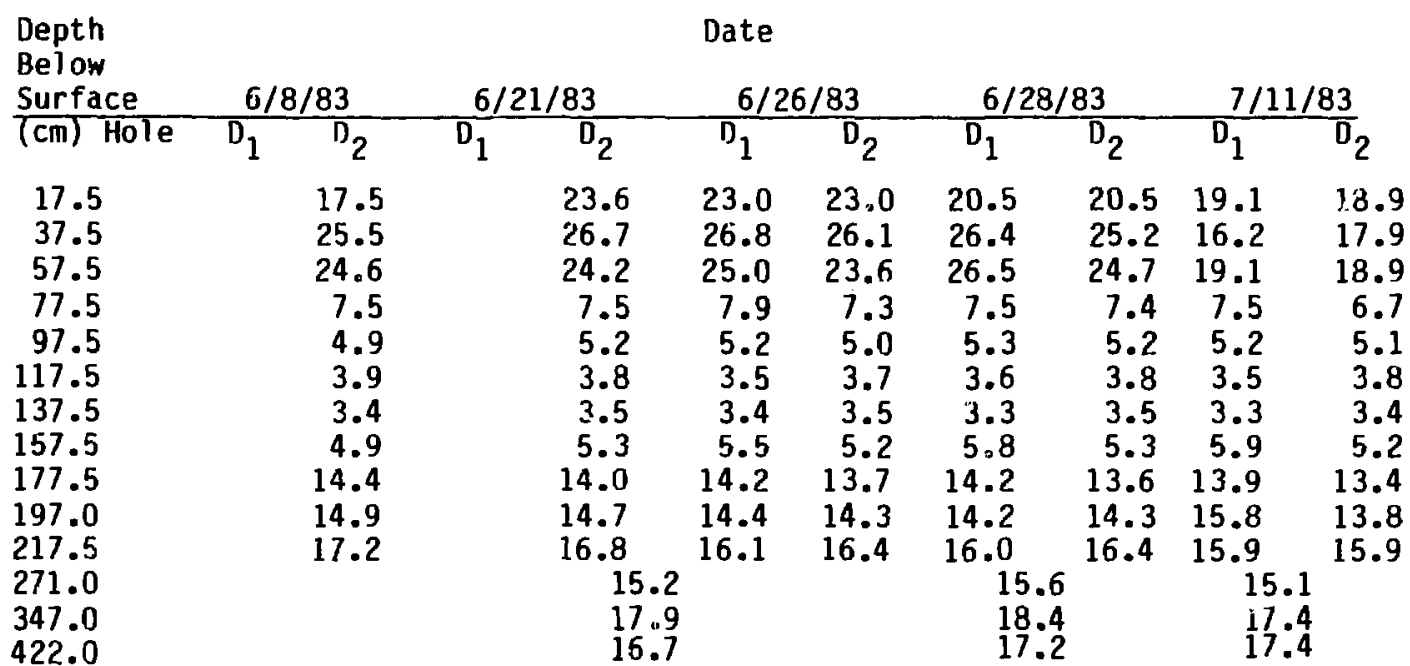

*Center hole given first. 
Table D-VI (cont)

Depth

Date

Bel ow

Date

(cm) HoT

$7 / 28 / 83$ $8 / 24 / 83$

$9 / 14 / 83$
$9 / 20: 83$

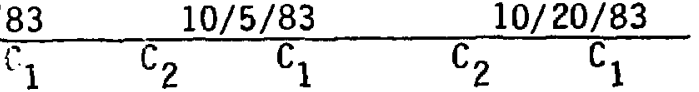

17.5 $\begin{array}{llllll}23.6 & 22.2 & 27.9 & 24.0 & 28.4 & 25.8\end{array}$

37.5

57.5

77.5

97.5

117.5

137.5

157.5

177.5

197.0

217.5

271.0

347.0

422.0

$\begin{array}{llllll}23.0 & 23.0 & 27.7 & 20.3 & 28.9 & 25.6\end{array}$

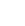

$\begin{array}{llll}16.5 & 20.5 & 21.2 & 16.7\end{array}$

23.821 .3

$\begin{array}{llllll}28.5 & 23.8 & 26.5 & 23.5 & 23.0 & 21.2\end{array}$

$\begin{array}{llllll}12.7 & 14.4 & 14.8 & 15.2 & 15.2 & 14.8\end{array}$

$\begin{array}{llll}11.2 & 12.9 & 13.2 & 15.2\end{array}$

$13.9 \quad 1.4 .9$

$\begin{array}{lllll}13.2 & 13.7 & 11.6 & 11.5\end{array}$

$9.8 \quad 10.4$

$\begin{array}{llllll}10.9 & 12.0 & 12.8 & 15.1 & 13.7 & 14.6\end{array}$

$\begin{array}{llllll}11.4 & 12.0 & 14.0 & 15.6 & 14.9 & 15.7\end{array}$

$11.9 \quad 11.8$

14.2

15.2

$15.1 \quad 15.9$

$14.6 \quad 14.8$

$17.6 \quad 19.0$

$19.0 \quad 20.8$

$15.0 \quad 15.5$

17.7

18.7

$19.1 \quad 20.4$

$15.2 \quad 15.5$

$18.6 \quad 19.2$

$20.2 \quad 21.5$

21.2

18.0

18.3

$\begin{array}{llllll}14.6 & 15.1 & 13.1 & 13.4 & 12.1 & 11.7\end{array}$

$\begin{array}{llllll}20.0 & 20.4 & 17.1 & 17.5 & 15.9 & 16.3\end{array}$

22.1
19.3
20.0

$19 \cdot 4$

17.4

17.4

Depth

Date

Below

Surface (cm) HoTe

17.5
37.5
57.5
77.5
97.5
117.5
137.5
157.5
177.5
197.0
217.5
271.0
347.0
422.0

$7 / 28 / 83 \quad 8 / 24 / 83 \quad 9 / 14 / 83$

$\begin{array}{rrrrrr}9 / 20 / 83 & & 10 / 5 / 83 & & 10 / 20 / 83 \\ \mathrm{D}_{1} & \mathrm{D}_{2} & \mathrm{D}_{1} & \mathrm{D}_{2} & \mathrm{D}_{1} & \mathrm{D}_{2}\end{array}$

\section{$\begin{array}{llll}10.0 & 15.7 & 26.0 & 16.3\end{array}$ \\ $27.9 \quad 24.2$}

$\begin{array}{llll}16.1 & 14.8 & 28.1 & 15.4\end{array}$

$\begin{array}{llll}16.7 & 16.4 & 22.5 & 14.4\end{array}$

$\begin{array}{llll}8.1 & 8.1 & 7.7 & 6.3\end{array}$

$\begin{array}{llll}6.1 & 6.0 & 4.9 & 4.8\end{array}$

$\begin{array}{llll}4.8 & 5.0 & 3.6 & 3.8\end{array}$

$\begin{array}{llll}4.5 & 4.6 & 3.4 & 3.5\end{array}$

$\begin{array}{llll}7.1 & 6.5 & 5.9 & 5.9\end{array}$

$\begin{array}{llll}18.0 & 18.4 & 19.6 & 19.2\end{array}$

$\begin{array}{llll}19.4 & 19.4 & 21.5 & 20.3\end{array}$

$\begin{array}{llll}20.8 & 21.9 & 23.6 & 24.0\end{array}$

$32.1 \quad 22.8$

22.

24.

$8.1 \quad 7.2$

$5.0 \quad 4.9$

$3.7 \quad 3.7$

3.43 .4

$6.6 \quad 5.7$

$19.3 \quad 18.4$

$19.5 \quad 19.1$

22.322 .4

24.0

24.4

$\begin{array}{llllll}4.7 & 4.6 & 4.5 & 4.5 & 4.2 & 4.3\end{array}$

$\begin{array}{llllll}5.5 & 5.5 & 6.2 & 5.5 & 5.8 & 5.4\end{array}$

$20.97^{21.2} 17.87^{18.2} 17.0 \frac{1}{17.0}^{17.0}$ 21.7

25.0
25.4

20.6

20.9

20.7
21.0 
Table D-VI (cont)

罖

\begin{tabular}{|c|c|c|c|c|c|c|c|c|c|c|}
\hline \multirow{2}{*}{$\begin{array}{l}\text { Depth } \\
\text { Below } \\
\text { Surface } \\
(\mathrm{cm}) \text { Hole }\end{array}$} & \multicolumn{10}{|c|}{ Date } \\
\hline & $\mathrm{C}_{2}$ & $\mathrm{C}_{1}$ & $\mathrm{C}_{2}$ & $\mathrm{C}_{1}$ & $\mathrm{C}_{2}$ & $\mathrm{C}_{1}$ & $\mathrm{C}_{2}$ & $\mathrm{C}_{1}$ & $\mathrm{C}_{2}$ & $C_{1}$ \\
\hline $\begin{array}{r}17.5 \\
37.5 \\
57.5 \\
77.5 \\
97.5 \\
117.5 \\
137.5 \\
157.5 \\
177.5 \\
197.0 \\
217.5 \\
271.0 \\
347.0 \\
422.0\end{array}$ & $\begin{array}{r}20.8 \\
22.1 \\
16.9 \\
9.7 \\
9.2 \\
9.6 \\
10.6 \\
11.5 \\
14.9 \\
15.5 \\
15.7 \\
1 \\
15 \\
18\end{array}$ & $\begin{array}{r}19.6 \\
20.9 \\
15.7 \\
9.5 \\
9.6 \\
10.2 \\
10.9 \\
11.5 \\
14.7 \\
16.1 \\
15.8 \\
.7\end{array}$ & $\begin{array}{r}18.0 \\
17.7 \\
13.0 \\
7.9 \\
7.5 \\
8.2 \\
9.3 \\
10.5 \\
13.3 \\
14.0 \\
14.2\end{array}$ & $\begin{array}{r}17.6 \\
18.2 \\
14.7 \\
8.1 \\
8.1 \\
8.9 \\
9.8 \\
10.1 \\
13.8 \\
14.4 \\
14.5 \\
.4\end{array}$ & $\begin{array}{r}17.9 \\
16.9 \\
12.3 \\
7.5 \\
7.2 \\
7.8 \\
9.1 \\
10.2 \\
13.2 \\
13.0 \\
13.1\end{array}$ & $\begin{array}{r}17.3 \\
17.2 \\
13.7 \\
7.9 \\
7.9 \\
8.4 \\
9.0 \\
9.4 \\
12.8 \\
13.7 \\
13.7\end{array}$ & $\begin{array}{r}24.9 \\
18.5 \\
13.4 \\
7.8 \\
7.7 \\
8.2 \\
9.0 \\
10.0 \\
12.6 \\
13.7 \\
13.5\end{array}$ & $\begin{array}{r}23.7 \\
18.2 \\
14.7 \\
8.4 \\
8.2 \\
8.6 \\
9.4 \\
9.4 \\
13.5 \\
14.0 \\
13.9 \\
.1 \\
.8 \\
.3\end{array}$ & $\begin{array}{r}27.1 \\
19.4 \\
13.7 \\
8.2 \\
8.2 \\
8.3 \\
9.0 \\
9.8 \\
13.3 \\
13.8 \\
13.3\end{array}$ & $\begin{array}{r}25.4 \\
18.8 \\
14.4 \\
8.6 \\
8.5 \\
8.9 \\
9.3 \\
10.0 \\
13.6 \\
14.1 \\
14.0 \\
1 \\
4 \\
.6\end{array}$ \\
\hline
\end{tabular}

Depth

Date

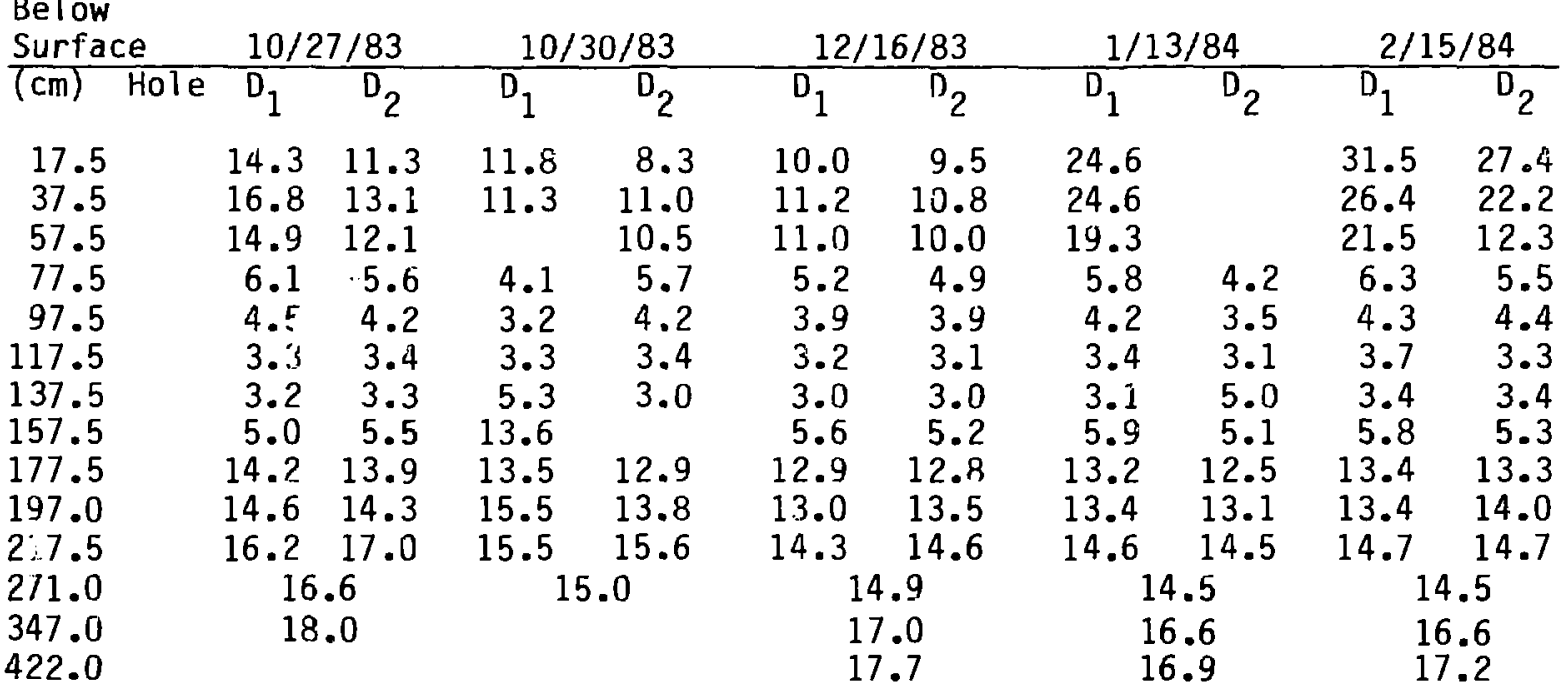


APPENDIX E

Backyround Data 
TABLE E-I

BACKGROUND CONCENTRATIONS IN OUTFLOW FROM CAISSONS NOT CONTAINING TRACER

$\begin{array}{ccccc}\text { Sample } & \text { Co (pp) } & \text { Sr (ppm) } & \text { Cs (ppb) } & \text { Cl (ppm) } \\ 1 & <20 & 0.35 \pm 0.02 & <5.0 & - \\ 2 & <1.0 & 0.079 \pm 0.0009 & <0.2 & - \\ 3 & - & 0.096 \pm 0.003 & - & - \\ 4 & - & 0.098 \pm 0.003 & - & - \\ 5-10 & - & - & - & 44-49\end{array}$

TABLE E-II

$\mathrm{Sr}, \mathrm{Co}, \mathrm{Cs}$ IN SUPPLEMENTAL WATER

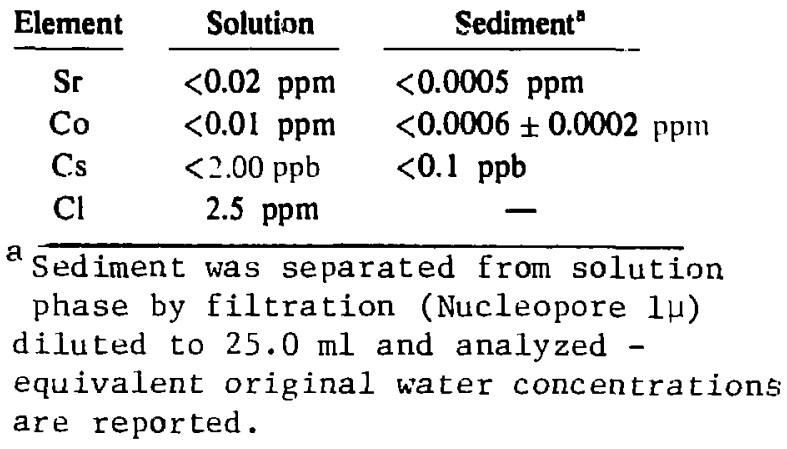




\section{TABLE C-VI}

Caisson D Horizontal Profiles \& Volumetric Moisture

$197 \mathrm{~cm}$ below surface

distance from center $(\mathrm{cm})$

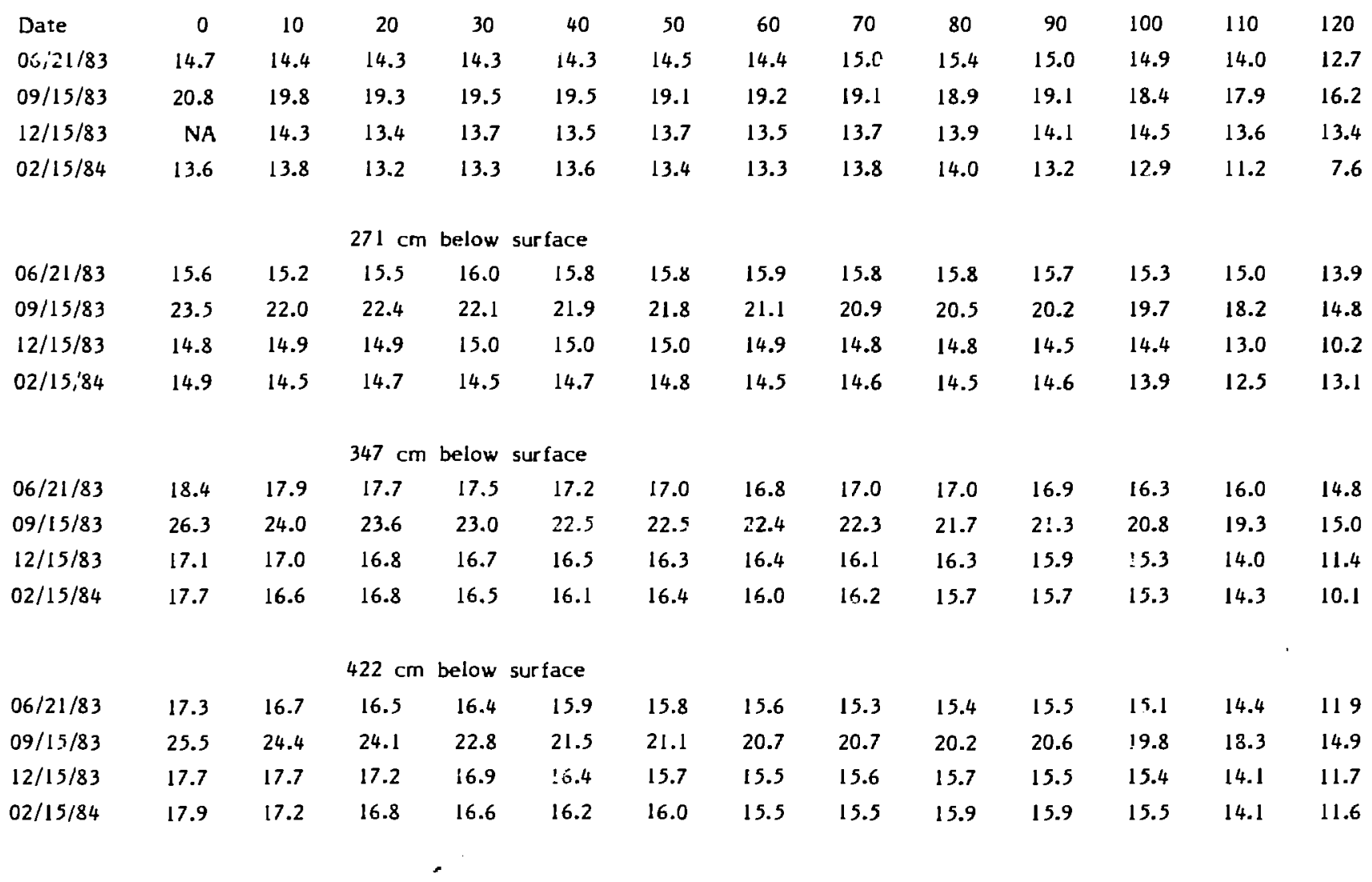


TABLE E-III

NATURALLY OCCURRING LEVELS OF Co, Sr, and Cs IN TUFF USED IN CAISSON FILL

\begin{tabular}{|c|c|c|c|}
\hline Sample & Sr (ppm) & Co (ppm) & Cs (ppm) \\
\hline 1 & $31.2 \pm 6.3$ & $1.81 \pm 0.19$ & $2.68 \pm 0.27$ \\
\hline 2 & $28.3 \pm 5.8$ & $1.22 \pm 0.15$ & $2.41 \pm 0.25$ \\
\hline 3 & $26.5 \pm 6.2$ & $1.35 \pm 0.16$ & $2.52 \pm 0.26$ \\
\hline 4 & $27.9 \pm 6.1$ & $0.72 \pm 0.09$ & $2.41 \pm 0.24$ \\
\hline 5 & $20.9 \pm 5.4$ & $0.48 \pm 0.07$ & $2.54 \pm 0.26$ \\
\hline 6 & $7.2 \pm 6.3$ & $1.13 \pm 0.14$ & $2.31 \pm 0.24$ \\
\hline 7 & $19.1 \pm 4.5$ & $0.2 \mathrm{I} \pm 0.07$ & $2.85 \pm 0.29$ \\
\hline 8 & $24.6 \pm 6.1$ & $0.83 \pm 0.11$ & $2.55 \pm 0.27$ \\
\hline 9 & $36.2 \pm 5.9$ & $0.48 \pm 0.07$ & $2.59 \pm 0.26$ \\
\hline 10 & $27.0 \pm 5.9$ & $1.56 \pm 0.18$ & $2.41 \pm 0.25$ \\
\hline 11 & $18.0 \pm 4.6$ & $0.03 \pm 0.07$ & $2.33 \pm 0.24$ \\
\hline 12 & $17.8 \pm 5.0$ & $0.77 \pm 0.11$ & $2.39 \pm 0.25$ \\
\hline 13 & $18.1 \pm 4.3$ & $0.29 \pm 0.07$ & $2.40 \pm 0.25$ \\
\hline 14 & $16.3 \pm 4.3$ & $1.23 \pm 0.16$ & $2.76 \pm 0.30$ \\
\hline 15 & $24.5 \pm 5.6$ & $0.13 \pm 0.09$ & $2.62 \pm 0.28$ \\
\hline 16 & $27.5 \pm 6.0$ & $1.14 \pm 0.16$ & $2.48 \pm 0.26$ \\
\hline 17 & $20.8 \pm 4.6$ & $0.48 \pm 0.08$ & $2.23 \pm 0.23$ \\
\hline 18 & $27.8 \pm 5.2$ & $0.29 \pm 0.06$ & $2.59 \pm 0.26$ \\
\hline 19 & $21.7 \pm 4.8$ & $0.20 \pm 0.07$ & $2.83 \pm 0.29$ \\
\hline 20 & $36.7 \pm 6.6$ & $0.25 \pm 0.08$ & $2.57 \pm 0.27$ \\
\hline 21 & $29.3 \pm 6.7$ & $0.85 \pm 0.12$ & $2.64 \pm 0.27$ \\
\hline 22 & $33.1 \pm 6.4$ & $1.05 \pm 0.15$ & $2.44 \pm 0.26$ \\
\hline 23 & $28.1 \pm 6.2$ & $0.19 \pm 0.08$ & $2.48 \pm 0.26$ \\
\hline 24 & $18.8 \pm 6.8$ & $0.80 \pm 0.12$ & $2.45 \pm 0.25$ \\
\hline 25 & $19.8 \pm 5.4$ & $0.41 \pm 0.06$ & $2.25 \pm 0.23$ \\
\hline 26 & $28.7 \pm 6.1$ & $0.94 \pm 0.12$ & $2.31 \pm 0.24$ \\
\hline
\end{tabular}


APPENDIX $F$

Tracer Concentrations in Uutflow 
Sr OUTFLOW CONCENTRATIONS AS A FUNCTION OF TIME IN CAISSON C (pPm) (Tuff only)

\begin{tabular}{|c|c|c|c|}
\hline Date & Result & \\
\hline Sept & & Nor & \\
\hline 26 & .20 & 1 & 1.04 \\
\hline 26 & 16.00 & 2 & 1.00 \\
\hline 27 & 25.70 & 3 & .97 \\
\hline 27 & 451.00 & 4 & .89 \\
\hline 28 & 1.02 & 7 & 1.03 \\
\hline 28 & 1.17 & 8 & 1.03 \\
\hline 29 & 279.20 & 9 & .83 \\
\hline 30 & $2.8 j$ & 10 & .89 \\
\hline \multirow{2}{*}{\multicolumn{2}{|c|}{ October }} & 14 & 1.02 \\
\hline 1 & & 16 & .79 \\
\hline $\begin{array}{l}1 \\
2\end{array}$ & 1.30 & 23 & .85 \\
\hline $\begin{array}{l}2 \\
3\end{array}$ & 2.33 & 28 & .69 \\
\hline $\begin{array}{l}3 \\
3\end{array}$ & 185.50 & & \\
\hline $\begin{array}{l}3 \\
4\end{array}$ & 1.26 & \multicolumn{2}{|c|}{ December } \\
\hline 4 & 1.24 & 2 & .73 \\
\hline 4 & 1.29 & 9 & .70 \\
\hline 5 & 1.27 & 15 & .82 \\
\hline 5 & 1.28 & 20 & .75 \\
\hline 6 & 1.26 & 22 & .77 \\
\hline 6 & 1.21 & 27 & 1.25 \\
\hline 7 & 4.30 & 29 & .70 \\
\hline 7 & 20.67 & \multirow{2}{*}{\multicolumn{2}{|c|}{ January }} \\
\hline 8 & 1.30 & & \\
\hline 9 & 1.27 & 4 & .71 \\
\hline 10 & 1.34 & 10 & .65 \\
\hline 11 & 1.34 & 12 & .78 \\
\hline 13 & 1.17 & 17 & 1.04 \\
\hline 14 & 1.15 & 24 & .80 \\
\hline 15 & 1.04 & 26 & .70 \\
\hline 16 & .97 & 31 & .65 \\
\hline 17 & .96 & \multicolumn{2}{|c|}{ February } \\
\hline 18 & 1.07 & 2 & .72 \\
\hline 20 & .98 & 7 & .76 \\
\hline 24 & 1.02 & 9 & .73 \\
\hline 25 & .91 & 9 & נו. \\
\hline 26 & .99 & & \\
\hline 27 & 1.03 & & \\
\hline 28 & .96 & & \\
\hline 31 & 1.00 & & \\
\hline
\end{tabular}


TABLE F-II

\section{Sr OUTFLOW CONCENTRATIONS}

AS A FUNCTION OF TIME

IN CAISSON D (biobarrier)

(ppm)

\begin{tabular}{cr} 
Date & Result \\
\hline September & \\
14 & \\
14 & 2.47 \\
14 & 7.04 \\
15 & 16.91 \\
15 & 52.49 \\
15 & 58.20 \\
15 & 65.69 \\
16 & 69.44 \\
16 & 103.46 \\
16 & 107.80 \\
16 & 124.00 \\
17 & 147.67 \\
17 & 257.20 \\
18 & 356.17 \\
18 & 514.00 \\
19 & 591.33 \\
19 & 780.67 \\
20 & 811.33 \\
20 & 1127.17 \\
21 & 1172.50 \\
21 & 1211.67 \\
22 & 1396.67 \\
22 & 1799.80 \\
23 & 2196.00 \\
23 & 2806.00 \\
24 & 2966.00 \\
24 & 3237.00 \\
25 & 3070.00 \\
25 & 3570.00 \\
26 & 3692.00 \\
26 & 4247.00 \\
27 & 4596.00 \\
27 & 4546.00 \\
28 & 4593.00 \\
28 & 5434.00 \\
29 & 5546.00 \\
30 & 5351.00 \\
& 5019.00
\end{tabular}

October:

5302.00

5264.00

$3 \quad 5265.00$

$3 \quad 5397.00$

$4 \quad 5660.00$

$4 \quad 5851.00$

$5 \quad 5975.00$

$5 \quad 6057.00$

$6 \quad 6070.00$

$6 \quad 5480.00$

$7 \quad 5740.00$

$7 \quad 5830.00$

$8 \quad 5530.00$

$9 \quad 5890.00$

$10 \quad 5800.00$

$11 \quad 5660.00$

$13 \quad 5490.00$

$14 \quad 5550.00$

$15 \quad 5550.00$

$16 \quad 5480.00$

$17 \quad 5400.00$

$18 \quad 4670.00$

$20 \quad 4600.00$

$24 \quad 4640.00$

$25 \quad 4680.00$

$26 \quad 4600.00$

$27 \quad 4650.00$

$28 \quad 4520.00$

$31 \quad 4440.00$ 
TABLE F-II (cont)

\section{November}

4410.00

4360.00

3940.00

3980.00

3810.00

3900.00

3980.00

4080.00

4210.00

3385.00

3370.00

3445.00

$\begin{array}{cc}\text { January } & \\ 4 & 2945.00 \\ 10 & 2985.00 \\ 12 & 2815.00 \\ 17 & 3075.00 \\ 26 & 3255.00 \\ 26 & 3170.00 \\ 31 & 2750.00\end{array}$

\section{February}

16

2

7

2880.00

2830.00

$9 \quad 2800.00$

\section{December}

$\begin{array}{rr}2 & 3445.00 \\ 9 & 3555.00 \\ 15 & 3540.00 \\ 20 & 3415.00 \\ 22 & 3575.00 \\ 27 & 3270.00 \\ 29 & 3765.00\end{array}$


Co OUTFLOW CONCENTRATIONS

AS A FUNCTION OF TIME IN

CAISSON D (biobarrier)

(ppm)

\begin{tabular}{|c|c|c|c|}
\hline Date & Result $^{a}$ & & \\
\hline Septe & & Dec & \\
\hline 14 & $<0.01$ & 2 & $0.23 \pm 0.04$ \\
\hline 16 & $<0.01$ & 5 & $0.21 \pm 0.04$ \\
\hline 19 & $<0.01$ & 7 & $0.20 \pm 0.04$ \\
\hline 23 & $<0.01$ & 9 & $0.21 \pm 0.04$ \\
\hline 27 & $<0.01$ & 13 & $0.22 \pm 0.04$ \\
\hline Octo & & 15 & $0.12 \pm 0.01$ \\
\hline 1 & $<0.01$ & 20 & $0.12 \pm 0.01$ \\
\hline 5 & $<0.01$ & 22 & $0.12 \pm 0.01$ \\
\hline 9 & $<0.01$ & 27 & $0.13 \pm 0.01$ \\
\hline 13 & $<0.01$ & 29 & $0.13 \pm 0.0$ \\
\hline 16 & $<0.01$ & Jan & \\
\hline 20 & $<0.01$ & 4 & $<0.02$ \\
\hline 24 & $<0.01$ & 10 & $<0.02$ \\
\hline 27 & 20.01 & 12 & $<0.02$ \\
\hline Nove & & 17 & $0.01 \pm 0.01$ \\
\hline 1 & $<0.01$ & 24 & $0.02 \pm 0.02$ \\
\hline 4 & $<0.01$ & 26 & $<0.02$ \\
\hline 9 & $<0.01$ & 31 & $<0.02$ \\
\hline 14 & $<0.01$ & & \\
\hline 18 & $<0.01$ & & \\
\hline 23 & $0.04 \pm 0.01$ & & \\
\hline 28 & $0.03 \pm 0.01$ & & \\
\hline 30 & $0.02 \pm 0.01$ & & \\
\hline
\end{tabular}




\section{OUTFLOW CONCENTRATIONS \\ AS A FUNCTION OF TIME IN \\ CAISSON C \\ (ppm)}

\begin{tabular}{lccc} 
Date & Result & December & \\
\cline { 2 - 3 } September & & 2 & 544.00 \\
26 & 181.00 & 5 & 480.00 \\
27 & 276.00 & 7 & 480.00 \\
28 & 411.00 & 9 & 470.00 \\
Gctober & & 13 & 480.00 \\
1 & 450.00 & 15 & 470.00 \\
4 & 489.00 & 20 & 534.00 \\
7 & 500.00 & 22 & 540.30 \\
10 & 530.00 & 27 & 493.00 \\
13 & 530.00 & 29 & 535.50 \\
15 & 530.00 & & \\
18 & 530.00 & January & \\
20 & 530.00 & 4 & 504.00 \\
25 & 530.00 & 10 & 498.00 \\
28 & 520.00 & 12 & 466.00 \\
& & 17 & 466.00 \\
November & 550.00 & 24 & 580.20 \\
1 & 540.00 & 26 & 660.20 \\
4 & 540.00 & $3 i$ & 458.00 \\
7 & 540.00 & February & \\
10 & 550.00 & 21 & 566.00 \\
14 & 520.00 & 23 & 562.00 \\
16 & 530.00 & & \\
18 & 520.00 & March & \\
23 & 504.00 & 1 & 554.00 \\
28 & 504.00 & 6 & 580.00 \\
30 & & &
\end{tabular}




\section{OUTFLOW CONCENTRATIONS AS A FUNCTION OF TIME IN CAISSON D}

\begin{tabular}{|c|c|c|c|}
\hline Date & Result & \\
\hline \multicolumn{2}{|c|}{ September } & \multicolumn{2}{|c|}{ December } \\
\hline 14 & 397.00 & 2 & $3: 1.00$ \\
\hline 16 & 392.00 & 5 & 298.00 \\
\hline 20 & 400.00 & 7 & 284.00 \\
\hline 23 & 385.00 & 9 & 288.00 \\
\hline 26 & 358.00 & 13 & 28700 \\
\hline \multirow{2}{*}{28} & 373.00 & 15 & 286.00 \\
\hline & & 20 & 340.00 \\
\hline \multicolumn{2}{|c|}{ October } & 22 & 330.00 \\
\hline $\begin{array}{l}1 \\
3\end{array}$ & $\begin{array}{l}349.00 \\
347.00\end{array}$ & 27 & 305.00 \\
\hline $\begin{array}{l}3 \\
6\end{array}$ & $\begin{array}{l}347.00 \\
34500\end{array}$ & 29 & 320.00 \\
\hline $\begin{array}{l}6 \\
9\end{array}$ & $\begin{array}{l}345.00 \\
338.00\end{array}$ & \multicolumn{2}{|c|}{ January } \\
\hline 10 & 338.00 & 4 & 273.00 \\
\hline 11 & 338.00 & 12 & 272.00 \\
\hline 13 & 376.00 & 17 & 272.00 \\
\hline 17 & 364.00 & 24 & 320.00 \\
\hline 20 & 357.00 & 26 & 292.00 \\
\hline 24 & 348.00 & 31 & 263.00 \\
\hline 27 & 352.00 & \multicolumn{2}{|c|}{ February } \\
\hline \multicolumn{2}{|c|}{ November } & 21 & 310.00 \\
\hline 1 & 351.00 & 23 & 310.00 \\
\hline 4 & 354.00 & 28 & 310.00 \\
\hline 7 & 362.00 & \multirow{2}{*}{\multicolumn{2}{|c|}{ March }} \\
\hline 10 & 354.00 & & \\
\hline 14 & 362.00 & 1 & 296.00 \\
\hline 16 & 368.00 & 6 & 293.00 \\
\hline 18 & 359.00 & & \\
\hline 23 & 330.00 & & \\
\hline 28 & 316.00 & & \\
\hline 30 & 309.00 & & \\
\hline
\end{tabular}

